\title{
Behavioural changes in urban mobility in Barcelona due to the COVID-19 pandemic and its impact on air pollution and greenhouse gas emissions
}

\begin{abstract}
This study assesses changes in mobility behaviour in the City of Barcelona due the COVID-19 pandemic and its impact on air pollution and GHG emissions. Urban transport is an important source of global greenhouse gas (GHG) emissions. Improving urban mobility patterns is therefore crucial for mitigating climate change. This study combines quantitative survey data and official government data with in-depth interviews with public administration officials of the City. Data illustrates that Barcelona has experienced an unprecedented reduction in mobility during the lockdown (a $90 \%$ drop) and mobility remained at comparatively low levels throughout the year 2020. Most remarkable is the decrease in the use of public transport in 2020 compared to pre-pandemic levels, whereas road traffic has decreased to a lesser extent and cycling surged at times to levels up to $60 \%$ higher than pre-pandemic levels. These changes in mobility have led to a radical and historic reduction in air pollution, with $\mathrm{NO} 2$ and PM10 concentration complying with WHO guidelines in 2020. Reductions in GHG emissions for Barcelona's transport sector are estimated at almost 250.000 t CO2eq in 2020 (7\% of the City's overall annual emissions). The study derives policy implications aimed at achieving a long-term shift towards climate-friendlier, low-emission transport in Barcelona, namely how to recover lost demand in public transport and seize the opportunity that the crisis brings for reform by further reducing road traffic and establishing a 'cycling culture' in Barcelona, as already achieved in other European cities.
\end{abstract}

Acknowledgments: I would like to thank Adrià Gomila (Director of Mobility at the City Council of Barcelona), Lluis Alegre (Director of Mobility at Autoritat del Transport Metropolita (ATM)), and Xavier Sanyer (Head of the Mobility Service at ATM) for taking time for the interviews and their valuable insights. I would like to thank Roberto de Rios (City Council of Barcelona), Sergi Delgado Treviño (Energy Agency of Barcelona) and Sergi Martínez-Abarca Espelt (ATM) and Nicolau Sentis for providing me with data and guidance on the data. I am also thankful for all the participants of the survey. Finally, I am grateful to Prof. Antoni Carneros, Dr. Alexander Krauss, Johanna Gaudian, Elisa Scocco and Xavier Codina for their thoughtful comments on the questionnaire and the study. 
Universidad de Barcelona

Behavioural changes in urban mobility in Barcelona due to the COVID-19 pandemic and its impact on air pollution and greenhouse gas emissions

Corinna Peters

\section{Contents}

Abbreviations

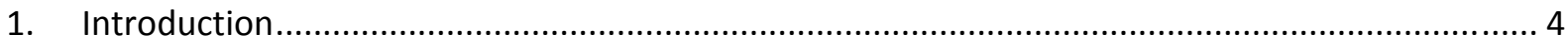

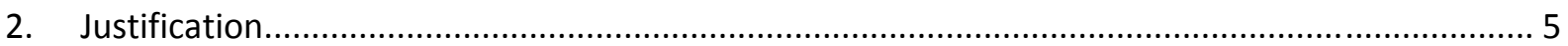

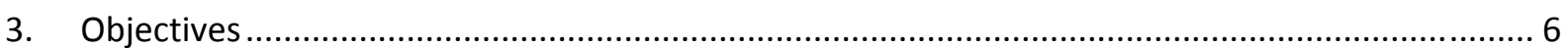

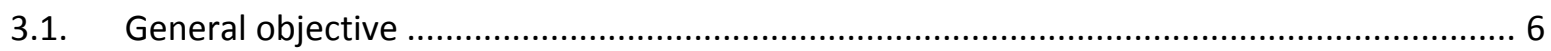

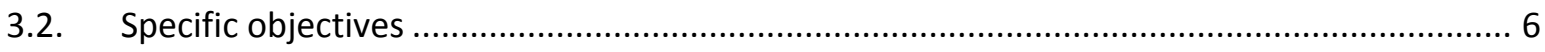

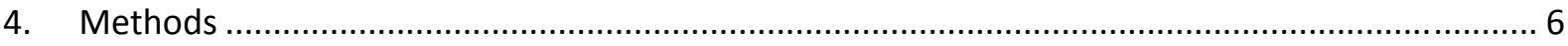

4.1. Government data on use of transport in Barcelona ........................................................... 7

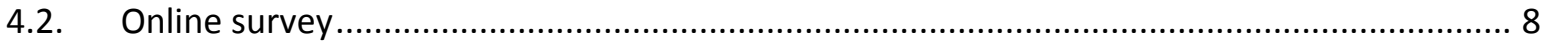

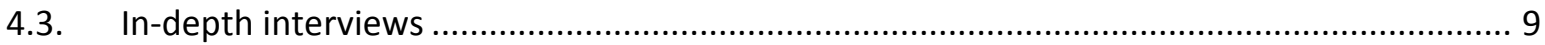

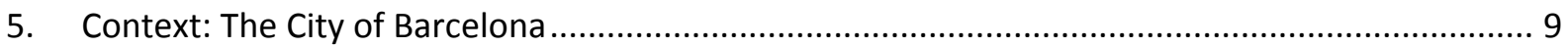

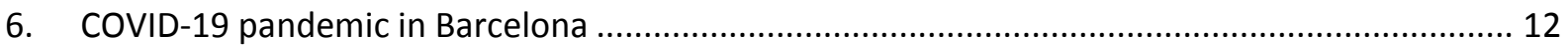

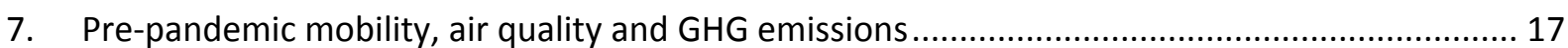

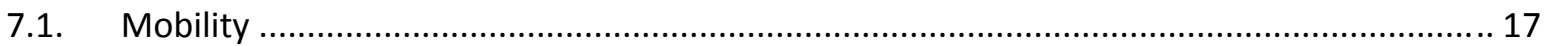

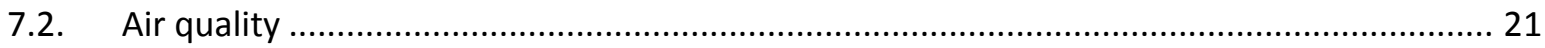

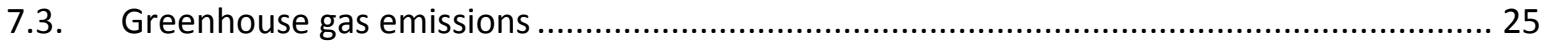

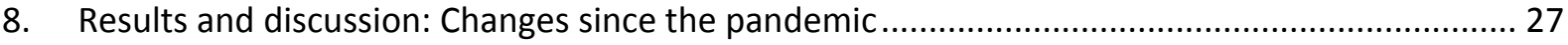

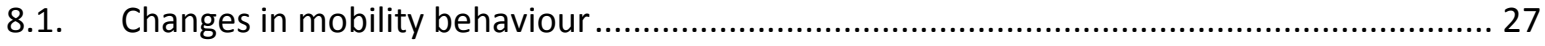

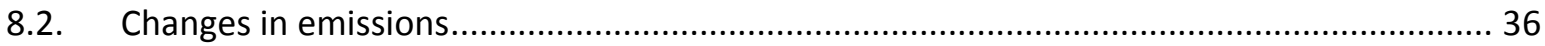

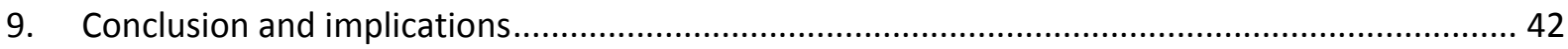

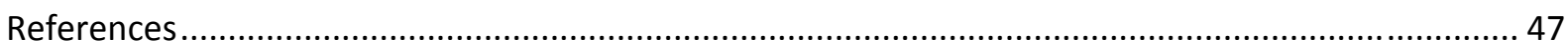

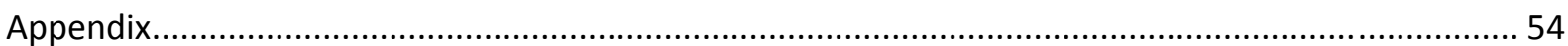

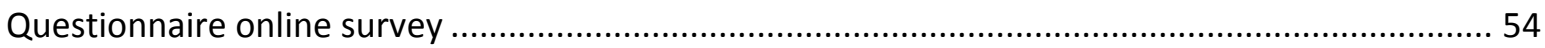

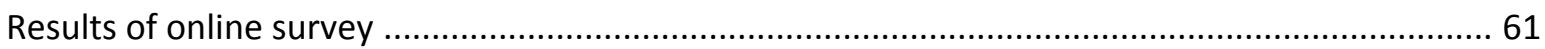

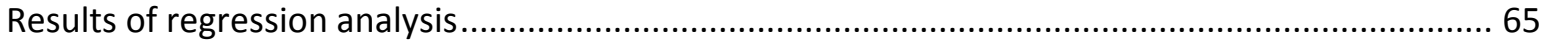

Interview questionnaire for public administration officials of Barcelona........................................ 67

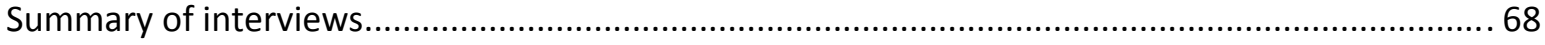

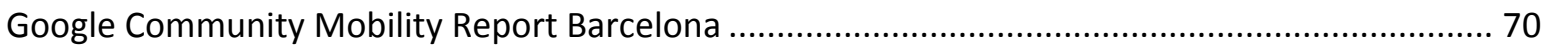


Behavioural changes in urban mobility in Barcelona due to the COVID-19 pandemic and its impact on air pollution and greenhouse gas emissions

\section{Abbreviations}

\begin{tabular}{|l|l|}
\hline ATM & Autoritat del Transport Metropolità de Barcelona (Barcelona's transport authority) \\
\hline BCN & Barcelona \\
\hline CO2eq & Carbon dioxide equivalent \\
\hline EC & European Commission \\
\hline EMEF & Enquesta de Mobilitat en Dia Feiner (mobility survey on weekdays) \\
\hline EU & European Union \\
\hline GHG & Greenhouse gas \\
\hline IEA & International Energy Agency \\
\hline NO2 & Nitrogen dioxide \\
\hline O3 & Ozone \\
\hline PM10 & Particulate matter with an aerodynamic diameter of 10 $\mu \mathrm{m}$ \\
\hline t & Tons \\
\hline WHO & World Health Organisation \\
\hline$\mu g$ & Microgram \\
\hline
\end{tabular}


Universidad de Barcelona

Behavioural changes in urban mobility in Barcelona due to the COVID-19 pandemic and its impact on air pollution and greenhouse gas emissions

Corinna Peters

\section{Introduction}

The present study assesses changes in transport behaviour in the City of Barcelona due to the COVID19 pandemic. It estimates the impact of the changes on the city's greenhouse gas (GHG) emissions and air quality and draws implications from the changes in order to promote a long-term shift towards climate-friendlier urban mobility.

Climate change is one of the major global challenges that our and future generations face. Most governments have committed to contributing to climate change mitigation (e.g. through the Paris Agreement), developed climate change policies and integrated mitigation aspects into different sectoral policies. Cities play a crucial role in contributing to national efforts aimed at fulfilling international climate commitments. Cities are estimated to be responsible for more than $70 \%$ of global GHG emissions (Bednar-Friedl et al., 2015). Due to continued urbanization, higher income levels and increased use of private vehicles, emissions of urban centres have been growing in the past years and are likely to keep rising (ibid).

Urban mobility is an important source of cities' GHG emissions with individual motorized vehicles being the main cause (ibid; Seto et al., 2014). To create more climate-friendly cities, changing our mode of transport is key. Changing mobility patterns also has a major impact on everyday life of the city's population. Getting from one location to another fulfils a vital need for citizens, whether access to employment, schools or services. Changes in transport can imply changes in accessibility and affordability of such services, level of comfort, and time spent in traffic. Global trends in urban mobility show an increase not only in privately owned vehicles, but also a rise in potentially less polluting means of mobility like electric cars as well as an uptake in sharing facilities for bicycles, scooters and cars (Gilibert et al., 2017). These interconnected aspects need to be taken into consideration, when designing urban mobility policies. So far, climate-friendly mobility policies have often aimed at increasing the use of public transport and reducing individual motorized transport, among others (Bednar-Friedl et al., 2015).

Closely linked to urban mobility and the earth's climate is air quality. Many of the drivers of greenhouse gas emissions (e.g. combustion of fossil fuels) are also sources of air pollution (World Health Organization, 2021). In cities within advanced economies, it is mainly emissions from road traffic that pollute the air. Suspended particles, combined with secondary pollutants such as oxides of nitrogen and ozone, have become a major problem in many urban areas around the world posing a severe threat to public health (World Health Organization, 2005). According to the World Health Organization (WHO), ambient air pollution accounts for an estimated 4.2 million deaths per year due to acute and chronic respiratory diseases, lung cancer, heart disease and stroke (World Health Organization, 2021). Due to the link between air pollution and GHG emissions, policies to reduce air pollution can not only lower the burden on public health but also contribute to mitigate climate change (ibid).

In late 2019 and early 2020, the COVID-19 pandemic has struck the world with severe consequences for our behaviour, our means of mobility, the way we work and how we interact with other people. With lockdowns in place in numerous countries, many cities have experienced a drastic reduction in mobility (IEA, 2020a). Cycling and individual motorized transport has gained relative importance and, most notably, citizens in many urban centres have shifted their transport behaviour away from public transport to reduce their risk of contracting and spreading the virus (ibid). The same trends can be 
Behavioural changes in urban mobility in Barcelona due to the COVID-19 pandemic and its impact on air pollution and greenhouse gas emissions

Corinna Peters

observed for mobility in the City of Barcelona (as discussed in the study). The City has taken various measures during the pandemic to promote climate-friendly mobility, e. g. amplifying the available space for cycling and walking and reducing the space for private vehicles (Ajuntament de Barcelona, 2020a). It is unclear how citizens' mobility patterns will develop in the coming months and once the pandemic is under control, but the health crisis also brings a great opportunity for change.

After this introduction, section 2 presents the study's relevance for science, policy and society and the study's main contributions. Section 3 specifies the study's objectives and section 4 discusses the methods used. Section 5 provides an overview of the context, i.e. the City of Barcelona. Section 6 outlines the development of the pandemic in Barcelona and the city's measures to slow the spread of the virus. Section 7 outlines Barcelona's mobility patterns, air quality and GHG emissions before the pandemic. Section 8 presents the results of the study, i.e. mobility patterns, air quality and GHG emission changes since the start of the pandemic, combining multiple data sources. Section 9 concludes and draws policy implications from the analysis.

\section{Justification}

The present study contributes to understanding urban mobility behaviour changes due to the pandemic as well as its effect on air quality and GHG emissions. This is the first study to address this question for the City of Barcelona by integrating government data with survey data and qualitative interviews.

Some research has analysed behavioural patterns in urban mobility. Santos et al. (2013) for example identified factors that influence modal shares in European cities (not including Barcelona). BednarFriedl et al. (2015) shed light on global trends in urban mobility and climate mitigation measures. Gilibert et al. (2017) investigated mobility behaviour in Barcelona focussing on the use of shared mobility services. This research provides important insights into mobility behaviour but was conducted before the COVID-19 pandemic and, in the case of the former two studies, do not provide information for the City of Barcelona.

The pandemic with its tremendous effect on mobility has spurred interest among researchers and political decision-makers alike. The International Energy Agency (IEA) (2020a; 2020b) provides a global overview in the pandemic's impact on urban mobility but does not analyse the reasons for behavioural changes in detail. Other research investigated specific factors influencing changes in mobility behaviour, e.g. the influence of risk perception on travel behaviour during the pandemic in Japan (Parady et al., 2020). Some research has focussed on changes in travel time and destination, but did not study the shift to different modes of transport (Borkowski et al., 2021; Pepe et al., 2020; Chan et al., 2020). The change in modal share during the pandemic has been analysed in various case studies for different cities or countries (Barbieri et al., 2020; Moslem et al., 2020; Bucsky, 2020; Meena, 2020; Pawar et al., 2020), but not for Barcelona.

This present study aims to fill this research gap. It presents publicly available data on mobility in Barcelona for the year 2020 (March - December) and offers a fresh perspective on mobility behaviour in Barcelona during the pandemic with data obtained through an online survey. The study can help understand why commuters chose to change their mobility behaviour. 
Behavioural changes in urban mobility in Barcelona due to the COVID-19 pandemic and its impact on air pollution and greenhouse gas emissions

Corinna Peters

This study also complements existing research studying effects of the pandemic on air quality in Barcelona (Baldasano, 2020; Tobías et al., 2020). While these two studies focus on air pollution changes during the first weeks of the pandemic, this present work analyses air pollution data for the entire year 2020 and compares it to 2019 levels. Thereby, this research adds to the findings of the two studies, analysing pollution levels also later in the year 2020 when the strict lockdown was over, and mobility started to pick up again.

With regard to GHG emissions, there is still limited data available at the city level (Parvez et al., 2019; Intergovernmental Panel on Climate Change, 2015). The annual report of Barcelona's Energy Agency provides an overview of the City's GHG emissions. The latest available data is for the year 2018. The Energy Agency has also estimated GHG emission reductions during the strict lockdown (March to June 2020), but not for the rest of the year (Agència d'Energia de Barcelona, 2020). This present study draws on that data to estimate the GHG emission reduction due to changes in mobility for the entire year 2020 and instead of just focusing on GHG emissions, it analyses behavioural changes as well.

In addition, the study derives implications for decision-makers in Barcelona about transport behaviour and preferences in order to develop measures promoting climate-friendly mobility patterns. Thereby the study contributes not only to the existing scientific literature but also from a societal and practical point of view. To add to the current policy discussion the results of the study will be presented to government officials in the City Council of Barcelona once finalized.

\section{Objectives}

\subsection{General objective}

The study aims to analyse how transport behaviour of Barcelona's citizens has changed during the pandemic, and which lessons learned and policy implications can be drawn from those changes to achieve a long-term shift towards climate-friendlier, low-emission transport.

\subsection{Specific objectives}

In particular, this study aims to:

(i) detect changes in mobility patterns in Barcelona due to the pandemic,

(ii) estimate the impact of those changes on air pollution,

(iii) estimate the impact of those changes on GHG's emissions,

(iv) understand citizens' different preferences for different modes of transport, and

(v) derive policy implications for promoting low emission transport in Barcelona.

\section{Methods}

To achieve these objectives, a q-squared methodology is applied that combines quantitative survey data and official government data together with qualitative interviews. This integrated research 
Behavioural changes in urban mobility in Barcelona due to the COVID-19 pandemic and its impact on air pollution and greenhouse gas emissions

Corinna Peters

approach allows for a broader and more nuanced understanding of the effects brought about by the pandemic.

Data from official sources was analysed, including datasets provided by national and international institutions, and government reports. In addition, an extensive literature review of current research on this topic was conducted. This analysis was complemented with an online survey on transport behaviour of 100 commuters in Barcelona (as outlined in the questionnaire in the Appendix, Questionnaire online survey). Furthermore, semi-structured in-depth interviews with three decisionmakers in Barcelona's administration were conducted, namely with the Director of Mobility at the City Council of Barcelona (Adrià Gomila), the Director of Mobility at Autoritat del Transport Metropolita (ATM) (Lluis Alegre) and the Head of the Mobility Service at ATM (Xavier Sanyer) (as outlined in the guiding questions and summarised in the Appendix, Interview questionnaire for public administration officials of Barcelona, and Summary of interviews).

Strengths and limitations of each method will be discussed below. Combining these three methodological approaches (analysis of government data, online survey data and in-depth interviews) will provide insight into different aspects of changes in transport behaviour and help strengthen our overall understanding of those changes.

\subsection{Government data on use of transport in Barcelona}

Barcelona's transport authority (ATM) publishes the results of annual surveys of mobility behaviour on weekdays (Enquesta de Mobilitat en Dia Feiner (EMEF)). The surveys are representative for the users of „Barcelona's Integrated Metropolitan Mobility System”. The surveys provide a good overview of mobility behaviour capturing aspects such as citizens' main mode of transport, number of journeys, average duration of journey, mode of transport used by different age groups and occupational status (Autoritat del Transport Metropolità, 2019). Data for the year 2020 is not yet publicly available, data on citizen's preferences is also limited, and EMEF data does not capture mobility behaviour on weekends.

The City Council of Barcelona obtains daily data on road traffic intensity (motorcycles, cars and bicycles) through several detection stations across the city, which measure the intensity of traffic on bike lanes and traffic lanes. To distinguish between motorcycles and cars the stations read the license plates, and vehicles can be classified based on the vehicle registration at the city's General Directorate of Traffic (R. Rios, personal communication, January $18^{\text {th }}, 2021$ ). The City Council has published data on traffic intensity since the start of the pandemic compared to pre-pandemic levels (Ajuntament de Barcelona, 2020i). This data indicates development of mobility during the pandemic and can help estimate changes in GHG emissions from road traffic.

Data on the demand for public transport is published by ATM which monitors the number of ticket validations since the pandemic (Autoritat del Transport Metropolità de Barcelona, 2021).

Data on air pollution is provided by the City Council of Barcelona. The City measures hourly concentrations of different pollutants at several stations across the City and publishes the data on its open data portal (Ajuntament de Barcelona, 2020c). 
Behavioural changes in urban mobility in Barcelona due to the COVID-19 pandemic and its impact on air pollution and greenhouse gas emissions

\subsection{Online survey}

The online survey consisted of 100 participants commuting in Barcelona. It was designed and distributed using the online platform SurveyMonkey. It consisted of 19 questions including multiple choice questions, matrix questions, Likert scale and demographic questions (for details, see questionnaire in the Appendix, Questionnaire online survey).

Participants were recruited in December 2020 and January 2021 using Amazon Mechanical Turk (MTurk). The survey targeted people located in Spain who circulate regularly in Barcelona since at least January 2020. In terms of the representativeness of MTurk participants, results from surveys indicate that they 'generally provide high-quality data and are reasonably representative of the general population' - though females can be underrepresented (Levay et al., 2016; Morey \& McCredie, 2019). For this study's sample, females were indeed underrepresented and participants were overall younger and more educated than Barcelona's overall population, which is common in online surveys (Szolnoki \& Hoffmann, 2013) (Table 1 below provides full demographics of the sample). Participants received a payment of $\$ 1$ for completing the survey, which is comparable with payments for completing academic surveys of similar length via MTurk (Levay et al., 2016; Walters et al., 2018).

Table 1: Demographics of survey sample.

\begin{tabular}{|c|c|c|}
\hline Category & Value & $\begin{array}{c}\text { Share of sample } \\
\text { (out of } 100 \% \text { for each } \\
\text { category) }\end{array}$ \\
\hline \multirow[t]{3}{*}{ Gender } & male & 70 \\
\hline & female & 29 \\
\hline & other & 1 \\
\hline \multirow[t]{4}{*}{ Age } & $18-25$ years & 22 \\
\hline & $26-35$ years & 48 \\
\hline & $36-45$ years & 22 \\
\hline & $>45$ years & 8 \\
\hline \multirow[t]{4}{*}{ Occupation } & Student & 20 \\
\hline & Employee & 59 \\
\hline & Independent & 13 \\
\hline & Unemployed & 7 \\
\hline \multirow[t]{3}{*}{ Education } & Primary & 0 \\
\hline & Secondary & 12 \\
\hline & Tertiary & 88 \\
\hline \multirow[t]{4}{*}{ Income (net per month in EUR) } & $<800$ & 13 \\
\hline & $800-1500$ & 38 \\
\hline & $>1500$ & 35 \\
\hline & No response & 14 \\
\hline \multirow[t]{11}{*}{ District } & Outside of Barcelona & 14 \\
\hline & Ciutat Vella & 8 \\
\hline & Eixample & 15 \\
\hline & Sants - Montjuic & 9 \\
\hline & Les Corts & 6 \\
\hline & Sarrià- Sant Gervasi & 3 \\
\hline & Gràcia & 13 \\
\hline & Horta-Guinardó & 2 \\
\hline & Nou Barris & 4 \\
\hline & Sant Andreu & 5 \\
\hline & Sant Martí & 9 \\
\hline
\end{tabular}


Behavioural changes in urban mobility in Barcelona due to the COVID-19 pandemic and its impact on air pollution and greenhouse gas emissions

Corinna Peters

Conducting an anonymous online survey has the advantage of reaching a large number of individuals in a short amount of time at low cost (Evans \& Mathur, 2005). Also, it reduces the social desirability bias that involves the tendency of respondents to answer questions in a manner that will be viewed positively by interviewers or others. This bias is usually lower on anonymous surveys as compared to face-to-face research (Nayak \& Narayan, 2019).

However, online surveys also have disadvantages. Firstly, such surveys exclude people who are not online. They are not nationally representative in terms of the distribution of age, gender and education (Szolnoki \& Hoffmann, 2013). Secondly, online surveys do not allow for clarifying possible uncertainty with a question that an interviewee may have (Evans \& Mathur, 2005). For the present study, the questionnaire was tested in several pilots with multiple respondents to ensure the questions were clear and easy to understand.

\subsection{In-depth interviews}

In-depth interviews are a commonly used method in qualitative research. They can provide rich information and allow for follow-up questions, probe additional information, justify previous answers, and connect multiple topics. They can help understand complex issues and provide a setting to uncover new insights that an interviewer may not have foreseen. The main disadvantages of this research method are that it is time consuming and information retrieved is not generalizable (Almeida et al., 2017).

For this study, two semi-structured in-depth interviews were conducted, one with a representative of the City Council of Barcelona (Adrià Gomila, Director of Mobility), and one with two representatives of Barcelona's transport authority (Lluis Alegre, Director of Mobility, and Xavier Sanyer, Head of Mobility Service). The guiding questions and a summary of the interviews can be found in the Appendix, Interview questionnaire for public administration officials of Barcelona and Summary of interviews.

\section{Context: The City of Barcelona}

This section provides an introduction to the City of Barcelona, focussing on factors that influence mobility patterns, namely the City's demography, geography, economy and climate. An analysis of Barcelona's mobility infrastructure and behaviour, as well as air pollution and GHG emissions will be presented in section 7.

Barcelona is the capital of the Autonomous Community Catalonia on the northeast coast of Spain. With a population of 1.7 million people in the city and 3.6 million in the Metropolitan Area it is one of the largest cities in Europe (Ajuntament de Barcelona, 2019). The City's population has been rising by more than $9 \%$ over the last 20 years (Ajuntament de Barcelona, 2020a). It is one of the most densely populated cities in Europe with more than 16.000 people per square kilometre in 2019 (ibid).

The City covers $101 \mathrm{~km}^{2}$ (Ajuntament de Barcelona, 2020a) and the Metropolitan Area 634 km² (Àrea Metropolitana de Barcelona, 2020b). Barcelona has a mountain range on one side and the sea on the other, which limits the City's possibilities to expand (or makes expansions more expensive). See map below for location and area of Barcelona. 
Behavioural changes in urban mobility in Barcelona due to the COVID-19 pandemic and its impact on air pollution and greenhouse gas emissions

\section{Map 1: Map of Metropolitan Area of Barcelona.}

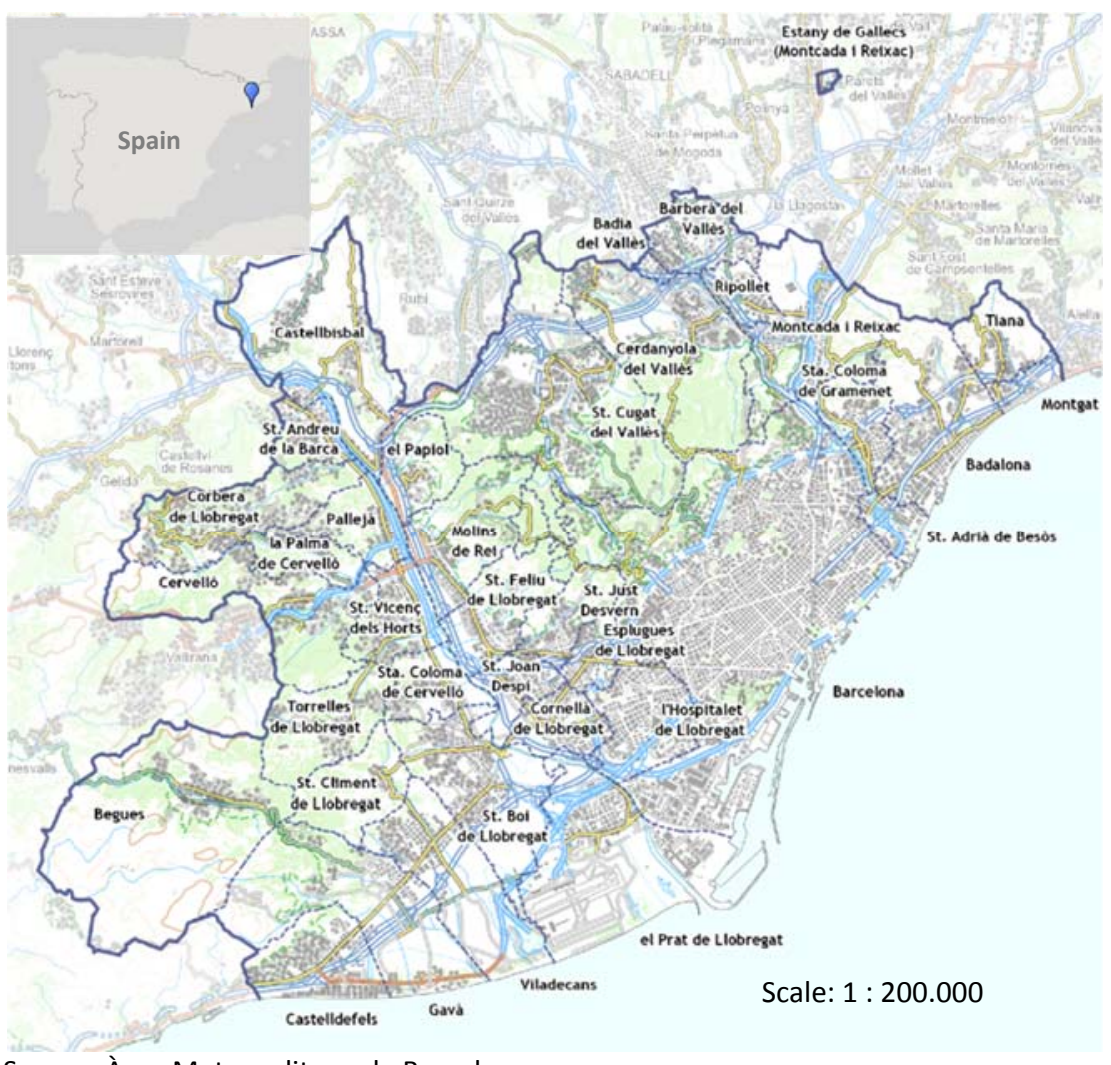

Source: Àrea Metropolitana de Barcelona.

Barcelona's economy is dominated by the service sector ( $90 \%$ of gross domestic product (GDP)). The largest subsector is 'commerce, transport and hospitality' contributing $25 \%$ to Barcelona's GDP, followed by the 'public administration, education, health and social services' subsector accounting for 19\% of the City's GDP (Ajuntament de Barcelona, 2020f). Tourism alone contributes $14 \%$ of the City's GDP and employs more than 150,000 people (Ajuntament de Barcelona, n.d.). Apart from its economic importance tourism also has a major impact on mobility with annually approximately 8.5 million tourists circulating in the City (ibid).

Table 2 below presents select demographic and socio-economic indicators for Barcelona and comparing it to Madrid. Barcelona and Madrid are the two largest cities of Spain. Providing data for Madrid can therefore help put the data on Barcelona in perspective. Most notable is the difference in population density, which underlines the high density in Barcelona. Also, the share of students is significantly higher in Barcelona, which might affect mobility behaviour. 
Universidad de Barcelona

Behavioural changes in urban mobility in Barcelona due to the COVID-19 pandemic and its impact on air pollution and greenhouse gas emissions

Corinna Peters

Table 2: Select demographic and socio-economic indicators, Barcelona and Madrid, 2019.

\begin{tabular}{|l|l|l|}
\hline Indicator & Barcelona & Madrid \\
\hline Population (in millions) & 1.7 & 3.3 \\
\hline Population density (pers./(km²) & 16,442 & 5,517 \\
\hline Women (\% of total population) & 52.6 & 53.5 \\
\hline Median age in years & 43.7 & 43.9 \\
\hline Citizens employed (\% of total population) & 44.6 & 44.6 \\
\hline $\begin{array}{l}\text { Unemployment rate (\% of economically active } \\
\text { population) }\end{array}$ & 9 & 11 \\
\hline Students (\% of total population) & 13 & 7 \\
\hline Average disposable annual income in EUR (2017) & 23,028 & 23,681 \\
\hline Number of tourists (in millions) & 8.5 & 10.4 \\
\hline
\end{tabular}

Source: (Ajuntament de Barcelona, 2020a); (Ayuntamiento de Madrid, 2020); (European Comission, 2020); (Madrid Destino, 2020); (Ajuntament de Barcelona, 2020j).

Note: Tourists are defined as visitors spending at least one night in the city.

Barcelona has a Mediterranean climate with hot and dry summers $\left(23^{\circ} \mathrm{C}\right.$ to $24^{\circ} \mathrm{C}$ on average) and mild winters $\left(9^{\circ} \mathrm{C}\right.$ to $11^{\circ} \mathrm{C}$ on average) (Agencia Estatal de Meteorología, 2020). Autumn is the main rainy season (Generalitat de Cataluna, 2014). The average annual rainfall is approximately $590 \mathrm{~mm}$ which falls on around 53 days throughout the year (Agencia Estatal de Meteorología (AEMET), 2020). Average annual hours of sunshine are approximately 2500 (UN data, 2010).

There is a clear upward trend of temperatures in Barcelona over the last 220 years (see Figure 1 below). Especially since 1970 temperatures are rising sharply, which Catalonia's Meteorological Service attributes to global warming (Servei Meteorològic de Catalunya, 2021b). With an annual mean temperature of $16,8 \mathrm{C}^{\circ}$ the year 2020 has been Barcelona's hottest year since 1780 (earliest year for which data is available) (see Figure 1 below). 2020 was also comparatively sunny with almost 2800 hours of sunshine (Servei Meteorològic de Catalunya, 2021a). Annual precipitation has also experienced an increase, although less striking. In the year 2020 annual rainfall was $724 \mathrm{~mm}$, thus being significantly above the average (see Figure 2 below).

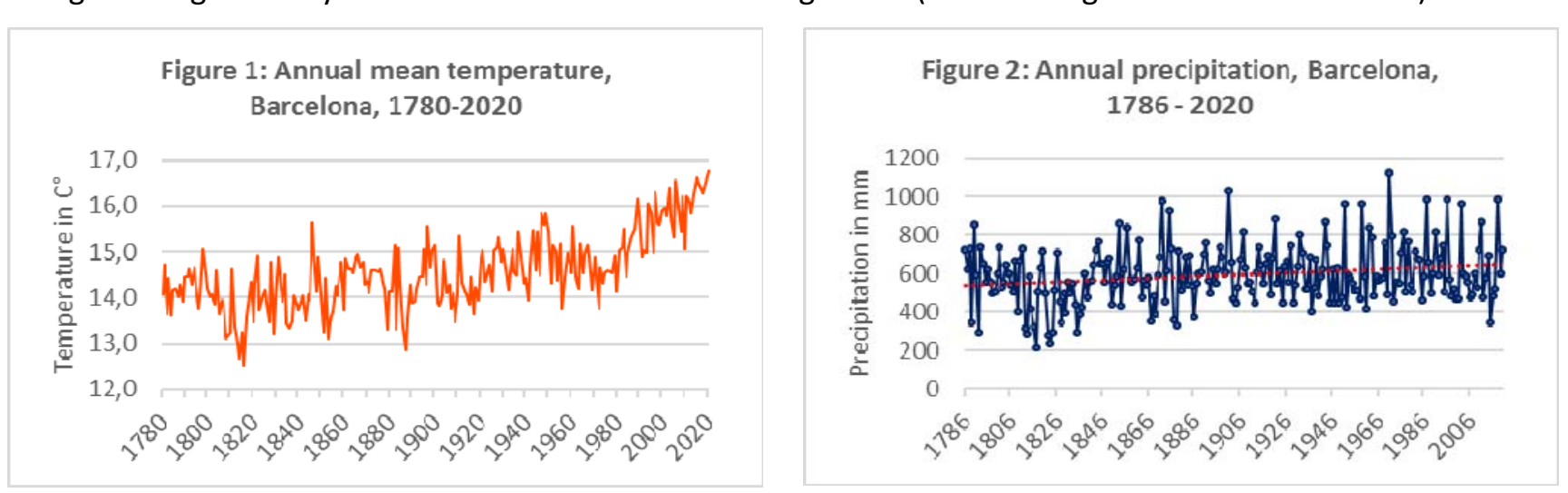

Source: Own illustrations based on data from Catalonia's Meteorological Service (Servei Meteorològic de Catalunya, 2021b).

Overall, Barcelona provides good conditions for walking and cycling with its Mediterranean climate, relatively small area, high population density and mostly flat topography. In addition, its high 
Universidad de Barcelona

Behavioural changes in urban mobility in Barcelona due to the COVID-19 pandemic and its impact on air pollution and greenhouse gas emissions

Corinna Peters

population density also has favourable conditions for an effective public transport system (Santos et al., 2013).

\section{COVID-19 pandemic in Barcelona}

This section outlines the development of the COVID-19 pandemic in Barcelona from February 2020 to December 2020. It provides an overview of daily confirmed cases ${ }^{1}$ and political measures implemented to limit the spread of the virus, as well as a brief summary of the pandemic's impact on the City's economy.

Nationwide lockdown measures came into force in Spain on March 14th, 2020, around two weeks after the start of the COVID-19 outbreak in the country. As one of the countries hardest hit by the virus, the mobility restrictions during the lockdown in Spain were among the strictest globally. Barcelona's citizens were only allowed to leave their homes to fulfil vital needs like grocery shopping, doctor's appointments or commuting to work. Two weeks into the lockdown, only workers in professions deemed essential to maintain the basic functions of society, such as the provision of food, water, energy, health care, and internet among others, were allowed to commute (Baldasano, 2020; Gobierno de España, 2020).

After one month of strict confinement and a substantial reduction in infections ${ }^{2}$, hospitalizations and registered deaths ${ }^{3}$ in Barcelona, restrictions were eased gradually (Ajuntament de Barcelona, 2021f). On April 13th professionals from sectors deemed "non-essential" were granted permission to return to work with a few exceptions such as people working in bars and leisure facilities, which had to remain closed (DMQ - eldesmarque, 2020; La Vanguardia, 2020a). With this date, mobility slowly started to increase (as outlined in section 8.1 below). From April 26, children under 14 have been allowed out for an hour a day, with an adult and not further than $1 \mathrm{~km}$ away from home any time from 9am to 9pm (ACN, 2020a).

On April 28th the Spanish Government announced a four-phased de-escalation plan to lift lockdown restrictions. Different regions should transition to different phases at a different pace according to specific epidemiological criteria and capacity in intensive care unit facilities, ability to carry out PCR tests on all suspected cases, as well as being able to isolate them and test all their contacts (Ministerio de Sanidad de España, 2020a; Spain in English, 2020).

On May $2^{\text {nd }}$ phase 0 of the de-escalation started in all parts of Spain with people being allowed to exercise or walk outside individually for certain time slots during the day within their municipality (La

\footnotetext{
${ }^{1}$ Please note that daily confirmed cases can be misleading when using it as a single indicator to evaluate the severity of the pandemic. When the first wave of infections hit the country in February/March 2020, probably, a large share of cases was not detected due to limited testing, while at a later stage testing increased and therefore more cases could be detected. Catalonia ramped up its testing capacities and number of tests conducted from around 5,000 daily PCR test in March to 30,000 in October (Henríquez et al., 2020; Mouzo, 2020). Nevertheless, confirmed cases can be an early warning sign for the need to implement political measures to restrain the spread of the virus.

2 Daily confirmed cases in Barcelona reduced from more than 600 on March 26th to less than 200 in mid-April (Ajuntament de Barcelona, 2021f)

${ }^{3}$ The number of daily registered deaths experienced a spike in March 2020 (from 59 in March 16th to 186 on March $31^{\text {st }}$ ) which reduced to 87 on April $15^{\text {th }}$. This spike was very high compared to number of deaths throughout the rest of 2020 with daily deaths ranging between 30 to 50 (Ajuntament de Barcelona, 2021f).
} 
Universidad de Barcelona

Behavioural changes in urban mobility in Barcelona due to the COVID-19 pandemic and its impact on air pollution and greenhouse gas emissions

Corinna Peters

Vanguardia, 2020c). On that Saturday Barcelona's citizens rushed to the city's seaside and parks to exercise outdoors (El Periodico, 2020; La Vanguardia, 2020b). Apart from this measure, this phase allowed small businesses $\left(<400 \mathrm{~m}^{2}\right)$ to reopen by appointment (such as restaurants for takeaway services only) and basic training for professional sports (ACN, 2020b; Ministerio de Sanidad de España, 2020b). Wearing face masks on public transport became mandatory (ACN, 2020c; Ministerio de Sanidad de España, 2020b).

Mid-May, when many regions moved to phase 1 , Barcelona did not yet meet the necessary criteria (Benito \& Cuè, 2020). However, the Spanish Government allowed the City to introduce a phase 0,5 granting certain flexibilities as compared to phase 0 . For example, small stores could open without the need for appointments, and larger stores could open a smaller area of their premises, up to $400 \mathrm{~m}^{2}$. Officially, libraries could open for lending, and museums to one third of capacity, but in both cases the majority chose not to. Mass was celebrated at Barcelona Cathedral for the first time in months with places of worship now permitted to open to one third capacity. Bars and restaurants remained closed however, only able to offer takeaway services (ACN, 2020e; Benito \& Cuè, 2020). Mobility remained limited to the municipality, except for work reasons (La Vanguardia, 2020c).

The City of Barcelona finally moved to phase 1 on May 25 $5^{\text {th }}$ (El Pais, 2020; Esteban \& Romero, 2020; Romero \& Escudero, 2020). Phase 1 allowed, among others, social gatherings of up to 10 people, the reopening of restaurant terraces at up to $50 \%$ capacity, the reopening of hotels and other tourist accommodations as long as they kept common areas closed, non-professional sports for activities that do not involve physical contact or the use of locker rooms (like tennis or athletics), cultural events outdoors up to 200 people and indoors up to 30 people at up to one third capacity, travelling within the health zone (for Barcelona that was only the Metropolitan Area itself), and reopening of schools and universities for administrative tasks and implementing hygiene measures (ACN, 2020d; El Pais, 2020; Ministerio de Sanidad de España, 2020c).

Two weeks later, on $8^{\text {th }}$ June, Barcelona passed to phase 2, in which restaurants and bars were allowed to open their indoor seating area at a third of their capacity. Cinemas, theatres and exhibitions were also permitted to open at a third of their capacity, as well as shopping malls and recreational swimming pools with similar limitations. Accessing the beaches was permitted. Cultural events were allowed with a maximum of 400 people outdoors and 50 indoors. Schools could not open fully, but were authorized to open for certain activities, e.g. to take of children under 6 years of age whose parents both work (López, 2020; Ministerio de Sanidad, 2020). Mobility remained restricted to the health zone (Vilaseró, 2020a). Time slots for walks and exercise were also lifted, except for the time slots reserved for elderly people (ACN, 2020b; Ministerio de Sanidad, 2020).

On the $18^{\text {th }}$ of June, just three days before the end of the state of emergency, Barcelona moved to the finale stage of the lockdown de-escalation. People were now allowed to move freely within Catalonia. Most activities were permitted, always maintaining the appropriate security and distance measures. Bars and nightclubs could open at limited capacities, as well as retail trade that had not previously opened (Ministerio de Sanidad de España, 2020d; Vilaseró, 2020b).

On June $21^{\text {st }}$ the state of emergency ended, and all regions of Spain transitioned to the so-called "New Normality". All social and economic restrictions were lifted, but epidemiological surveillance, high capacities of the health care system and self-protection measures, such as wearing a face mask in public places, remained in place (Ministerio de Sanidad de España, 2020d). Also, visitors from 
Universidad de Barcelona

Behavioural changes in urban mobility in Barcelona due to the COVID-19 pandemic and its impact on air pollution and greenhouse gas emissions

Corinna Peters

other Schengen countries were allowed to enter Spain without having to undergo a two-week quarantine period (EURACTIV, 2020).

With the end of restrictions, infections rose rapidly in Barcelona from below 50 daily confirmed cases per day in June to around 350 in mid-July (Ajuntament de Barcelona, 2021f). Over the summer the Government of Catalonia (re)introduced certain restrictions, such as obliging people to wear face masks in public spaces, prohibiting the consumption of alcoholic beverages in public spaces, and limited social gatherings to 10 later 6 people.

Schools in Catalonia reopened on September $14^{\text {th }}$ returning to presential classes (Catà Figuls, 2020). Two weeks later infections surged again - after having remained at a fairly constant level since July and reached its so far highest level measured in Barcelona with 1,411 daily confirmed cases on October $21^{\text {st }}$ (Ajuntament de Barcelona, 2021f). Experts argued that there were several potential causes for the sudden increase in infections, likely the (i) reopening of schools, (ii) the change in lifestyle from summer to autumn, i.e. spending more time in closed areas, and (iii) Barcelona's interconnectivity to high-infection places like Madrid and Paris (Güell, 2020).

To contain this new wave of the virus, Catalonia re-implemented stricter social and economic restrictions (Generalitat de Cataluña, 2020c). As of October $15^{\text {th }}$, bars and restaurants had to close again, while still being allowed to offer takeout services. Businesses with close contact to customers had to suspend their activities. Places of worship, sports centres, and cultural venues (like cinemas and theatres) could only open at $50 \%$ capacities. Classes for children could still be done face-to-face, whereas presential university classes were suspended (Generalitat de Cataluña, 2020c).

On October 25th, a curfew was imposed, restaurants and bars had to remain closed, sports and social activities were reduced and travelling between municipalities was only allowed on weekends (Cercós, 2020). On November $23^{\text {rd }}$ some restrictions were lifted, but the curfew and mobility limitations remained in place (Ajuntament de Barcelona, 2020g).

On December $21^{\text {st }}$ more stringent restrictions were imposed, with a few exceptions for the holidays (Generalitat de Cataluña, 2020b). Social gatherings were only allowed up to 6 persons, but for Christmas and New year's this was extended to up to 10 people. Travelling in Catalonia was allowed from December 23rd to January 6th to visit family members. The curfew was adapted slightly (starting at $1 \mathrm{am}$ instead of $10 \mathrm{pm}$ on Christmas and New Year's). Restaurants could only open in the morning and for lunch hours, but could offer takeout services until $10 \mathrm{pm}$ and delivery until $11 \mathrm{pm}$ (Generalitat de Cataluña, 2020b).

Figure 3 below outlines the development of the COVID-19 pandemic in Barcelona in the year 2020, portraying daily confirmed cases and selected measures to contain the spread of the virus.

Overall, the pandemic and the respective restrictions have had (and still have) a major impact on Barcelona's citizens. Apart from limited freedom of movement and social interactions the pandemic has had severe repercussions on the City's economy (Ajuntament de Barcelona, 2021c). The destruction of employment has been more intense in Barcelona than in the rest of Catalonia and Spain. Barcelona's unemployment rate has surged from 8,5 \% in 2019 to $12,6 \%$ in 2020 (approximately 94,000 people unemployed in December) (ibid; Ajuntament de Barcelona, 2020g). Sectors such as administrative activities and auxiliary services have lost up to $8 \%$ of jobs in 2020 and in the hospitality industry the loss of jobs has been more than $18 \%$ (ibid). The number of tourists has 
Universidad de Barcelona

Behavioural changes in urban mobility in Barcelona due to the COVID-19 pandemic and its impact on air pollution and greenhouse gas emissions

Corinna Peters

dropped to 1.9 million in 2020 which represents a decrease by almost $80 \%$ compared to 2019 (Ajuntament de Barcelona, 2020h; 2021c).

The impact on mobility, air quality and GHG emissions will be analysed in the section 8 . 
Figure 3: Timeline of COVID-19 pandemic in Barcelona

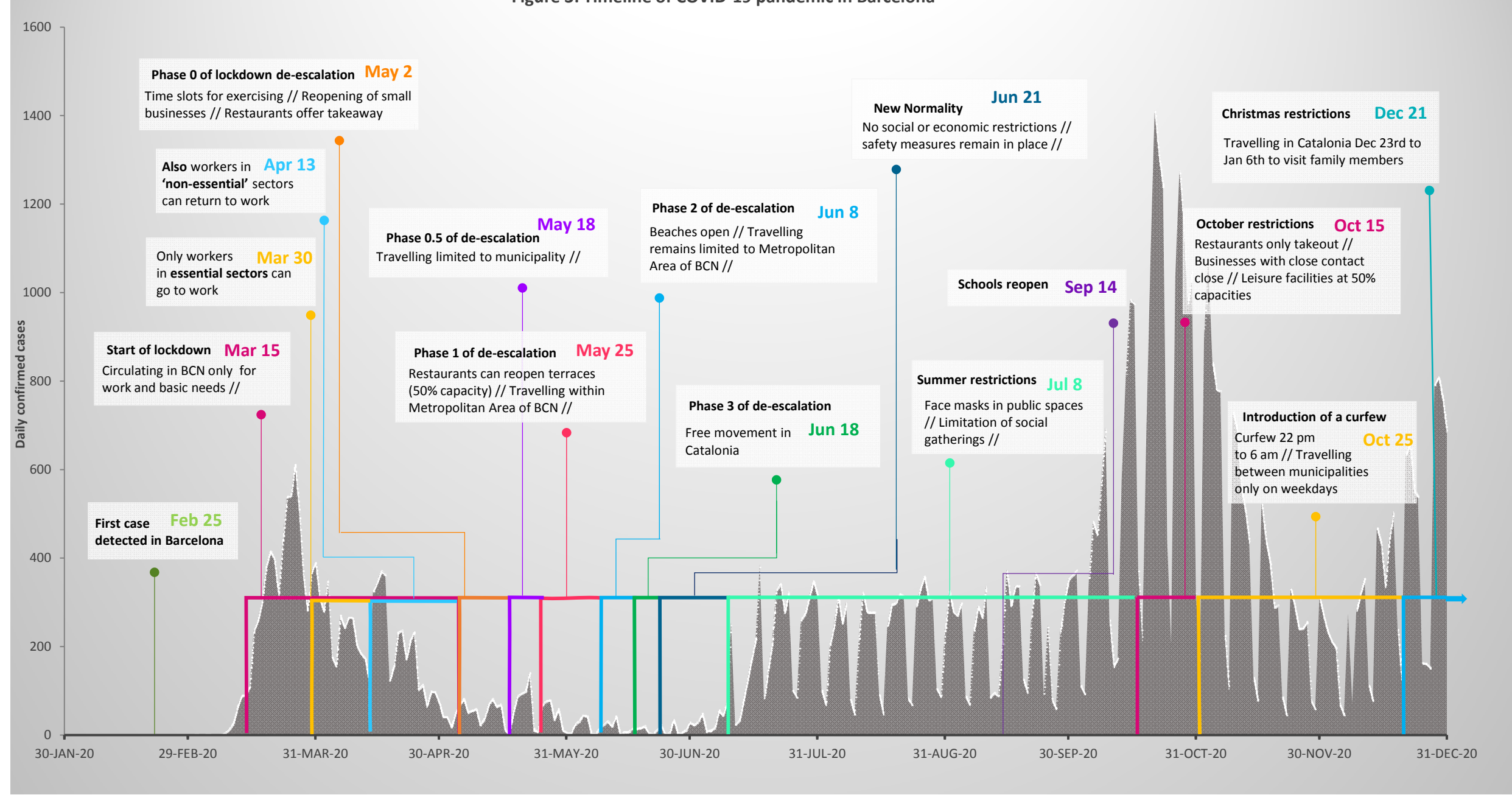

Source: Own illustration based on data from the City Council of Barcelona, newspaper articles and official government communications as indicated in this section above. 
Universidad de Barcelona

Behavioural changes in urban mobility in Barcelona due to the COVID-19 pandemic and its impact on air pollution and greenhouse gas emissions

Corinna Peters

\section{Pre-pandemic mobility, air quality and GHG emissions}

\subsection{Mobility}

This section provides an overview of Barcelona's mobility infrastructure, pre-pandemic mobility patterns and current main mobility policies. This is to understand current trends and later how the pandemic has affected these trends.

\section{Mobility infrastructure}

Barcelona offers different mobility options to commuters. With its high population density Barcelona has good conditions for an effective public transport network (Santos et al., 2013). It provides public transport services through an extensive network of metro and bus lines, complemented with tramlines and urban railway services (Ferrocarril de Generalitat de Catalunya (FGC), and Rodalies) (Pérez Díez et al., 2018). In the last five years ${ }^{4}$ the railway network (including metro, tramlines, FGC and Rodalies) was extended slightly to $304 \mathrm{~km}$, whereas the bus network was marginally reduced to $835 \mathrm{~km}$ (see Figure 4 below) (Ajuntament de Barcelona, 2020a). Railway services in terms of train arrivals per hour (during rush hour) have increased by 9\% in the last five years to 248 in 2019 (ibid).

Barcelona's cycle network has almost doubled in the last five years reaching around $230 \mathrm{~km}$ in 2020 (Ajuntament de Barcelona, 2020a; Urra et al., 2020). That translates into a network of around $14 \mathrm{~km}$ per 100.000 inhabitants. In a recent study by the newspaper "EL PAÍS" analysing the cycle network of 13 Spanish cities, Barcelona ranked 9th behind cities like Sevilla $(28 \mathrm{~km} / 100.000$ inh.) and Valencia (20 km/100.000 inh.), but before Bilbao (10 km/100.000 inh.) and Madrid (8 km/100.000 inh.) (Urra et al., 2020). Compared to well-known cycling-friendly cities like Copenhagen with a cycle network of $65 \mathrm{~km}$ per 100.000 inhabitants Barcelona lags far behind (City of Copenhagen, 2018; StatBank Denmark, 2020b). The same holds true when comparing the length of the cycling network per area, though the difference is less striking. The City of Copenhagen is slightly smaller than Barcelona covering $90 \mathrm{~km}^{2}$ (StatBank Denmark, 2020a). Its cycling network is almost twice as long as Barcelona's with $415 \mathrm{~km}$ (City of Copenhagen, 2018). Thus, Copenhagen provides $4.7 \mathrm{~km}$ cycling network per $\mathrm{km}^{2}$, whereas Barcelona provides $2.3 \mathrm{~km}$ per km².

The bike sharing service „Bicing" offers 6,300 bicycles at 422 stations across the City. The service has gained popularity in the last years with around 112,000 subscribers as of 2019 as compared to 95,000 in 2015 (Ajuntament de Barcelona, 2020a).

The road network extends to around 1,377 km throughout the city covering around 1,130 ha (Ajuntament de Barcelona, 2020a). As can be seen in Figure 4 the space dedicated to the circulation of motorized vehicles has remained almost constant since 2014.

Pedestrian priority areas have increased by around $30 \%$ in the last five years reaching approximately 130 ha in 2019 (see Figure 4 below) (Ajuntament de Barcelona, 2020a). According to data from the

\footnotetext{
${ }^{4}$ Data for earlier years was limited, therefor the last five years were selected for this analysis.
} 
Universidad de Barcelona

Behavioural changes in urban mobility in Barcelona due to the COVID-19 pandemic and its impact on air pollution and greenhouse gas emissions

Corinna Peters

Institute for Transportation \& Development Policy Barcelona ranks among the top 150 most walkable cities out of 347 cities across the globe (Institute for Transportation \& Development Policy, 2020).

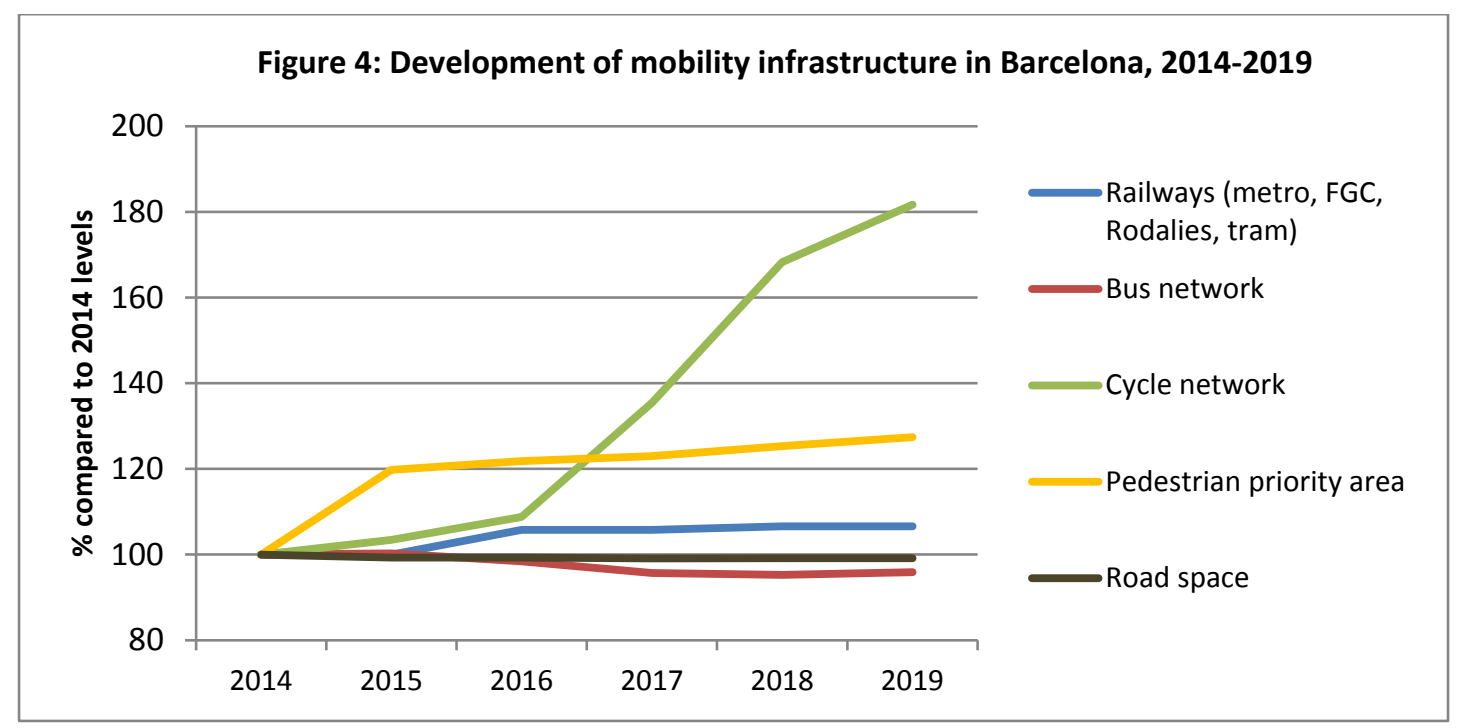

Source: Own illustration based on annual statistics reports from the City Council of Barcelona (Ajuntament de Barcelona, 2020a).

\section{Mobility Behaviour}

Barcelona's citizens mostly use some form of active mobility to move from one point to another on weekdays (see Figure 5 below). According to the 2019 mobility survey by Barcelona's transport authority (Enquesta de Mobilitat en Dia Feiner (EMEF)) the most popular mode of transport among Barcelona's citizens on weekdays is walking, accounting for about $41 \%$ of trips originating or ending in Barcelona (Autoritat del Transport Metropolità, 2020). The State of Cities Report 2016 by the European Commission states that $30 \%$ of Barcelona citizens use walking as their preferred mode of transport. In comparison to other European citizens Barcelona takes a middle rank in this regard with Paris at the high end, where more than $50 \%$ of citizens use walking as their main mode of transport, and Valletta, the capital of Malta, at the low end with 13\% (European Comission, 2016). ${ }^{6}$

Despite good conditions for cycling with a Mediterranean climate, a relatively small area and little elevation in large parts of the city, cycling plays a minor role in mobility on weekdays in Barcelona

\footnotetext{
${ }^{5}$ The ranking is based on indicators such as "share of population living within $1 \mathrm{~km}$ to a car-free zone". The database includes 962 cities, but data for most cities was deemed unreliable by the Institute for Transportation \& Development Policy. For this study only the 347 cities with more reliable data were included. However, the database does not specify the year of the data and how the data was obtained, hence the reliability of the data could not be checked, and the ranking should merely provide an indication.

${ }^{6}$ Unfortunately, the State of Cities Report does not provide modal split data. EPOMM provides modal split data for European cities, but for most of the data is outdated. EUROStat offers data on modal share, but only for trips to work and the data is also outdated in parts.
} 
Behavioural changes in urban mobility in Barcelona due to the COVID-19 pandemic and its impact on air pollution and greenhouse gas emissions

(2\% of trips). Bike-friendly cities like Copenhagen have reached modal shares for cycling of more than $28 \%$ (City of Copenhagen, 2018)

Public transport is used for $33 \%$ of trips on weekdays in Barcelona, with the metro being used most often (see Figure 5 below). Compared to other European cities, public transport seems to be highly popular among Barcelona's citizens with $67 \%$ stating that public transport is their preferred mode of transport. Barcelona thereby reaches almost similar levels like Paris (69\%), Zürich (70\%) or Vienna (72\%), cities where public transport is particularly popular (European Comission, 2016).

Motorized private transport accounts for $23 \%$ of trips on weekdays in Barcelona (see Figure 5 below). This is a rather low share compared to other cities in Europe (e.g. 78\% in Palermo or $45 \%$ in Lyon) (EPOMM, 2020; Hebel \& Wolek, 2017) ${ }^{8}$. The number of registered passenger cars has reduced slightly in the last five years to around 490,000 in 2019, which corresponds to 295 cars for every 1,000 inhabitants. Compared to many other European cities Barcelona ranks among the 100 cities with the lowest car density (rank 90 out of 706 cities), whereas Madrid takes a rank in the middle (409th) (European Comission, 2020). On the contrary, Barcelona has been cited to be one of the cities with the highest density in motorized two-wheelers in Europe (Ajuntament de Barcelona, 2020b; Marquet \& Miralles-Guasch, 2016). The number of motorcycles and mopeds circulating in the city has remained quite constant over the last five years amounting to 265,000 in 2019. This corresponds to 160 for every 1,000 inhabitants (Ajuntament de Barcelona, 2020a).

Figure 5: Modal share of mobility, Barcelona, 2019

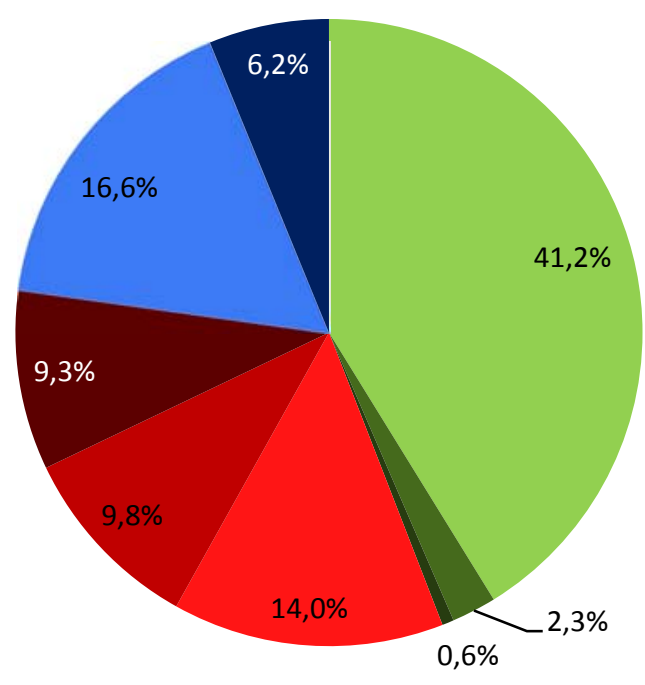

Walking

Bicycle

- Others (electric scooter, etc.)

- Metro

Bus

Other public transport (FGC, Rodalies, tramline, etc.)

Car or van

- Motorcycle

Source: Own illustration based on EMEF data (Autoritat del Transport Metropolità, 2020).

\footnotetext{
7 Please note that data for Copenhagen and the data for Barcelona is not directly comparable as it was retrieved from different data sources, and the data referring to Copenhagen includes all trips (weekdays and weekends), whereas data from Barcelona only refers to trips on weekdays.

${ }^{8}$ Please note that data for other European cities are not directly comparable to data from Barcelona, because they are from a different data source and were only available for the year 2015 or 2016.
} 
Behavioural changes in urban mobility in Barcelona due to the COVID-19 pandemic and its impact on air pollution and greenhouse gas emissions

Corinna Peters

When looking at the development of mobility behaviour over the last five years one can observe a tendency towards more active mobility. As shown in Figure 6 below, the number of trips taken by public transport and private vehicles has remained almost constant over the last 5 years, whereas the number of trips by bicycle or walking (active mobility) has increased significantly since 2017 from around 2 million to more than 3 million trips per weekday in 2019 rising to levels higher than in 2015.

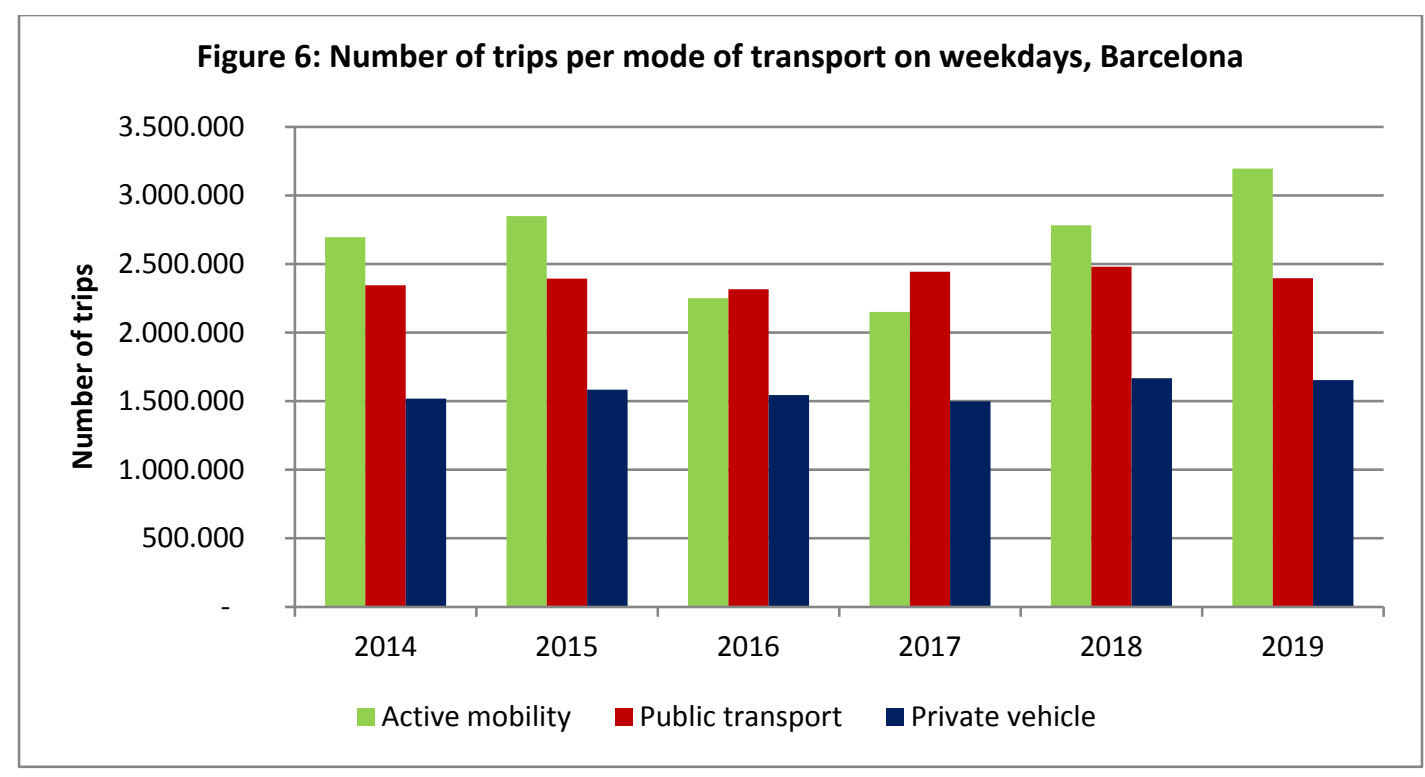

Source: Own illustration based on EMEF data (Autoritat del Transport Metropolità, 2019).

The EMEF data also shows the use of transport of Barcelona's citizens according to age. The share of trips taken by active mobility is highest among persons aged 65 or more $(66 \%$ of trips of this age group), as compared to other age groups (see Figure 7 below). The share of trips travelled by public transport is highest among the youngest age group (41\%), and using private vehicle is most common for the age group 30 to 64 years (23\%).

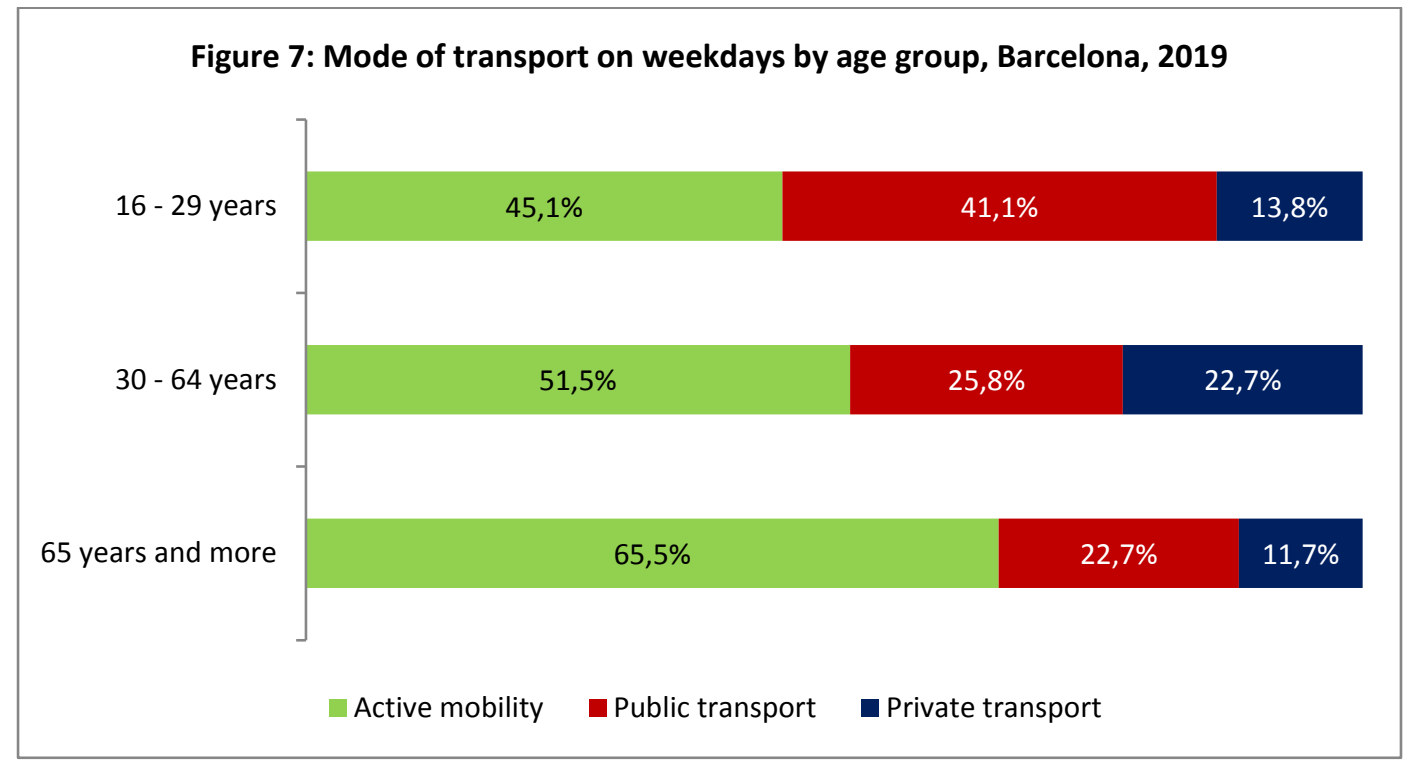

Source: Own illustration based on EMEF data (Autoritat del Transport Metropolità, 2020). 
Universidad de Barcelona

Behavioural changes in urban mobility in Barcelona due to the COVID-19 pandemic and its impact on air pollution and greenhouse gas emissions

Corinna Peters

\section{Policies}

As many other metropolitan areas, the mobility of Barcelona is confronted with common problems such as congestion and pollution. Barcelona's authorities have implemented actions aimed at lowering car use, decreasing accidents, relieving congestion and reducing emissions of greenhouse gases (Pérez Díez et al., 2018). The City has often been cited as a front-runner when it comes to sustainable urban development, including urban mobility policies, e. g. for its implementation of "superblocks" (car-free zones in the city centre) (Mueller et al., 2020).

Barcelona's guiding policy document for urban mobility the "Urban Mobility Plan 2024" aims to, among others, increase the percentage of trips travelled via low-emission modes of transport (e.g. increase the modal share of cycling to $5 \%$ and of public transport to $41 \%$ ), and decrease the share of trips travelled by individual motorized transport (to 18.5\%). Key measures foreseen are, among others, (i) defining more low emission zones, (ii) extending the network of pedestrian areas, bike lanes and bus lanes, (iii) increasing the frequency in train arrivals in certain areas, (iv) supporting companies and institutions in developing mobility plans, ( $v$ ) decreasing the speed limit to $30 \mathrm{kmh}$ in the City (except for connection roads), (vi) increasing the share of electric vehicle of the City's vehicle fleet to $80 \%$, and (vii) improving the regulation of delivery services. The overall costs of implementing the measures proposed are estimated to be approximately 7.2 million EUR!(Ajuntament de Barcelona, 2020e, 2020h; Autoritat del Transport Metropolità de Barcelona, 2020).

During the pandemic Barcelona has added more kilometres in bike lanes than any other Spanish city. The cycle network was extended by 21 temporary kilometres (which will become permanent). Eight further kilometres are planned. The bike lanes run through the city centre, taking space away from motor vehicles (Urra et al., 2020).

\subsection{Air quality}

This section outlines the key issues related to air pollution in Barcelona. It provides background information on two of the most relevant pollutants, their respective levels and sources as well as limit values set by the EU and recommended by the WHO.

The complex topography of the Metropolitan Area of Barcelona is characterized by inland mountain ranges, which block the dispersion of pollutants, while the valleys of the rivers Llobregat and Besòs play an important role in the creation of air-flow patterns. Thus, the atmospheric flow in Barcelona is complicated not only concerning urban heat island effects but also topographic flows and sea breezes which influence air pollution and human health (Rivas et al., 2014).

Barcelona annually reports one of the highest air pollution levels in Europe with some pollutants frequently reaching concentrations higher than the recommended values by the WHO guidelines and the respective EU Directive (Agència De Salut Pública Barcelona, 2020). Chronic exposure to such high levels is deemed to have severe effects on human health. The Public Health Agency of Barcelona estimates that air pollution levels beyond the recommended WHO guidelines are responsible for $7 \%$ of natural mortalities (about 1,000 annual deaths), 11\% of new lung cancer cases and $33 \%$ of new childhood asthma cases (Agència De Salut Pública Barcelona, 2020). 
Behavioural changes in urban mobility in Barcelona due to the COVID-19 pandemic and its impact on air pollution and greenhouse gas emissions

Corinna Peters

Barcelona measures the concentration of seven different pollutants (nitric oxide (NO), nitrogen dioxide (NO2), oxides of nitrogen (NOx), particulate matter with an aerodynamic diameter $<10 \mu \mathrm{m}$ (PM10), ozone (O3), carbon monoxide (CO), and sulfuric dioxide (SO2)) in real time at several stations across the City (Ajuntament de Barcelona, 2021e). This study will focus on PM10 and NO2 being two of the most problematic pollutants in Barcelona for which data is publicly available.

PM10

PM10, or respirable particulate matter, is the most frequently used indicator for suspended particles in the air. Particulate matter is a complex mixture with components having diverse chemical and physical characteristics. In urban atmospheres, PM can generally be separated into three major fractions according to particle size: coarse particles larger than $2.5 \mu \mathrm{m}$ in aerodynamic diameter (PM10), fine particles smaller than $2.5 \mu \mathrm{m}$ (PM2.5) and ultrafine particles, those smaller than $0.1 \mu \mathrm{m}$. By definition, PM10 includes PM2.5 and ultrafine particles, those inhalable particles that are sufficiently small to penetrate to the thoracic region and with a high probability of deposition in the smaller conducting airways and alveoli (World Health Organization, 2005).

PM10 are to a large extent mechanically produced by the break-up of larger solid particles. In urban areas, the coarse particles typically contain resuspended dust from roads and industrial activities, and biological material such as pollen grains and bacterial fragments. Coarse particles may also be produced by the release of non-combustible materials in combustion processes, i.e. fly ash (ibid). PM10 particles in Barcelona are formed by various emission sources, such as traffic, construction, soil resuspension, or dust from the Saharan desert (Agència De Salut Pública Barcelona, 2020). See Figure 8 below for overview of emission sources. Due to the high share of regionally transported particles, the peaks in the daily profile during rush hours is less pronounced compared to NO2 (Agència De Salut Pública Barcelona, 2020).

Figure 8: Emission sources PM10 in Barcelona
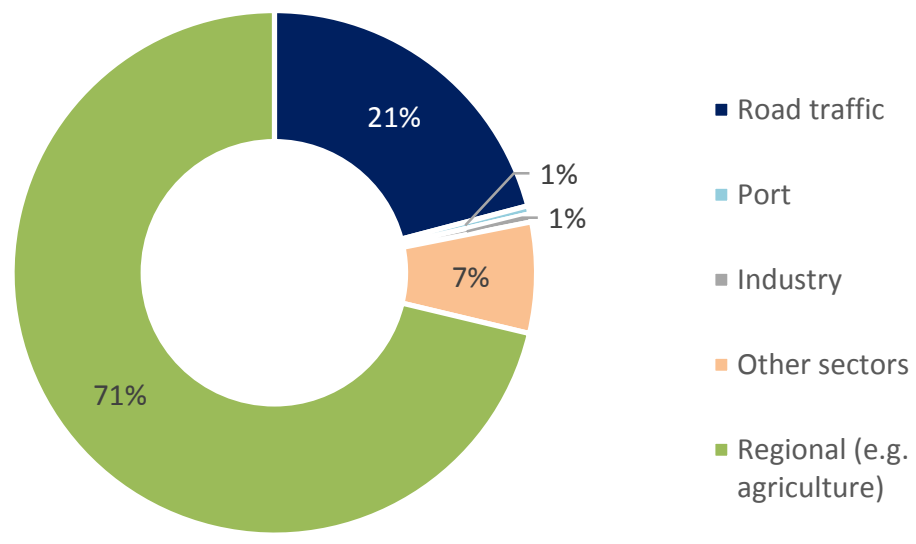

Source: Own illustration based on data provided by the City Council of Barcelona (Ajuntament de Barcelona, 2016).

Given the heterogeneity of its composition, research on PM and its risk to human health are complicated and the potential of particles to cause harm varies with size, chemical composition and 
Behavioural changes in urban mobility in Barcelona due to the COVID-19 pandemic and its impact on air pollution and greenhouse gas emissions

Corinna Peters

source. However, research has associated levels of PM with a number of health conditions, such as the exacerbation of symptoms in asthma, respiratory cancer, mortality and hospital admission in cardiovascular disease patients, as well as mortality and hospital admission in diabetes mellitus etc. (World Health Organization, 2005).

Based on this research, the WHO recommends that one day mean concentrations of PM10 should not exceed $50 \mu \mathrm{g} / \mathrm{m}^{3}$ and annual mean should not be higher than $20 \mu \mathrm{g} / \mathrm{m}^{3}$ (ibid). The EU Directive 2008/50/EC provides a legal framework for pollutant levels following WHO recommendations for the one day mean, specifying that this limit should not be exceeded more than 35 times a calendar year. With respect to the annual mean the EU Directive is less stringent setting the limit at $40 \mathrm{\mu g} / \mathrm{m}^{3}$ (Directive 2008/50/EC, 2008) (see Table 3 below).

According to the WHO, the annual average PM10 concentrations in Asian cities ranged from about 35 $\mu \mathrm{g} / \mathrm{m}^{3}$ to $220 \mu \mathrm{g} / \mathrm{m}^{3}$ and in Latin America from about $30 \mu \mathrm{g} / \mathrm{m}^{3}$ to $129 \mu \mathrm{g} / \mathrm{m}^{3}$, while in Europe and North America the typical range of annual average PM10 concentrations was $15-60 \mu \mathrm{g} / \mathrm{m}^{3}$ (World Health Organization, 2005).

Barcelona has shown annual mean PM 10 concentrations between $35 \mu \mathrm{g} / \mathrm{m}^{3}$ and $55 \mu \mathrm{g} / \mathrm{m}^{3}$ until 2010 thereby being at the higher end of European cities and frequently exceeding WHO and EU limits. Since 2010 annual averages in PM10 concentration are consistently below the $40 \mathrm{\mu g} / \mathrm{m}^{3} \mathrm{EU}$ limit, but still exceed the WHO recommendation of $20 \mu \mathrm{g} / \mathrm{m}^{3}$ (Agència De Salut Pública Barcelona, 2020). In 2019, annual mean level of PM 10 was $24 \mu \mathrm{g} / \mathrm{m}^{3}$ (Ajuntament de Barcelona, 2020c).

NO2

Nitrogen dioxide (NO2) is a reddish-brown gas with a characteristic pungent odour. Nitric oxide produces the dioxide when exposed to air. Nitrogen dioxide gas is a strong oxidant subject to extensive further atmospheric transformations that lead to the formation of other pollutants like sulfuric dioxide and sulfuric acid. The newly generated pollutants are an important source of organic, nitrate and sulphate particles currently measured as $\mathrm{PM}_{10}$ or $\mathrm{PM}_{2.5}$. For these reasons, $\mathrm{NO2}$ is a key precursor of a range of secondary pollutants (World Health Organization, 2005).

On a global scale, emissions of NO2 from natural sources far outweigh those generated by human activity. Natural sources include intrusion of stratospheric nitrogen oxides, bacterial and volcanic action, and lightning. However, as natural emissions are distributed over the entire surface of the earth, the resulting background atmospheric concentrations are very low. The major sources of anthropogenic emissions of NO2 are combustion processes (e.g. from power generation, vehicles and ships) (ibid). The Public Health Agency of Barcelona estimates that $60 \%$ de NO2 emissions in the city stems from road traffic (Agència De Salut Pública Barcelona, 2020). See Figure 9 below for an overview of emission sources. 
Behavioural changes in urban mobility in Barcelona due to the COVID-19 pandemic and its impact on air pollution and greenhouse gas emissions

Figure 9: Emission sources NO2 in Barcelona

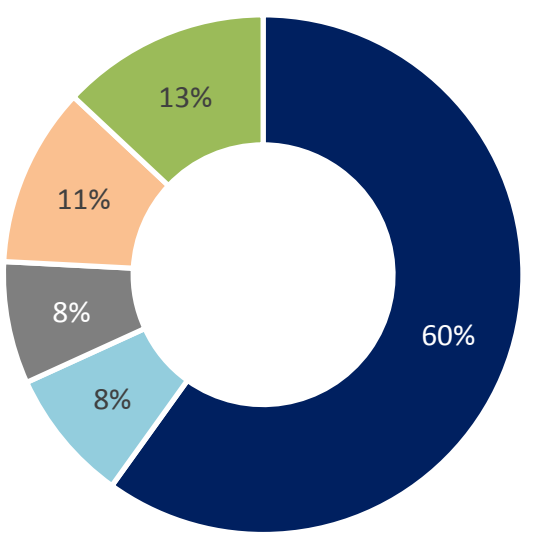

- Road traffic

- Port

- Industry

- Other sectors

- Regional

Source: Own illustration based on data provided by the City Council of Barcelona (Ajuntament de Barcelona, 2016).

Many studies are unable to separate the effects of nitrogen dioxide from those of other pollutants, especially fine particles. However, some epidemiological studies provide strong indications of an effect of $\mathrm{NO} 2$ on hospital admissions or emergency department visits for respiratory and cardiovascular diseases, and asthma aggravation. Research conducted in controlled environments suggests that for acute exposure concentrations of NO2 far beyond levels observed in urban areas (> $1880 \mathrm{\mu g} / \mathrm{m}^{3}$ ) are necessary to induce changes in pulmonary function in healthy adults (World Health Organization, 2005).

NO2 levels vary according to the time of day, the season of the year and meteorological factors. Typically, NO2 levels closely follow vehicle emissions. Daily patterns often include a low background level of nitrogen dioxide, with one or two peaks of higher levels that correspond to rush-hour traffic. $\mathrm{NO} 2$ is therefore a good indicator for traffic-induced air pollution as compared to particulate matter (ibid).

The WHO recommends that one hour peaks of $\mathrm{NO} 2$ concentrations should not exceed $200 \mu \mathrm{g} / \mathrm{m}^{3}$ and annual mean should not exceed $40 \mu \mathrm{g} / \mathrm{m}^{3}$ (ibid). The EU Directive requires these same limits for the for the annual mean as well as for the one hour peak, specifying that one hour limit should not be exceeded more than 18 times a calendar year (Directive 2008/50/EC, 2008) (see Table 3 below for EU and WHO limit values).

Annual mean nitrogen dioxide concentrations in urban areas throughout the world are generally in the range of $20-90 \mu \mathrm{g} / \mathrm{m}^{3}$ (World Health Organization, 2005). Over the last 20 years, Barcelona has seen high levels of NO2 reaching an annual mean concentration of $75 \mu \mathrm{g} / \mathrm{m}^{3}$ in 2005 at its measuring stations in high transit areas (Gràcia and Eixample). However, NO2 concentrations have dropped significantly to $45 \mu \mathrm{g} / \mathrm{m}^{3}$ in these areas in 2019. Levels of air pollution in low transit areas comply with WHO/EU limits since 2011 (Agència De Salut Pública Barcelona, 2020). Annual mean NO2 
Universidad de Barcelona

Behavioural changes in urban mobility in Barcelona due to the COVID-19 pandemic and its impact on air pollution and greenhouse gas emissions

Corinna Peters

concentration across all measuring stations was $33 \mu \mathrm{g} / \mathrm{m}^{3}$ in $2019^{9}$ (Ajuntament de Barcelona, 2020c).

The $200 \mu \mathrm{g} / \mathrm{m}^{3}$ one hour limit has been exceeded 5 times in 2019 thereby not complying with WHO guidelines, but remaining within EU limits (Agència De Salut Pública Barcelona, 2020).

Table 3: Air pollution limit values for the protection of human health

\begin{tabular}{|l|l|l|l|l|}
\cline { 2 - 5 } \multicolumn{1}{c|}{} & Pollutant & One hour & One day mean & Annual mean \\
\hline $\begin{array}{l}\text { EU Directive } \\
\text { 2008/50/EC }\end{array}$ & NO2 & $\begin{array}{l}200 \mu \mathrm{g} / \mathrm{m}^{3}, \text { not to be } \\
\text { exceeded more than } 18 \\
\text { times a calendar year }\end{array}$ & - & $40 \mu \mathrm{g} / \mathrm{m}^{3}$ \\
\cline { 2 - 5 } & PM10 & - & $\begin{array}{l}50 \mu \mathrm{g} / \mathrm{m}^{3}, \text { not to be } \\
\text { exceeded more than } 35 \\
\text { times a calendar year }\end{array}$ & $40 \mu \mathrm{g} / \mathrm{m}^{3}$ \\
\hline $\begin{array}{l}\text { WHO guideline } \\
\mathbf{2 0 0 5}\end{array}$ & NO2 & $200 \mu \mathrm{g} / \mathrm{m}^{3}$ & - & $40 \mu \mathrm{g} / \mathrm{m}^{3}$ \\
\cline { 2 - 5 } & PM10 & - & $50 \mu \mathrm{g} / \mathrm{m}^{3}$ & $20 \mu \mathrm{g} / \mathrm{m}^{3}$ \\
\hline
\end{tabular}

Source: (Directive 2008/50/EC, 2008; World Health Organization, 2005).

\subsection{Greenhouse gas emissions}

This section provides a brief introduction to the development of greenhouse gas emissions of the City of Barcelona over the last years. Data available concerning greenhouse gas emissions in Barcelona is far less detailed than data on air pollution. Barcelona's Energy Agency provides an annual energy balance, which includes data on GHG emissions.

From the year 2000 to 2018 GHG emissions in Barcelona have decreased by $27 \%$ to 3.6 million tons of $\mathrm{CO}_{2} \mathrm{eq}^{10}$. In 2005 emissions reached their maximum level exceeding 5 million $\mathrm{t}$ CO2eq but declined afterwards until 2014. Since then levels have increased slightly, although not reaching levels as high as in the early 2000s (see Figure 10 below). As there is a direct association between energy consumption and emissions of GHGs, one can conclude that the decline since 2008 is partly due to the economic crisis (Agència d'Energia de Barcelona, 2020). Yet, further research would be needed to support this claim and explain the reduction in emissions for the time before the economic crisis.

Emissions per capita have also declined substantially in the last years from above $3 \mathrm{t}$ CO2eq / inhabitant in 2000 to 2.2 in 2018 (Agència d'Energia de Barcelona, 2020).

\footnotetext{
${ }^{9}$ Data for 2020 will be analysed in section 8.

${ }^{10} \mathrm{CO}$ eq (carbon dioxide-equivalent): total emissions of all greenhouse gases converted to an equivalent amount of carbon dioxide. Barcelona's Energy Agency considers carbon dioxide ( $\mathrm{CO} 2)$, methane $(\mathrm{CH} 4)$ and nitrogen dioxide (N2O), as well as other fluorinated gases from industry (Agència d'Energia de Barcelona, 2020).
} 
Figure 10: Greenhouse gas emissions in Barcelona, 2000-2018.

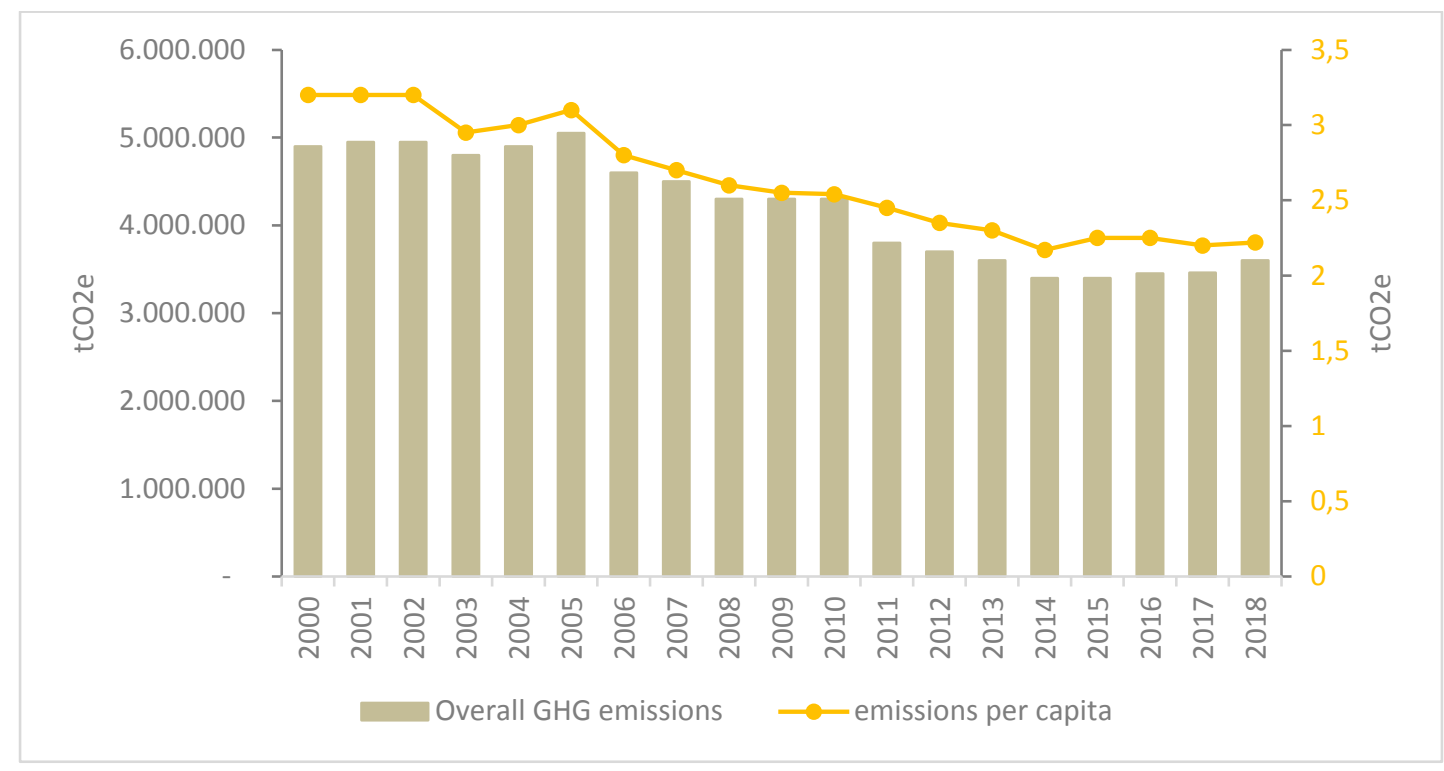

Source: Own illustration based on data from Barcelona's Energy Agency (Agència d'Energia de Barcelona, 2020).

The largest share of GHG emissions in 2018 were produced by the transport sector with $28 \%$ of the City's overall emissions (see Figure 11 below). According to the Energy Agency of Barcelona these emissions are mainly generated by private motorized transport. Over the years, emissions from private vehicles have remained fairly constant, reducing slightly from approximately 1.2 million $\mathrm{tCO}_{2} \mathrm{e}$ in 2000 to 1 million in 2018, but were estimated to decrease in the future due to the gradual renewal of vehicles and the implementation of low emission zones (Agència d'Energia de Barcelona, 2020). However, with the start of the pandemic it is difficult to project mobility choices in the future and therefore how emissions from road traffic will develop. The domestic sector, adding emissions from electricity and natural gas consumption, accounted for $21 \%$ of emissions, while commercial activities generated $20 \%$ of the city's GHG emissions. The port and the airport contributed a share of $13 \%$. Barcelona's Energy Agency projected that these emissions would likely increase in the coming years due to an uptake in tourism and new logistics centres (Agència d'Energia de Barcelona, 2020). Yet, as long as the pandemic requires mobility restrictions, tourism will likely remain on a low level. As for emissions from waste treatment, they account for $10 \%$ of total GHG emissions. 
Behavioural changes in urban mobility in Barcelona due to the COVID-19 pandemic and its impact on air pollution and greenhouse gas emissions

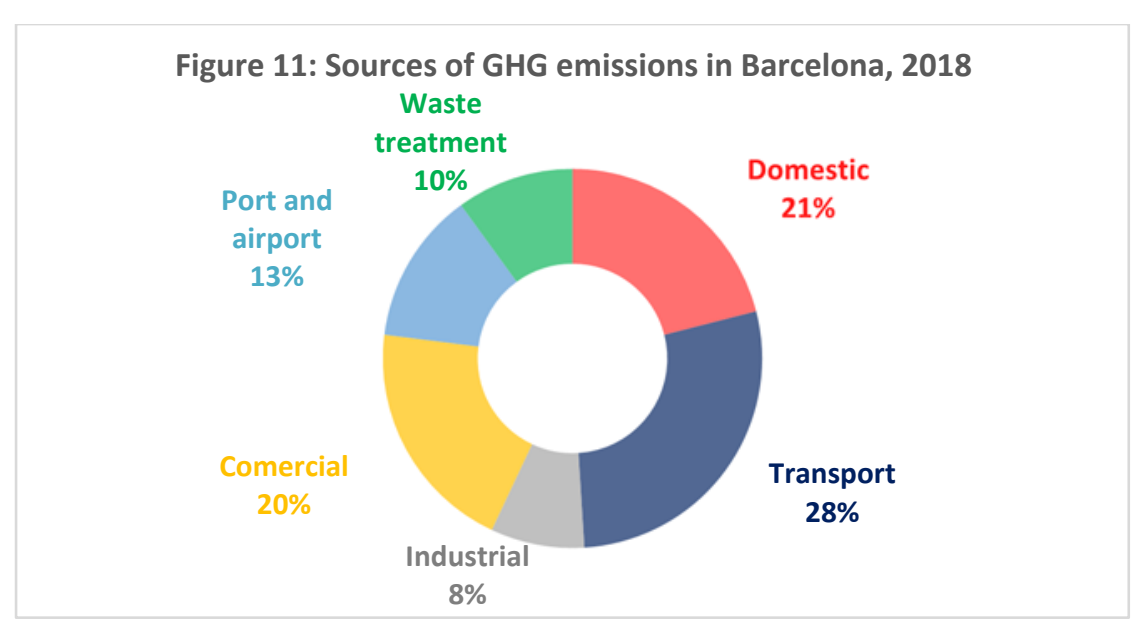

Source: Own illustration based on data by Barcelona's Energy Agency (Agència d'Energia de Barcelona, 2020).

As compared to other European cities, emissions per capita in Barcelona are very low. According to data provided by the C40 Cities Climate Leadership Group (2020) Barcelona is the city with the lowest GHG emissions per capita in Europe $\left(1,7\right.$ t CO2eq / inhabitant ${ }^{11}$ whereas Madrid generates 3.1 $\mathrm{t}$ CO2eq / inhabitant and Venice even reaches levels up to $11.8 \mathrm{t} \mathrm{CO2eq} \mathrm{/} \mathrm{inhabitant}{ }^{12}$ ). Partially, that can be explained by a relatively high share of nuclear energy in Catalonia's electricity mix ( $>51 \%)$ (Agència d'Energia de Barcelona, 2020).

In the context of the 2015 United Nations Climate Change Conference in Paris, Barcelona has committed to reducing its GHG emissions per capita by $40 \%$ by 2030 compared to 2005 levels (Ajuntament de Barcelona, 2018). Barcelona's climate plan outlines how the City wants to reach this goal. One of 18 lines of action is improving urban mobility (in line with the City's Urban Mobility Plan 2024 mentioned above) with a combination of measures to reduce mobility, distribute it more evenly over the day, and to promote less-polluting ways of mobility, e.g. individual motorized transport shall be reduced by $20 \%$. Measures presented include extending the cycling network, connecting tramlines and creating more bus lanes, creating 'park \& ride' zones together with other municipalities, improving the infrastructure for electric vehicles, and electrifying the City's vehicle fleet, creating more superblocks, and promoting the development of business mobility plans (Ajuntament de Barcelona, 2018).

\section{Results and discussion: Changes since the pandemic}

\subsection{Changes in mobility behaviour}

This section illustrates observed changes in mobility since the beginning of the pandemic and provides potential explanations for those changes. It also provides indications of citizens' general preferences in urban mobility to better understand mobility choices.

\footnotetext{
${ }^{11}$ C40 data for Barcelona differs from data presented by Barcelona's Energy Agency, which might be due to a different calculation method. However, even with the higher value presented by Barcelona's Energy Agency Barcelona's emission per capita are comparatively low.

${ }^{12}$ Based on latest available data for each city, therefore years might vary.
} 
Behavioural changes in urban mobility in Barcelona due to the COVID-19 pandemic and its impact on air pollution and greenhouse gas emissions

Corinna Peters

With the start of the lockdown in March 2020 mobility in Barcelona has reduced drastically for all means of transport, dropping by about $90 \%$ compared to pre-pandemic levels (Ajuntament de Barcelona, 2021d). Data from Google's Community Mobility Reports confirm the 90\% drop in mobility, showing however that the reduction was less pronounced for trips to pharmacies and grocery stores (Google, 2021). ${ }^{13}$ Having an economy dominated by the service sector - similar to other urban areas in Europe - Barcelona was able to keep up its basic functions while reducing traffic significantly, at least for a short period of time (Ajuntament de Barcelona, 2018; Baldasano, 2020).

Figure 12 below shows the change of road traffic and public transport from March to December in 2020 compared to levels in February (the baseline). In May 2020, with the ease of lockdown restrictions, road traffic and public transport started to recover, then taking the usual dip during the summer break in August and another one towards the end of the year when tighter COVID restrictions were imposed. Most remarkably, the use of bicycles has surged to levels $50 \%$ higher than pre-pandemic levels in June and even exceeding $60 \%$ in November. As there is no comparable data available for other years, it is difficult to assess how this result compares to previous years. One can observe a clear pattern of spikes on weekends and public holidays (all levels above $20 \%$ increase compared to pre-pandemic levels occurred on weekends or public holidays), i.e. the increase in bicycle usage during the pandemic is especially high on weekends as compared to weekends in February. On the contrary, usage of cars and motorcycles do not show such notable spikes and remain below the pre-pandemic baseline throughout most of the year. Only on a few days in July, September and October usage of motorcycles have reached levels comparable to February (see Figure 12 below).

Public transport has been hit hardest by the pandemic with significant lower demand as compared to February levels throughout the year. Demand almost returned to pre-pandemic levels in October, but then dropped again to close the year at demand levels $40 \%$ lower than in February.

\footnotetext{
${ }^{13}$ With the start of the pandemic Google has published mobility data at community level (Google, 2021). Unlike traffic intensity data provided by the City Council of Barcelona, this data shows not just the reduction in mobility, but also the destination of trips (see Appendix, Google Community Report Barcelona).
} 
Behavioural changes in urban mobility in Barcelona due to the COVID-19 pandemic and its impact on air pollution and greenhouse gas emissions

Figure 12: Change in traffic, Barcelona, 2020

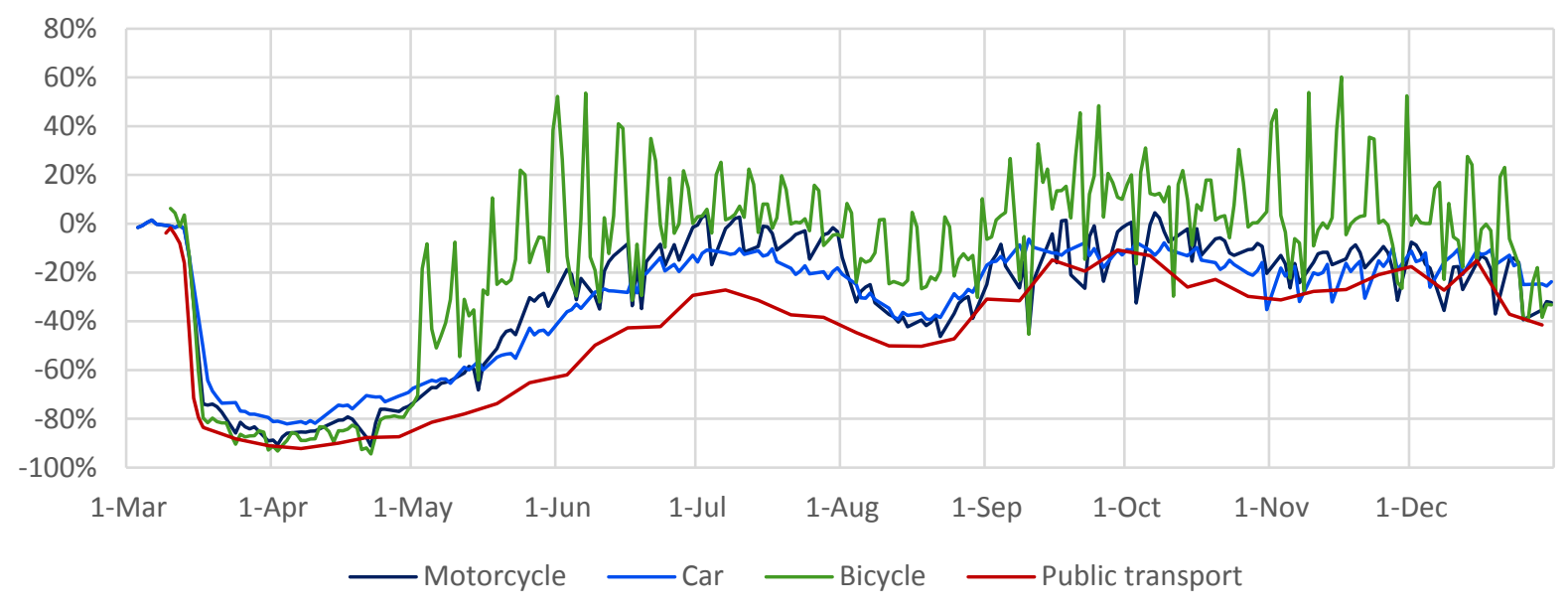

Source: Own illustration based on data from ATM and the City Council of Barcelona (Ajuntament de Barcelona, 2021a; Autoritat del Transport Metropolità, 2020; Autoritat del Transport Metropolità de Barcelona, 2021; R. Rios (Ajuntament de Barcelona), personal communication, January $\left.18^{\text {th }}, 2021\right)$.

Note: 1) The City Council of Barcelona obtains data on road traffic (motorcycles, cars and bicycles) through several measurement stations across the city, which monitor the intensity of traffic on bike lanes and traffic lanes. To distinguish between motorcycles and cars the stations read the license plates, and vehicles can be classified based on the vehicle registration at the city's General Directorate of Traffic (R. Rios, personal communication, January $18^{\text {th }}, 2021$ ).

2) The data shows how traffic intensity on that day compares to traffic intensity on a baseline day in February. A baseline day represents a February value for that day of the week, e.g. traffic intensity on a Monday in April will be compared to traffic intensity on a Monday in February (R. Rios, personal communication, January $18^{\text {th }}, 2021$ ).

3) Data on public transport is provided by Barcelona's Transport Authority (ATM). It measures the demand for public transport in terms of number of ticket validations. It indicates weekly data, and is therefore not directly comparable to road traffic data. Nevertheless, it shows the trend in demand reduction.

4) Data for walking was not available.

Complementing this public data on traffic intensity, the online survey with 100 participants shows similar trends in behavioural changes. Survey respondents were asked, 'How often did you use the following modes of transport on average per week before the pandemic (before March 2020) including travel for work and any other type of travel (round trip counts as one trip)? ${ }^{\prime 14}$ and the same for the last month (November or December 2020). Public transport has seen the highest share of respondents using it less frequently in November and December 2020 than before the pandemic (see Figure 13 below). Also, a relatively high share of respondents (22\%) reported to walk less often. Cycling and driving a car has increased the most with $18 \%$ and $20 \%$ of the participants responding that they use this means of transport more often than before the pandemic.

${ }^{14}$ Translated to English from the original survey question in Spanish. See Appendix, Questionnnaire online survey for original question. 
Universidad de Barcelona

Behavioural changes in urban mobility in Barcelona due to the COVID-19 pandemic and its impact on air pollution and greenhouse gas emissions

Corinna Peters

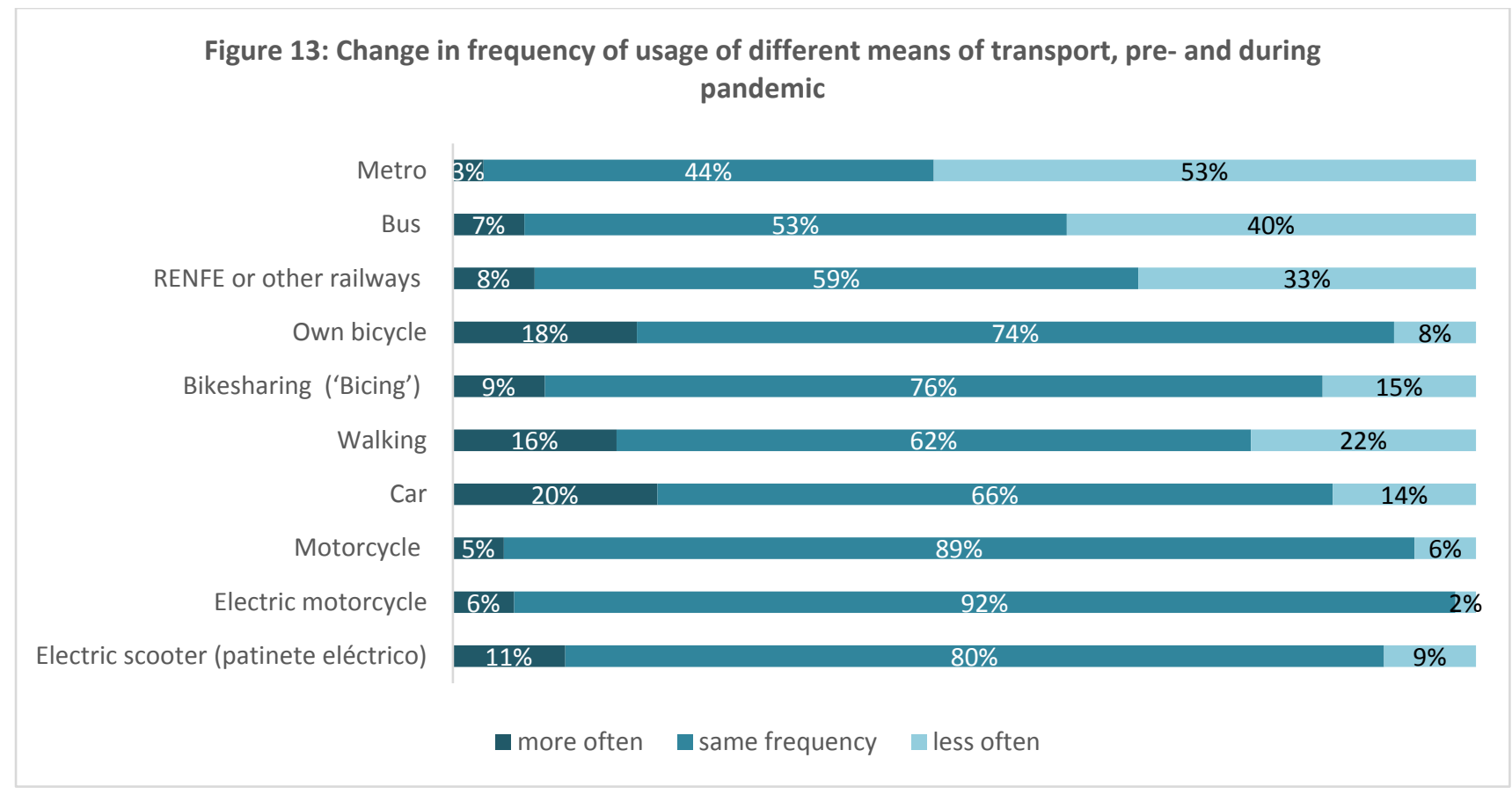

Source: Own illustration based on results of online survey of 100 participants, comparing results for question 2, 4 and 12 (see Appendix, Questionnaire online survey).

Although these findings are consistent across different social categories, there are two tendencies that stand out when looking at responses across different age groups: i) $45 \%$ of 36 - to 45 -year-old respondents reported that they cycle more often now than before the pandemic. This is by far the highest share regarding an increase in bicycle usage (see Figure 14 below). ${ }^{15}$ ii) $38 \%$ of participants older than 45 years of age stated that they use a car more often than before the pandemic. This is also the highest share across all age groups (see Figure 15 below). The data collected through the online survey does not indicate potential reasons for these tendencies.

\footnotetext{
${ }^{15}$ A regression analysis (Ordinary Least Squares (OLS)) was conducted to estimate which factors could help explain the reported increase of usage of a certain means of transport, with factors included being age, gender, education level, gender, occupation, income level, whether the respondent uses a car and whether the respondent was a resident of Barcelona. However, results were mostly statistical insignificant due to low variability. Low variability could imply that participants across the social categories share similar ideas and preferences regarding urban mobility. One factor that was statistically significant and positively correlated with cycling more often was being within the age group of 36 to 45 . Results are presented in Table 13 in the Appendix, Results of regression analysis.
} 
Behavioural changes in urban mobility in Barcelona due to the COVID-19 pandemic and its impact on air pollution and greenhouse gas emissions
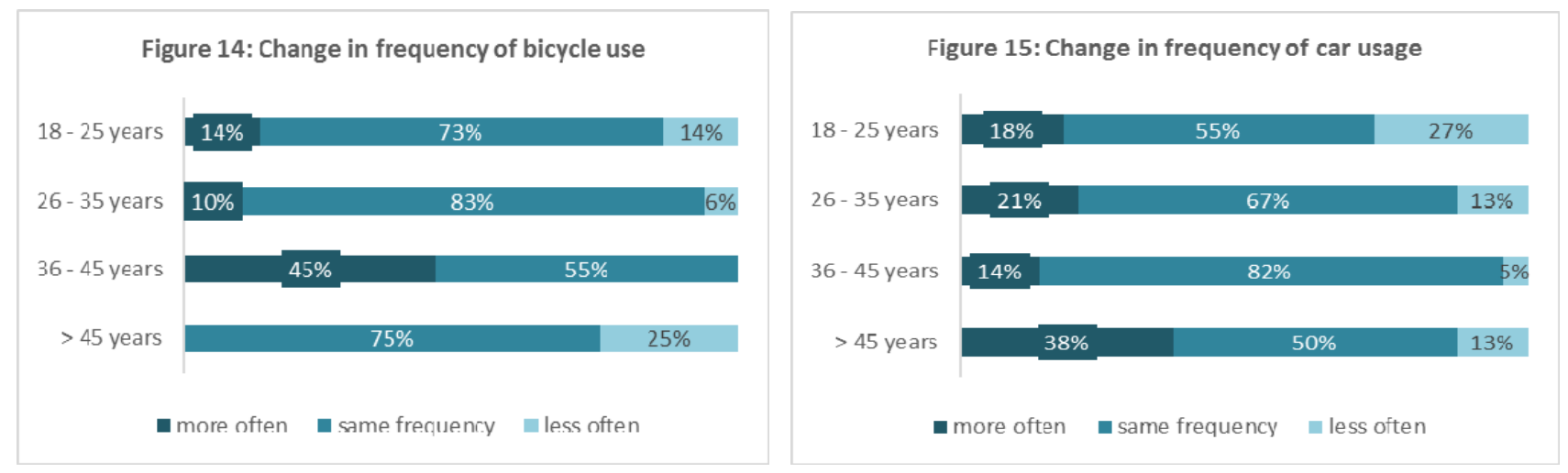

Source: Own illustration based on results of online survey of 100 participants, comparing results for question 2 and 4 (see Appendix, Questionnaire online survey).

The most frequently reported reason for having changed one's behaviour was to avoid the risk of infecting oneself with COVID-19 (more than 60\% of respondents) (see Table 9 in Appendix, Results of online survey, for detailed descriptive statistics). The same holds true across almost all social categories, like gender, age, education level, income and occupation. The second most cited reason was 'working/studying (more) from home' $(44 \%)$, followed by 'avoiding risk of infecting others' (36\%). $17 \%$ of respondents reported not to have changed their mobility behaviour.

Although 'avoiding the risk of infecting oneself with COVID-19' was the most cited reason for changes in mobility behaviour during the pandemic, it was not the most important factor influencing the participants choice of transport in general. When asked about the most important factors for choosing a mode of transport, participants ranked 'low risk of COVID-19 infection' only the 5th most important factor (see Figure 16 below). The most relevant reported factor was getting fast to one's destination, followed by convenience, affordability, and reliability. Travelling environmentally friendly was given relatively low importance, with only $14 \%$ of respondents ranking it among their top three factors for choosing a mode of transport. 
Behavioural changes in urban mobility in Barcelona due to the COVID-19 pandemic and its impact on air pollution and greenhouse gas emissions

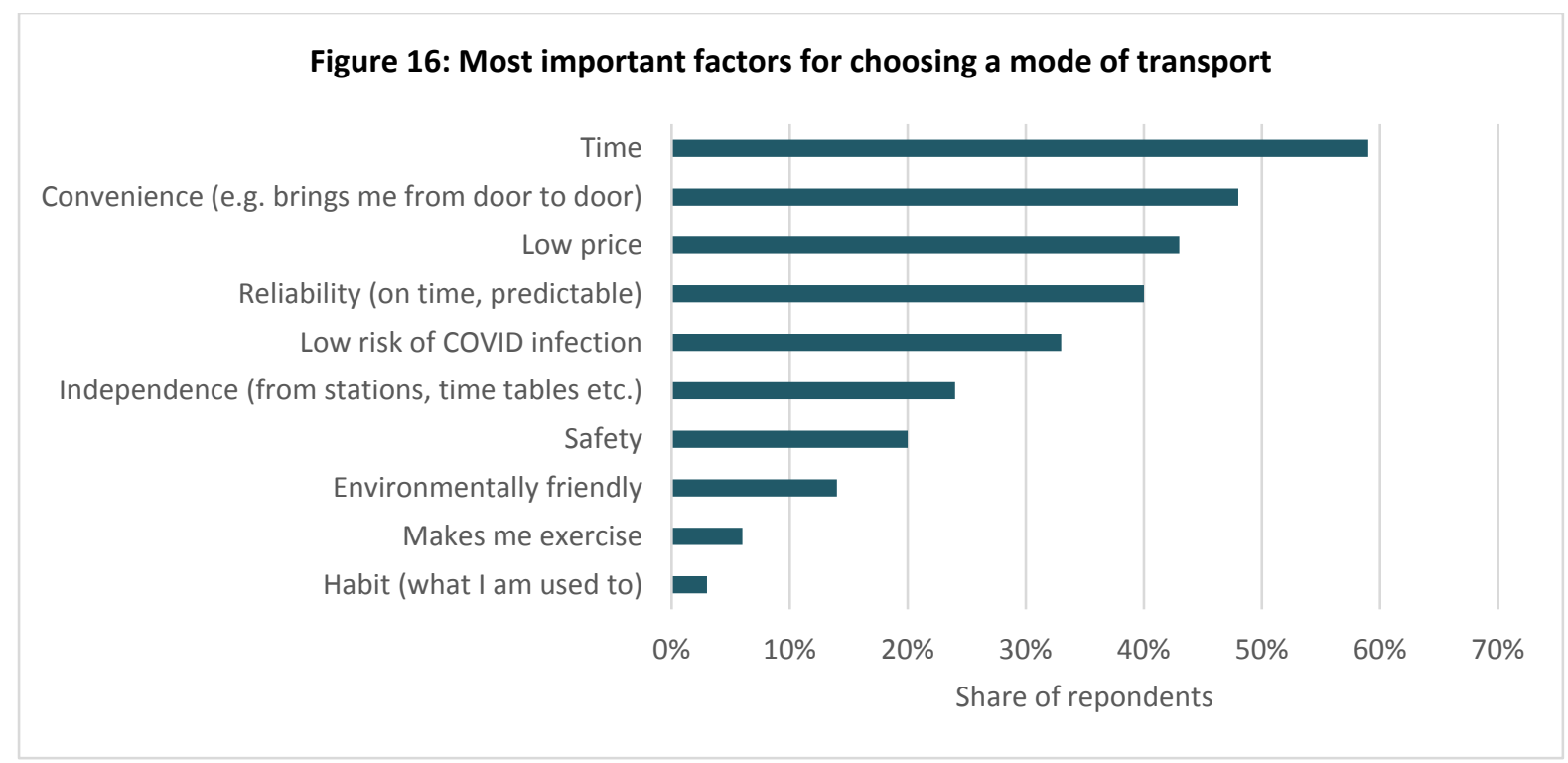

Source: Own illustration based on survey results of 100 participants.

Note: Participants were able to choose up to three reasons, therefore the sum of percentages is more than $100 \%$.

When asked why they do not cycle (more) frequently, respondents reported most often that they did not have a bicycle, accounting for $40 \%$ of respondents. This was the top reason for not cycling (more) across almost all social categories and was particularly noticeable among respondents of the youngest age group (18-25 years), the unemployed, the lowest income group ( $<800 \mathrm{EUR} / \mathrm{month}$ ) and the respondents with secondary education. $30 \%$ of participants replied that they did not cycle when the weather was bad, and $23 \%$ responded that they did not have a subscription with the bike sharing service 'Bicing'. This reason is closely followed by 'feeling unsafe cycling next to cars' (22\%). 'Having to carry (transport) things' (20\%), 'long distance to destination' (19\%), and 'not finding a safe parking space for the bicycle' (13\%) were also reported as relevant reasons for not cycling (more often) (see Figure 17 below and Table 10 in Appendix, Results of online survey, for detailed descriptive statistics). 
Behavioural changes in urban mobility in Barcelona due to the COVID-19 pandemic and its impact on air pollution and greenhouse gas emissions

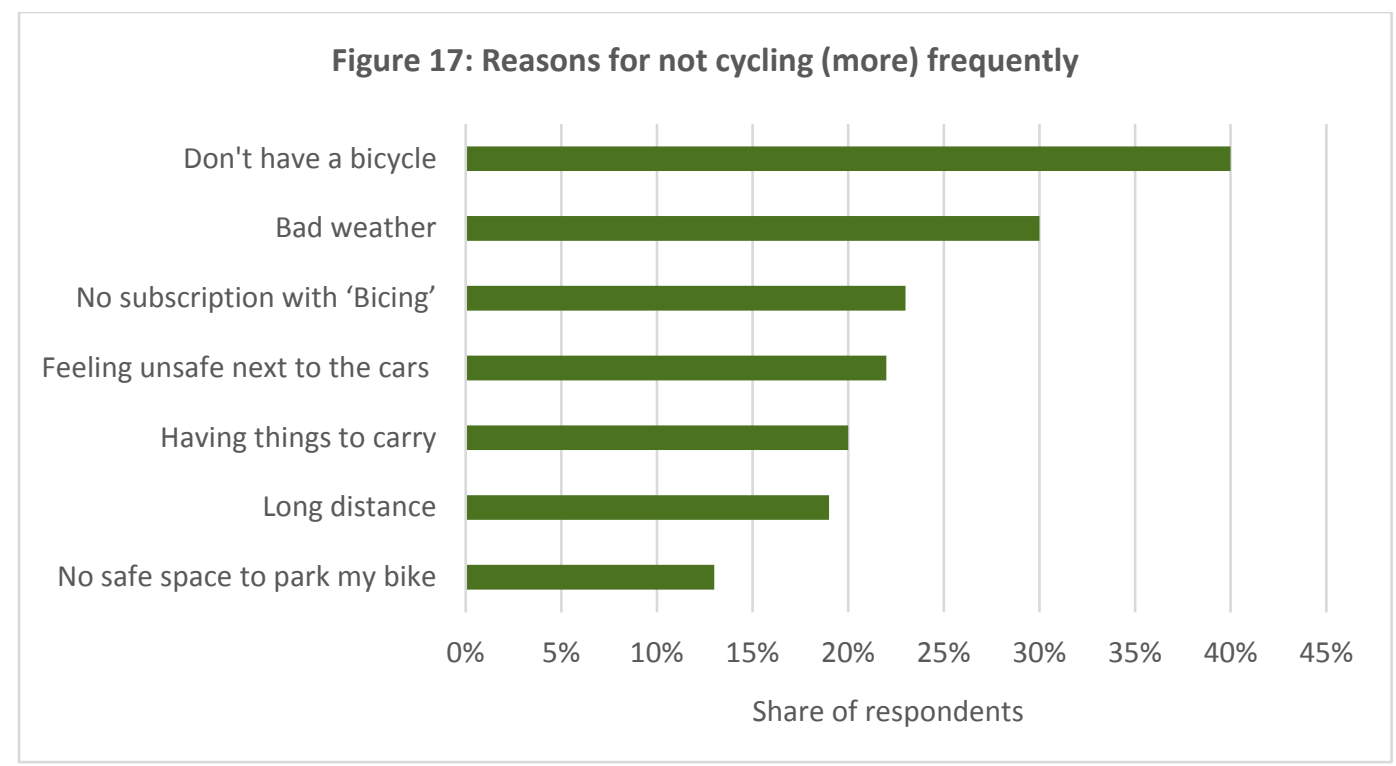

Source: Own illustration based on survey results of 100 participants, question 8.

Note: Participants were able to choose several reasons, therefore the sum of percentages is more than $100 \%$.

When asked 'Why do you not walk (more often) instead of using an alternative mode of transport?' ${ }^{16}$, survey respondents most often reported 'long distance to destination' as a reason for choosing not to walk (52\% of respondents). This was also true across most social groups (Table 11 in Appendix, Results of online survey, for detailed descriptive statistics). As for cycling, 'bad weather' was the second most cited reason. This was followed by 'having things to carry' (37\%) and 'feeling unsafe in the certain parts of the city' (25\%). 'Feeling uncomfortable next to cars' (5\%) did not seem to play a major role for respondents' decision whether to walk or not (see Figure 18 below).

${ }^{16}$ Translated from the original survey question in Spanish. See Appendix, Questionnnaire online survey for original question. 
Behavioural changes in urban mobility in Barcelona due to the COVID-19 pandemic and its impact on air pollution and greenhouse gas emissions

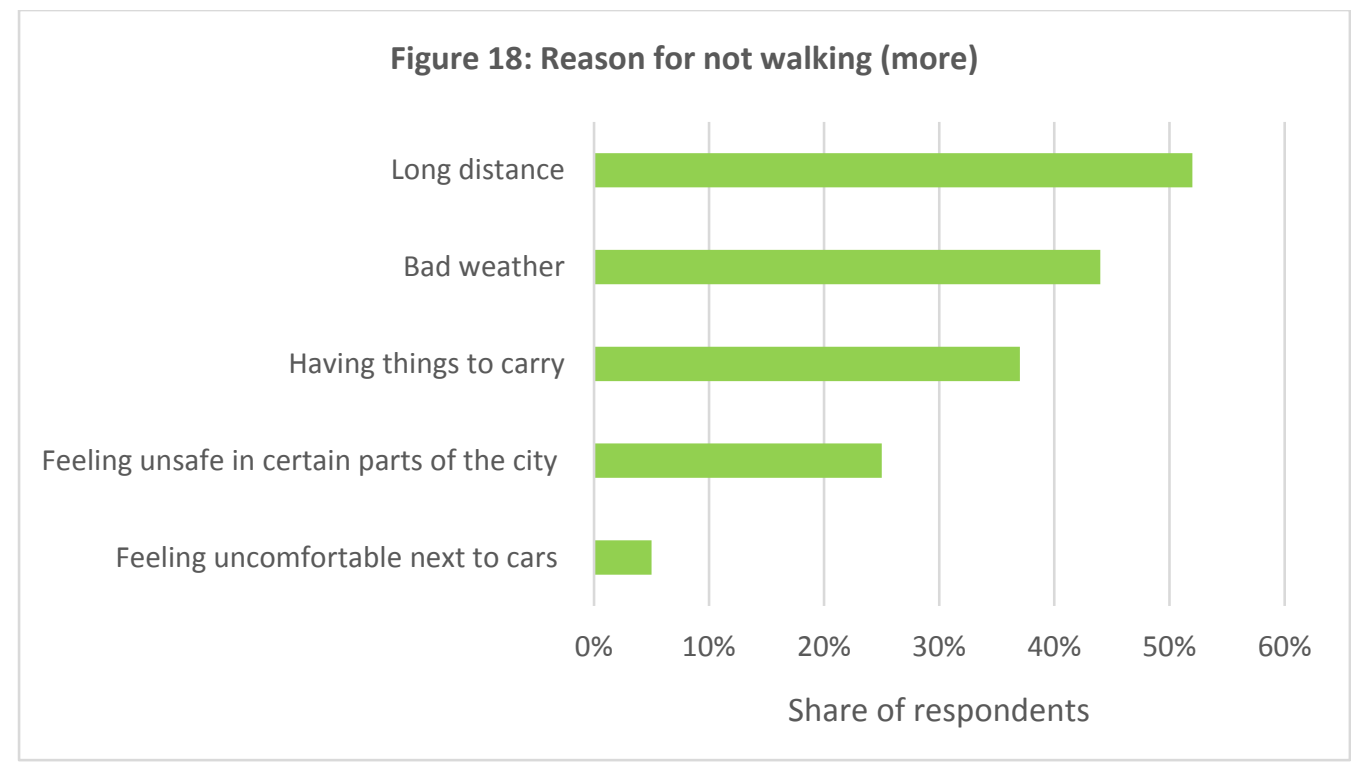

Source: Own illustration based on survey results, question 9.

Note: Participants were able to choose as multiple reasons, therefore the sum of percentages is more than $100 \%$.

One of the core challenges for urban planners, and even more so for planners in public transport, is to estimate how urban mobility will develop in the coming months and years (Ajuntament de Barcelona, 2021b). Xavier Sanyer, Head of Mobility Services of Barcelona's Transport Authority (ATM), stated:

"There is a high uncertainty about how behavioural change during the pandemic will affect us in the future. Will people go back to their pre-pandemic habits? Will people work more often from home than before the pandemic? Will people keep buying most products online? We have to make our planning under these uncertain conditions without knowing how demand will develop." $X$. Sanyer, personal communication, 18.01.2021).

In the survey for this present study, respondents were asked whether they believe they will use each mode of transport equally, more or less than before the pandemic, once the pandemic is over. As Figure 19 below illustrates the majority of participants responded that they believe they will return to pre-pandemic mobility behaviours after the pandemic. Nevertheless, there seems to be a tendency towards more private transport, with $37 \%$ of respondents stating they would use a car more often, followed by $24 \%$ reporting they will use their own bicycle more frequently, $20 \%$ for an increased motorcycle use, and $19 \%$ stated they will use 'Bicing' more often. Also, the share of participants stating that they would use less public transport are the highest. 
Behavioural changes in urban mobility in Barcelona due to the COVID-19 pandemic and its impact on air pollution and greenhouse gas emissions

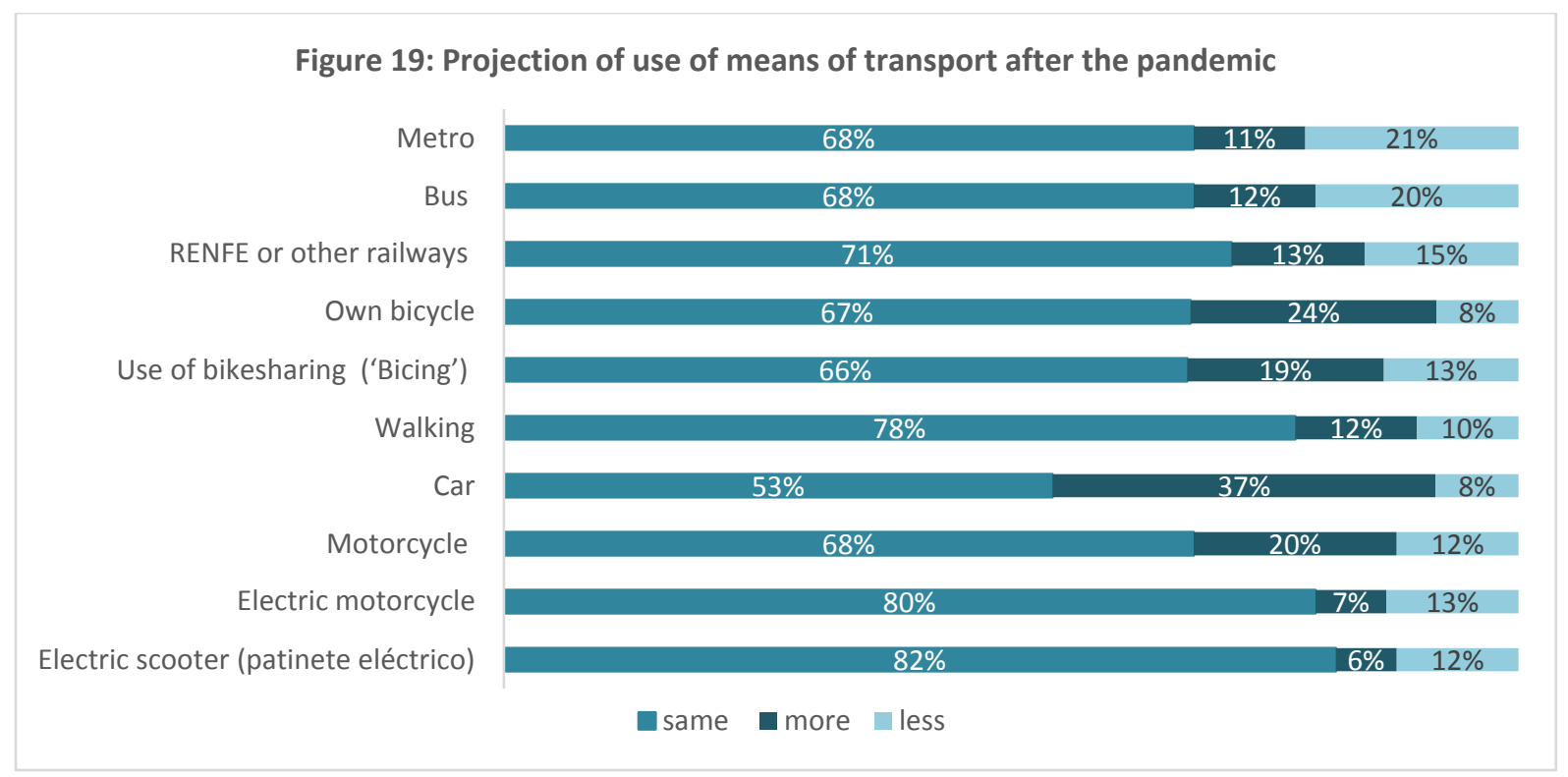

Source: Own illustration based on results of online survey, question 10.

Lastly, participants of the survey were asked how much they agreed (or disagreed) with select urban mobility policies in Barcelona. Most agreement among respondents concerned a wish for improving public transport (92\% agree or strongly agree). There was also a high support for promoting climate friendly means of transport (77\% agree or strongly agree). Participants also mostly agreed with extending pedestrian areas and the cycling network, while reducing car space ( $74 \%$ and $72 \%$ agree or strongly agree). Measures to increase car space triggered a more controversial response. While more participants disagreed that car space should extended (48\% disagreed or strongly disagreed), there was also a substantial share of participants who agreed or strongly agreed (42\%) (see Figure 20 below). The trends were mostly consistent across all social categories (see Table 12 in the Appendix, Results of online survey, for detailed descriptive statistics). The data suggests that participants tend to agree with the City's vision towards more climate friendly mobility. However, given the small number of participants and the limited detail of this question, this result is rather to be interpreted as an indication for further research on citizens' preferences regarding urban mobility policy. 
Behavioural changes in urban mobility in Barcelona due to the COVID-19 pandemic and its impact on air pollution and greenhouse gas emissions

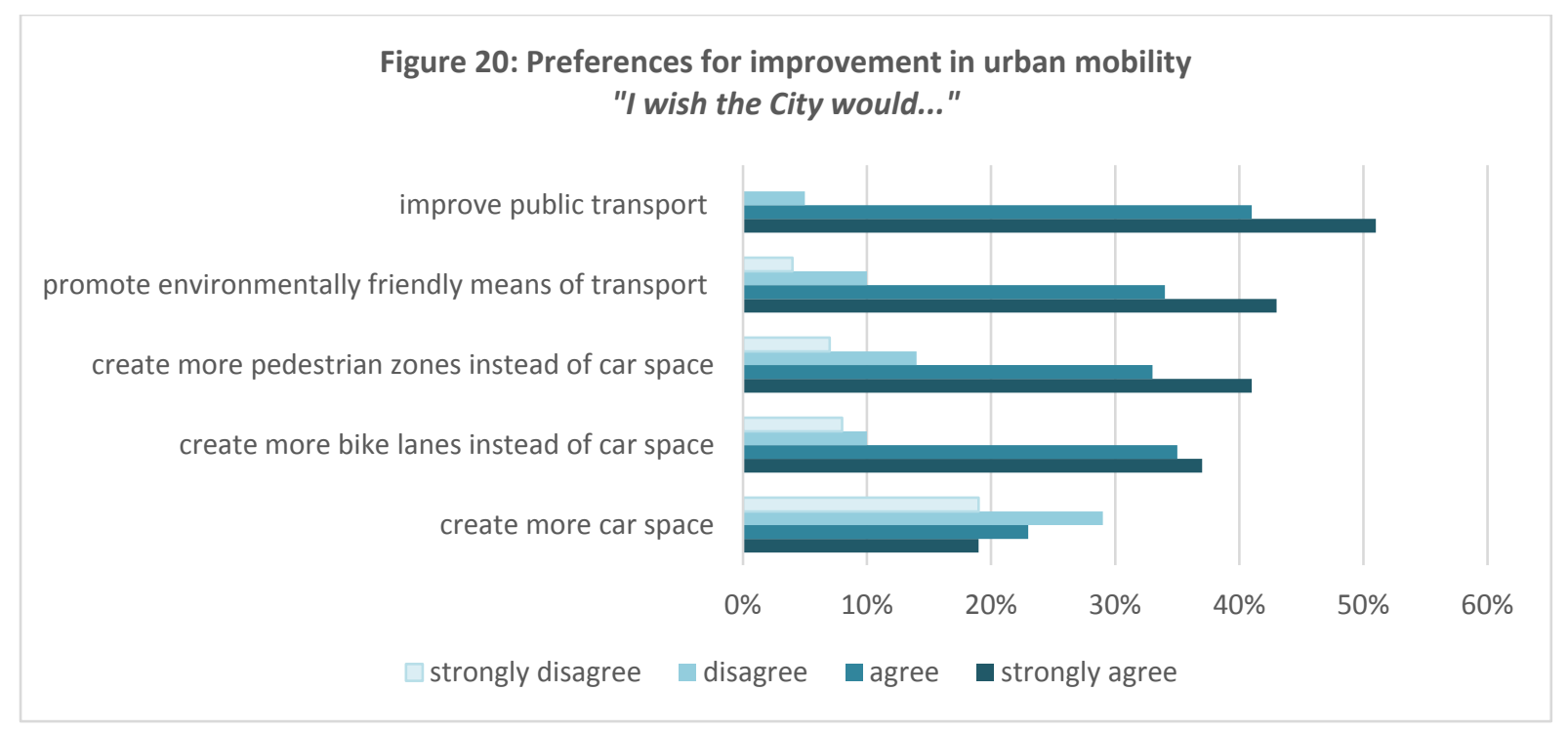

Source: Own illustration based on results of online survey, question 11.

\subsection{Changes in emissions}

Changes in air quality

This section elaborates how air quality has developed since the start of the pandemic and compares NO2 and PM10 levels in 2020 to the year before.

Given the reduction in mobility, air pollution in Barcelona has decreased significantly during the pandemic. Especially during the strict lockdown from March to June concentration of most air pollutants has dropped to very low levels (Generalitat de Cataluña, 2020a). A study conducted in April 2020 estimated that the most significant reduction during the first two weeks of the lockdown was for black carbon and NO2 (-45 to $-51 \%)$, pollutants mainly related to traffic emissions. A lower reduction was observed for PM10 (-28 to $-31.0 \%)$ probably due to a significant regional contribution and the prevailing secondary origin of fine aerosols. By contrast, $\mathrm{O} 3$ levels increased $(+33$ to $+57 \%$ of the $8 \mathrm{~h}$ daily maxima), probably because of lower titration of $\mathrm{O} 3$ by NO and the decrease of NOx. There was no clear trend identified for the low SO2 levels (Tobías et al., 2020).

Figure 21 below shows daily concentrations of $\mathrm{NO} 2$ and PM10 averaged across all measuring stations in Barcelona. After a considerable decrease in NO2 and PM10 levels in March 2020 one can observe a clear upward trend from June 2020 onwards. Nevertheless, average concentration for the last quarter of the year are below levels of 2019 (see Table 4 below). The increase is more noticeable in NO2 than in PM10 which confirms NO2's strong correlation with road traffic. 
Behavioural changes in urban mobility in Barcelona due to the COVID-19 pandemic and its impact on air pollution and greenhouse gas emissions

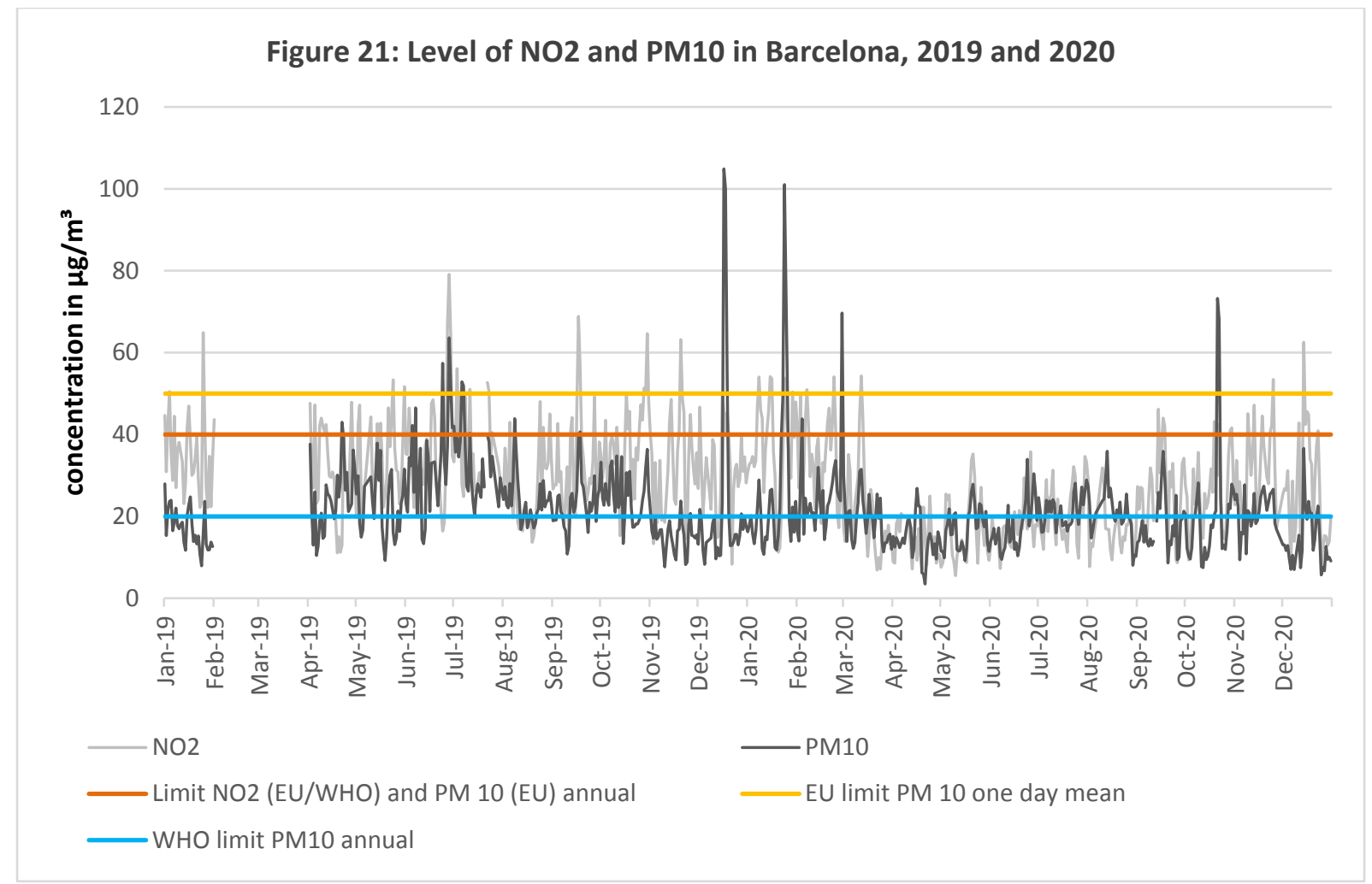

Source: Own illustration based on data provided by the City Council of Barcelona (Ajuntament de Barcelona, 2020c). Note: Data for February and March 2019 were not available. Outliers with PM10 levels higher than 1,000 $\mu \mathrm{g} / \mathrm{m}^{3}$ have been deleted. This effected 3 hourly measurements in Vall Hebron on the 20.07.2019. Such high levels seem very unlikely in an outdoor environment based on the analysis by the WHO (World Health Organization, 2005) and given that no city presented by the World Air Quality Index measured levels above $1,000 \mu \mathrm{g} / \mathrm{m}^{3}$, which includes highly polluted urban areas in China and India (World Air Quality Index, 2021).

There are significant spikes in PM10 reaching daily average concentrations of more than $100 \mu \mathrm{g} / \mathrm{m}^{3}$ on two days during the last two years (17 and 18th December 2019, and 24th January 2020). Since the COVID-19 pandemic, PM10 concentrations have not reached such high levels, but surged to 68 and $73 \mu \mathrm{g} / \mathrm{m}^{3}$ on 21 and 22 of October 2020. The concentrations exceed by far the WHO and EU limit for one day mean levels $\left(50 \mathrm{\mu g} / \mathrm{m}^{3}\right)$. However, the EU allows levels higher than the limit for up to 35 days during a year (Directive 2008/50/EC, 2008). Therefore, PM10 levels were higher than WHO recommendations, but complying with EU legislation. NO2 levels do not show such prominent spikes but reached high concentrations above $60 \mu \mathrm{g} / \mathrm{m}^{3}$ on seven days in 2019 and one in 2020 (14th December). What caused these surges in PM10 and NO2 levels would require further investigation that is beyond this present study. However, according to the WHO long-term exposure to air pollution is more relevant for human health than short-term exposure even to high levels (World Health Organization, 2005). Therefore, this study will focus on annual mean levels.

The annual mean concentrations have reached historical lows in 2020. PM10 concentrations were at $19,2 \mu \mathrm{g} / \mathrm{m}^{3}$ (-20\% compared to 2019) complying with the WHO guideline $\left(20 \mathrm{\mu g} / \mathrm{m}^{3}\right)$ for the first time in at least 20 years (Agència De Salut Pública Barcelona, 2020; Ajuntament de Barcelona, 2020c). NO2 annual mean was $23,9 \mu \mathrm{g} / \mathrm{m}^{3}$ ( $28 \%$ lower than last year) thereby complying with WHO and EU limits 
Behavioural changes in urban mobility in Barcelona due to the COVID-19 pandemic and its impact on air pollution and greenhouse gas emissions

$\left(40 \mathrm{\mu g} / \mathrm{m}^{3}\right)$. In particular the lockdown period showed a massive reduction in NO2 and PM10 concentrations compared to the same period in 2019 (see Table 4 below).

Table 4: PM10 and NO2 levels for 2019 and 2020 averaged across all measuring stations in Barcelona

\begin{tabular}{|l|c|c|c|c|c|c|}
\hline & 2019 & 2020 & DIFF & $\begin{array}{c}\text { Since } 14 \text { th } \\
\text { March } 2020\end{array}$ & $\begin{array}{c}\text { EU } \\
\text { Limit }\end{array}$ & $\begin{array}{c}\text { WHO } \\
\text { limit }\end{array}$ \\
\hline Annual mean PM10 in $\mu \mathrm{g} / \mathrm{m}^{3}$ & $24 \mu \mathrm{g} / \mathrm{m}^{3}$ & $19 \mu \mathrm{g} / \mathrm{m}^{3}$ & $-20 \%$ & Not applicable & $\begin{array}{c}40 \\
\mu \mathrm{g} / \mathrm{m}^{3}\end{array}$ & $\begin{array}{c}20 \\
\mu \mathrm{g} / \mathrm{m}^{3}\end{array}$ \\
\hline Annual mean NO2 in $\mu \mathrm{g} / \mathrm{m}^{3}$ & $33 \mu \mathrm{g} / \mathrm{m}^{3}$ & $24 \mu \mathrm{g} / \mathrm{m}^{3}$ & $-28 \%$ & Not applicable & $\begin{array}{c}40 \\
\mu \mathrm{g} / \mathrm{m}^{3}\end{array}$ & $\begin{array}{c}40 \\
\mu \mathrm{g} / \mathrm{m}^{3}\end{array}$ \\
\hline Mean PM10 April - 22 June & $25 \mu \mathrm{g} / \mathrm{m}^{3}$ & $16 \mu \mathrm{g} / \mathrm{m}^{3}$ & $-38 \%$ & Not applicable & - & - \\
\hline Mean NO2 April - 22 June & $32 \mu \mathrm{g} / \mathrm{m}^{3}$ & $16 \mu \mathrm{g} / \mathrm{m}^{3}$ & $-51 \%$ & Not applicable & - & - \\
\hline Mean PM10 Oct - Dec & $21 \mu \mathrm{g} / \mathrm{m}^{3}$ & $18 \mu \mathrm{g} / \mathrm{m}^{3}$ & $-13 \%$ & Not applicable & - & - \\
\hline Mean NO2 Oct - Dec & $34 \mu \mathrm{g} / \mathrm{m}^{3}$ & $28 \mu \mathrm{g} / \mathrm{m}^{3}$ & $-18 \%$ & Not applicable & - & - \\
\hline No. days PM10 $>50 \mu \mathrm{g} / \mathrm{m}^{3}$ & 8 & 4 & $-50 \%$ & 2 & $35 \mathrm{days}$ & $0 \mathrm{days}$ \\
\hline Highest one day mean PM10 in $\mu \mathrm{g} / \mathrm{m}^{3}$ & $105 \mu \mathrm{g} / \mathrm{m}^{3}$ & $101 \mu \mathrm{g} / \mathrm{m}^{3}$ & $-4 \%$ & $73 \mu \mathrm{g} / \mathrm{m}^{3}$ & - & $\begin{array}{c}50 \\
\text { Highest one day mean NO2 in } \mu \mathrm{g} / \mathrm{m}^{3}\end{array}$ \\
\hline
\end{tabular}

Source: Own illustration based on data provided by the City Council of Barcelona (Ajuntament de Barcelona, 2020c).

Note: Green shaded cells imply compliance with WHO and EU limits. Yellow shaded cells mean that values are compliant with EU limits, but not with WHO guidelines.

Overall, pollution levels in different parts of Barcelona follow a similar pattern as the Barcelona average (as displayed in Figure 21 above) with a significant reduction in pollution levels in 2020 as compared to the year before. Table 5 below shows the changes in PM10 levels at different measuring stations. Noticeably, the annual mean concentrations measured in Vall Hebron and Palau Reial have dropped by $40 \%$ and $38 \%$ respectively to below $20 \mu \mathrm{g} / \mathrm{m}^{3}$, therewith complying with the WHO guidelines. PM 10 levels in Eixample, Gràcia and Poblenou have also decreased, though to a lesser extent and remaining above the WHO limit (see Table 5 below). The number of days with a mean concentration of more than $50 \mu \mathrm{g} / \mathrm{m}^{3}$ has reduced the most in Poblenou and Vall Hebron, whereas remaining (almost) constant in Eixample, Gràcia and Palau Reial. 
Universidad de Barcelona

Behavioural changes in urban mobility in Barcelona due to the COVID-19 pandemic and its impact on air pollution and greenhouse gas emissions

Corinna Peters

Table 5: Changes in PM10 levels 2019 to 2020 across different measuring stations

\begin{tabular}{|l|c|c|c|c|c|}
\hline & Eixample & Gràcia & Poblenou & Vall Hebron & Palau Reial \\
\hline $\begin{array}{l}\text { Annual mean in } \mu \mathrm{g} / \mathrm{m}^{3} \\
2019\end{array}$ & 26,3 & 23,4 & 28,8 & 25,6 & 26,3 \\
\hline $\begin{array}{l}\text { Annual mean in } \mu \mathrm{g} / \mathrm{m}^{3} \\
2020\end{array}$ & 23,5 & 21,6 & 25,8 & 15,4 & 16,3 \\
\hline DIFF & $-11 \%$ & $-8 \%$ & $-10 \%$ & $-40 \%$ & $-38 \%$ \\
\hline $\begin{array}{l}\text { No of days with mean } \\
\text { levels > 50 } \mu \mathrm{g} / \mathrm{m}^{3} 2019\end{array}$ & 8 & 6 & 21 & 16 & 3 \\
\hline $\begin{array}{l}\text { No of days with mean } \\
\text { levels }>50 \mu \mathrm{g} / \mathrm{m}^{3} 2020\end{array}$ & 8 & 5 & 7 & 5 & 3 \\
\hline $\begin{array}{l}\text { Highest measured value in } \\
\mu \mathrm{g} / \mathrm{m}^{3} 2019 \text { (across all } \\
\text { stations) }\end{array}$ & 564 & - & - & - & - \\
\hline $\begin{array}{l}\text { Highest measured value in } \\
\mu \mathrm{g} / \mathrm{m}^{3} \text { 2020 (across all } \\
\text { stations) }\end{array}$ & - & 516 & - & \\
\hline
\end{tabular}

Source: Own illustration based on data provided by the City Council of Barcelona (Ajuntament de Barcelona, 2020c).

Note: 1) No data was available for the stations Sants and Ciutadella. 2) Another station ("58" with unspecified location) showed measurement data, but only starting in November of 2019 therefore data was not included in this table. 3) Green shaded cells imply compliance with WHO and EU limits. Yellow shaded cells mean that values are compliant with EU limits, but not with WHO guidelines. 4) The last two rows only display the highest valued measured throughout the year at any station. Hence, only one cell per row shows a value.

Table 6 shows the changes in NO2 levels from 2019 to 2020 at different measuring stations. Annual mean concentrations have decreased by 18 to $29 \%$ across all measuring stations. In 2020 even the two high transit areas Eixample and Gràcia complied with WHO/EU limits (Ajuntament de Barcelona, 2020c).

In 2019, the concentration of NO2 surpassed the one-hour EU/WHO limit of $200 \mu \mathrm{g} / \mathrm{m}^{3}$ on three occasions, therewith still complying with the EU Directive which allows this limit to be exceeded up to 18 times during a year. In 2020, there was no measurement beyond the $200 \mu \mathrm{g} / \mathrm{m}^{3}$ limit with the highest value being $145 \mu \mathrm{g} / \mathrm{m}^{3}$ measured in Ciutadella (see Table 6 below).

Apart from recommendations for daily means and hourly spikes the WHO also recommends an alert threshold for NO2 $\left(400 \mu \mathrm{g} / \mathrm{m}^{3}\right)$. Measurements beyond that limit should trigger an alert response mechanism, such as limiting traffic and urging citizen in that area to stay home, if possible (World Health Organization, 2005). Such high concentration has not been reached for any measurement at any measuring station neither in the year 2019 nor in 2020 (Ajuntament de Barcelona, 2020c). 
Universidad de Barcelona

Behavioural changes in urban mobility in Barcelona due to the COVID-19 pandemic and its impact on air pollution and greenhouse gas emissions

Corinna Peters

Table 6: Change in NO2 levels 2019 and 2020 at different measuring stations

\begin{tabular}{|c|c|c|c|c|c|c|c|}
\hline & Eixample & Gràcia & Poblenou & Sants & $\begin{array}{l}\text { Vall } \\
\text { Hebron }\end{array}$ & $\begin{array}{l}\text { Palau } \\
\text { Reial }\end{array}$ & Ciutadella \\
\hline $\begin{array}{l}\text { Annual mean in } \mu \mathrm{g} / \mathrm{m}^{3} \\
2019\end{array}$ & 47,8 & 41,0 & 35,0 & 29,2 & 27,3 & 26,1 & 31,1 \\
\hline $\begin{array}{l}\text { Annual mean in } \mu \mathrm{g} / \mathrm{m}^{3} \\
2020\end{array}$ & 35,2 & 32,0 & 28,6 & 23,5 & 22,3 & 18,4 & 23,4 \\
\hline DIFF & $-26 \%$ & $-22 \%$ & $-18 \%$ & $-19 \%$ & $-18 \%$ & $-29 \%$ & $-25 \%$ \\
\hline $\begin{array}{l}\text { Highest one day mean in } \\
\mu \mathrm{g} / \mathrm{m}^{3} 2019\end{array}$ & 98,4 & 56,7 & 92,5 & 80,2 & 79,9 & 70,6 & 73,2 \\
\hline $\begin{array}{l}\text { Highest one day mean in } \\
\mu \mathrm{g} / \mathrm{m}^{3} 2020\end{array}$ & 83,7 & 70,2 & 69,1 & 63,6 & 65,3 & 69,0 & 67,0 \\
\hline DIFF & $-15 \%$ & $24 \%$ & $-25 \%$ & $-21 \%$ & $-18 \%$ & $-2 \%$ & $-8 \%$ \\
\hline $\begin{array}{l}\text { No. hours NO2 > } 200 \text { in } \\
\mu \mathrm{g} / \mathrm{m}^{3} 2019\end{array}$ & 2 & 2 & 0 & 0 & 0 & 0 & 1 \\
\hline $\begin{array}{l}\text { No. hours NO2 > } 200 \text { in } \\
\mu \mathrm{g} / \mathrm{m}^{3} 2020\end{array}$ & 0 & 0 & 0 & 0 & 0 & 0 & 0 \\
\hline $\begin{array}{l}\text { Highest measured value } \\
\text { in } \mu \mathrm{g} / \mathrm{m}^{3} 2019 \text { (across all } \\
\text { stations) }\end{array}$ & - & 233 & - & - & - & - & - \\
\hline $\begin{array}{l}\text { Highest measured value } \\
\text { in } \mu \mathrm{g} / \mathrm{m}^{3} \quad 2020 \text { (across all } \\
\text { stations) }\end{array}$ & - & - & - & - & - & - & 145 \\
\hline
\end{tabular}

Source: Own illustration based on data provided by the City Council of Barcelona (Ajuntament de Barcelona, 2020c).

Note: 1) Green shaded cells imply compliance with WHO and EU limits. Yellow shaded cells mean that values are compliant with EU limits, but not with WHO guidelines and cells in red imply that values are neither compliant with EU nor with WHO limits. 2) The last two rows only display the highest valued measured throughout the year at any station. Hence, only one cell per row shows a value.

The reduction in air pollution in the year 2020 demonstrates the close link between air quality and mobility patterns. Adrià Gomila, Director of Mobility in the City Council of Barcelona commented the following in this regard:

"The pandemic has shown us (Barcelona's citizens) in a life experiment how mobility is related to air quality. This situation (with almost no mobility) is clearly not what we want. However, I believe it has opened our eyes to possibilities how to avoid unnecessary mobility, e.g. through working remotely, tele-medicine or online education. I think that is something we can build on." (A. Gomila, personal communication, 14.01.2021).

Although it might seem obvious that the reduction in air pollution is due to the reduction in mobility, there might well be other contributing factors. The Government of Catalonia has analysed air quality changes in the Region from the beginning of the pandemic to August 2020. The analysis underlines 
that, apart from an extraordinary reduction in road traffic, meteorological conditions have probably contributed to the decrease in air pollution. It has been a warm period with a lot of meteorological variability, which has favoured the dispersion and cleaning of air pollutants (Generalitat de Cataluña, 2020a).

\section{Changes in GHG emissions}

This section provides an estimate of GHG emission reduction due to the reduced mobility in Barcelona in the year 2020.

With its massive reduction in mobility the pandemic has had a significant impact on Barcelona's GHG emissions in 2020. The City Council of Barcelona estimates that emissions from road traffic have decreased by more than 140,000 t CO2eq during the lockdown (from March $16^{\text {th }}$ to June $21^{\text {st }}$ ) which corresponds to $14 \%$ of annual GHG emissions from transport and $4 \%$ of the City's overall GHG emissions (Ajuntament de Barcelona, 2020d). For the entire year, the City Council has not yet published the GHG emissions. Yet, with an average traffic reduction of $28 \%$ in 2020 compared to prepandemic levels, one can estimate the GHG emission reduction for Barcelona's transport sector at 247.779 t CO2eq, which corresponds to $25 \%$ of transport emissions and $7 \%$ of the City's overall emissions in a year (see Table 7 below). 
Universidad de Barcelona

Behavioural changes in urban mobility in Barcelona due to the COVID-19 pandemic and its impact on air pollution and greenhouse gas emissions

Corinna Peters

Table 7: Estimation of GHG emissions reduction in transport in 2020.

\begin{tabular}{|c|c|c|c|c|c|}
\hline & Value & $\begin{array}{c}\text { Percent of } \\
\text { annual } \\
\text { transport } \\
\text { emissions }\end{array}$ & $\begin{array}{c}\text { Percent } \\
\text { of annual } \\
\text { GHG } \\
\text { emission }\end{array}$ & Source & Comment \\
\hline $\begin{array}{l}\text { Overall transport } \\
\text { emissions (in t CO2 eq) }\end{array}$ & 1.008 .000 & $100 \%$ & $28 \%$ & $\begin{array}{l}\text { Barcelona's } \\
\text { Energy Agency }\end{array}$ & Latest available data is from 2018 \\
\hline $\begin{array}{l}\text { Emissions road traffic (in } \mathrm{t} \\
\mathrm{CO} 2 \mathrm{eq} \text { ) }\end{array}$ & 896.532 & $89 \%$ & $25 \%$ & $\begin{array}{l}\text { City Council of } \\
\text { Barcelona }\end{array}$ & $\begin{array}{l}\text { Based on traffic emissions of a } \\
\text { standard week }(17,241 \text { t CO2eq) }\end{array}$ \\
\hline $\begin{array}{l}\text { Reduction in road traffic } \\
\text { in } 2020 \text { (in \%) }\end{array}$ & $-28 \%$ & na & na & $\begin{array}{l}\text { City Council of } \\
\text { Barcelona }\end{array}$ & $\begin{array}{c}\text { Average of daily reductions; } \\
\text { deducted by comparing traffic } \\
\text { intensity of that day to February } \\
\text { levels; due to lack of data all days } \\
\text { before March } 2 \text { nd are assumed to } \\
\text { be at the same traffic intensity } \\
\text { level as February }\end{array}$ \\
\hline $\begin{array}{l}\text { Reduction in GHG } \\
\text { emissions from road } \\
\text { traffic during lockdown } \\
\text { (in t } \mathrm{CO} 2 \text { eq) }\end{array}$ & -141.268 & $-14 \%$ & $-4 \%$ & $\begin{array}{l}\text { City Council of } \\
\text { Barcelona }\end{array}$ & $\begin{array}{l}\text { Estimated for period from March } \\
\text { 16th to 21st June } 2020\end{array}$ \\
\hline $\begin{array}{l}\text { Reduction in GHG } \\
\text { emissions from road } \\
\text { traffic (in t } \mathrm{CO} 2 \text { eq) }\end{array}$ & -247.779 & $-25 \%$ & $-7 \%$ & $\begin{array}{l}\text { Own } \\
\text { estimation }\end{array}$ & $\begin{array}{c}\text { Calculated by multiplying } \\
\text { 'Emissions road traffic' with } \\
\text { 'Reduction in road traffic in } 2020 \text { '; } \\
\text { same logic as applied by the City } \\
\text { Council to estimate emission } \\
\text { reduction }\end{array}$ \\
\hline
\end{tabular}

Source: Own illustration based on data from the City Council of Barcelona (Agència d'Energia de Barcelona, 2020; Ajuntament de Barcelona, 2020d).

Note: Overall, emissions from railways play a minor role due to Catalonia's low grid emission factor (Agència d'Energia de Barcelona, 2020). Also, Barcelona's Transport Organisation (TMB), which is responsible for Barcelona's metro, buys all its electricity from renewable energy sources (Transports Metropolitans de Barcelona, 2020). Data on emissions from other types of railway services were not available.

It remains unclear how mobility induced GHG emissions will develop in the coming months and once the pandemic is over. If the trend of more individual motorized transport persists, the pandemic could also lead to increased GHG emissions in the long run (Bucsky, 2020).

\section{Conclusion and implications}

This final section summarises the main findings of the case study, presents policy implications based on the findings and a brief outlook.

\section{Changes in mobility (specific objective (i))}

Barcelona - like many cities across the globe - has experienced an unprecedented reduction in mobility due to mobility restrictions and behavioural changes to contain the COVID-19 pandemic, accounting for an about $90 \%$ drop during the strict lockdown (March to June). Even after this phase, mobility remains at a lower level compared to before the pandemic. Barcelona's citizens seem to 
Behavioural changes in urban mobility in Barcelona due to the COVID-19 pandemic and its impact on air pollution and greenhouse gas emissions

Corinna Peters

have reduced their mobility mostly to avoid the risk infecting themselves with the virus and because they 'work/study (more) from home' (according to the results of the online survey).

Most remarkable is the reduction in use of public transport, which before the pandemic has been a very popular mode of transport among Barcelona's citizens. At the same time use of individual motorized transport has recovered to almost pre-pandemic levels in the summer of 2020 and early autumn. This change away from public transport towards individual (motorized) transport is worrisome for environmental and financial reasons. Public transport service providers across the globe struggle with financial viability, and the radical loss of demand during the pandemic has exacerbated the problem (Tirachini \& Cats, 2020). Barcelona is no exception with losses occurring during the pandemic adding to the deficit of the public transport system (ElEconomista, 2020; Ajuntament de Barcelona, 2021a). The shift in modal split towards usage of cars and motorcycles could counteract efforts in recent years towards low emission mobility.

Another striking change in mobility behaviour during the pandemic is the surge in cycling, especially on weekends with traffic intensity up to $60 \%$ higher than on weekends before the pandemic. The results of the online survey indicate that the increase in cycling has been particularly pronounced in the age group of 36-to-45-year-olds. Further research would be required to confirm and explain this observation. Overall, cycling still plays a minor role in Barcelona as a means of transport (2,3\% modal share) despite the City's good climatic and geographic conditions. The low modal share, the high increase in cycling on weekends during the pandemic and low bicycle ownership, especially among the low-income group (of the survey), could indicate that it is still considered mainly a leisure activity instead of a cost-effective means of transport. Further research is required to confirm this finding.

\section{Change in air quality (specific objective (ii))}

These changes in mobility have led to a reduction in air pollution in Barcelona. Especially during the strict lockdown from March to June concentration of most air pollutants has dropped to very low levels (Generalitat de Cataluña, 2020a). The annual mean concentrations of two of the most problematic pollutants, NO2 and PM10, have reached historical lows in 2020. PM10 concentrations were at $19,2 \mu \mathrm{g} / \mathrm{m}^{3}$ (-20\% compared to 2019$)$ complying with the WHO guideline $\left(20 \mathrm{\mu g} / \mathrm{m}^{3}\right)$ for the first time in over 20 years (Agència De Salut Pública Barcelona, 2020; Ajuntament de Barcelona, 2020c). NO2 annual mean was $23,9 \mu \mathrm{g} / \mathrm{m}^{3}$ thereby $28 \%$ lower than last year's annual mean and complying with WHO and EU limits $\left(40 \mathrm{\mu g} / \mathrm{m}^{3}\right)$. In 2020 even the two high transit areas Eixample and Gràcia complied with WHO/EU limits (Ajuntament de Barcelona, 2020c). The reduction in air pollution in the year 2020 demonstrates the close link between air quality and mobility patterns.

Change in GHG emissions (specific objective (iii))

With its massive reduction in mobility, the pandemic has also had a significant impact on Barcelona's GHG emissions in 2020. With an average traffic reduction of $28 \%$ in 2020 compared to pre-pandemic levels, one can estimate the GHG emission reduction for Barcelona's transport sector at 247.779 t CO2eq, which corresponds to $25 \%$ of transport emissions and $7 \%$ of the City's overall emissions in a year. 
Universidad de Barcelona

Behavioural changes in urban mobility in Barcelona due to the COVID-19 pandemic and its impact on air pollution and greenhouse gas emissions

Corinna Peters

\section{Citizens' preferences (specific objective (iv))}

'Getting fast to one's destination' was the most important factor for choosing a mode of transport among survey respondents, followed by convenience, affordability, and reliability. Considering these top four reasons, it seems surprising that cycling has such a low modal share in Barcelona. Cycling can be in many cases the fastest mode of transport depending on the distance and traffic situation (Dobrzanski et al., 2020). It is apart from walking by far the cheapest mode of transport ${ }^{17}$ and a very reliable one, as it is independent from congestions. It also is convenient in terms of bringing you from door to door, but might be perceived by some commuters as inconvenient as it requires physical activity. Travelling environmentally friendly was given relatively low importance for choosing a mode of transport, although the majority of respondents reported to support climate-friendly mobility policies, like extending pedestrian areas and the cycling network, while reducing car space. Given the small number of survey participants, the results could be strengthened with further research on citizens' preferences regarding urban mobility policy.

The results of the survey indicate that people do not cycle (more) because they do not have a bicycle or/and no subscription to the bike sharing service 'Bicing'. 'Feeling unsafe cycling next to cars' was reported to be another relevant factor for not choosing the bicycle as a means of transport among respondents of the survey as was 'having things to carry'.

Policy implications (specific objective (v))

In the context of the 2015 United Nations Climate Change Conference in Paris, Barcelona has committed to reducing its GHG emissions per capita by $40 \%$ by 2030 compared to 2005 levels (Ajuntament de Barcelona, 2018). One of the City's lines of action is improving urban mobility with a combination of measures to reduce mobility, distribute it more evenly over the day, and to promote less-polluting ways of mobility, e.g. individual motorized transport shall be reduced by $20 \%$. Measures presented include extending the cycling network, creating more superblocks, and promoting the development of business mobility plans.

Public transport plays a crucial role in implementing Barcelona's Climate Plan (Ajuntament de Barcelona, 2018). It is difficult to imagine effective, climate-friendly urban mobility without a good public transport system in place, as Adrià Gomila, Head of Mobility at the City Council of Barcelona, pointed out:

"I do not see how mobility in a major city like Barcelona can function without public transport. There is no other means of transport that can provide mobility at such high capacity, at medium and long distances while being climate-friendly." (A. Gomila, personal communication, 14.1.2021).

One of the main challenges for ATM and Barcelona is to recover lost demand in public transport and "regain citizens" trust" in public transport as Xavier Sanyer, Head of Mobility Services of ATM,

\footnotetext{
${ }^{17}$ Annual costs would be 50 EUR for paying the annual fee for the bike sharing service 'Bicing' or could be estimated to 93 EUR for your own bicycle (assuming the cost for a second-hand bike of 100 EUR, which lasts for 3 years (i.e. 33 EUR per year) and repair costs of 60 EUR a year).
} 
Behavioural changes in urban mobility in Barcelona due to the COVID-19 pandemic and its impact on air pollution and greenhouse gas emissions

underlined (X. Sanyer, personal communication, 18.1.2021). In order to do that Lluis Alegre, Director of Mobility at ATM, explained:

"We have taken measures to keep people safe and regain their trust in public transport. For example, we are providing hand sanitizer at every metro station, we have doubled the ventilation capacity of the metro and we keep people informed about the occupancy rates. We believe that if we do things well and communicate them better, we can regain people's trust." (L. Alegre, personal communication, 18.1.2021).

Apart from regaining citizens' confidence that travelling with public transport is safe in the current situation, Barcelona could examine new ways of making public transport attractive again, such as limiting road traffic and parking spaces, introducing access charges, and reducing the cost of public transport (Bucsky, 2020).

During the last years and in particular during the pandemic the City Council of Barcelona has taken measures to reduce car space and extend pedestrian areas and the cycling network. Those are changes that will last beyond the duration of the pandemic, as confirmed by Adrià Gomila, Head of Mobility at the City Council of Barcelona:

"One of the questions people always ask me is, whether the measures implemented during the pandemic (like the extension of bike lanes) will stay permanently, and my answer is a definite 'Yes!' for the majority of the measures. There are a few extensions of pedestrian areas, that are only provisional, but the rest of the changes are here to stay." (A. Gomila, personal communication, 14.1.2021).

However, to establish a "cycling culture" where the bicycle is seen as a main mode of transport and to reach modal shares as high as in cycling-friendly cities like Copenhagen (modal share of 28\%) there is still a long way to go for Barcelona. To change the perception of cycling and convince people to choose the bicycle more often over other modes of transport, the City could implement a number of measures, such as awareness campaigns to inform Barcelona's citizens that cycling is indeed one of the cheapest and fastest modes of transport. Also, one could consider measures that make cycling within the City (even) faster than motorized transport, e.g. by reducing car space, reducing speed limits within the city, and setting the timing of traffic lights to cycling speed - at least on a select number of particularly 'bike-friendly roads'. To overcome the problem of people not owning a bike, one could offer the bike sharing service 'Bicing' (or a similar service) for free for a limited amount of time as has been already implemented in New York City (Pase et al., 2020). To ensure that the bikes are returned, the use of the service could require a credit card to access a bike but that is not charged (rather only if a bike is not returned within a pre-established number of hours). This latter option could be implemented, such as the next few years, until an established objective of greater behavioural change and bike use is achieved in the city (e.g. reaching $15 \%$ modal share for cycling). Also, the City could provide the bike sharing service without any subscription process as is already being implemented in other cities like London (Transport for London, 2021) - as subscription is known to deter citizens (as well as all tourists) given the initial administrative burden and the annual fee. To increase safety of cyclists, the cycling network could be extended and/or modified (e.g. separate the bike lanes from the lane for motorized transport, e.g. with small trees, bushes or plants 
Behavioural changes in urban mobility in Barcelona due to the COVID-19 pandemic and its impact on air pollution and greenhouse gas emissions

Corinna Peters

between the car and bike lanes as in cities such as Berlin). Extending the cycling network has been shown to positively influence the modal share of cycling in a study in 112 European cities (Santos et al., 2013). In addition, the City Council could investigate whether it would be worthwhile expanding 'Bicing' by offering some transport bikes among its inventory. Such analysis could shed light on the potential demand in different parts of the city at different prices and what kind of objects people need to transport.

\section{Outlook}

Further research would be needed to confirm the findings of this study and help explain commuters' choices and preferences. As this study's survey was limited to 100 participants, it is suggested to conduct a larger survey addressing the same questions. Also, additional research will be needed in the future to estimate longer term implications of the pandemic for mobility behaviour and emissions.

One of the core challenges for urban planners, and in particular for planners in public transport, is to estimate how urban mobility will develop in the coming months and years (Ajuntament de Barcelona, 2021b). Although the majority of respondents of this study's survey reported that they intend to return to their pre-pandemic transport behaviour once the pandemic is over, it is possible that greater use of home office and online shopping imply less mobility in the long term. This could lead to reduced congestions in cities, which can make road transport more favourable for commuters and counteract efforts to increase the modal share of climate-friendly transport (Bucsky, 2020). On the other hand, reduced mobility could be used to reduce car space in favour of bus lanes, pedestrian areas or cycling network, as has been already implemented by the City Council of Barcelona in late 2020.

Concerning the City's mobility planning for a time after the pandemic Adrià Gomila, Head of Mobility at the City Council of Barcelona, commented:

"One of the main challenges after the pandemic (when people return to their offices) will be how to ensure effective mobility in the city, while exploring ways to avoid unnecessary mobility." (A. Gomila, personal communication, 14.1.2021).

It is currently impossible to predict how long the fear of contagion will reduce demand for public transport and impact overall modal split (Bucsky, 2020). It therefore remains unclear how mobility induced air pollution and GHG emissions will develop in the coming months and once the pandemic is over. If the trend of more individual motorized transport would persist, the pandemic could possibly have an overall negative impact, if no countermeasures are implemented. However, the momentum of the major changes in mobility could also be used as an opportunity for reform by implementing the needed changes in infrastructure and fostering the needed behavioural changes to ensure that Barcelona's urban mobility reduces its emissions and that the City meets its climate target for 2030. 
Behavioural changes in urban mobility in Barcelona due to the COVID-19 pandemic and its impact on air pollution and greenhouse gas emissions

\section{References}

ACN. (2020a, April 25). Torra to request to Spain to return Catalan authority in coronavirus management. CatalanNews.

ACN. (2020b, April 28). Spain's president unveils four-phase plan to ease lockdown aiming for "new normality" at end of June. CatalanNews.

ACN. (2020c, May 4). Face masks distributed as they become obligatory on public transport. CatalanNews.

ACN. (2020d, May 22). Barcelona area to enter Phase 1 of lockdown de-escalation on Monday. CatalanNews.

ACN. (2020e, June 18). Lockdown eased throughout much of Catalonia. CatalanNews.

Agència d'Energia de Barcelona. (2020). Balanc d'energia $i$ emissions de Gasos amb effecte d'hivernacle de Barcelona - 2018.

Agència De Salut Pública Barcelona. (2020). Qualitat de l'aire. Informe 2019.

Agencia Estatal de Meteorología (AEMET). (2020). Valores climatológicos normales. http://www.aemet.es/es/serviciosclimaticos/datosclimatologicos/valoresclimatologicos?k=cat

Ajuntament de Barcelona. (n.d.). Economia, Treball, Competitivitat i Hisenda - Turisme. Retrieved February 10, 2021, from https://ajuntament.barcelona.cat/economiatreball/ca/turisme

Ajuntament de Barcelona. (2016). Programa de mesures contra la contaminació de l'aire.

Ajuntament de Barcelona. (2018). Plan Clima 2018-2030.

Ajuntament de Barcelona. (2019). Població resident. 2000-2019. https://www.bcn.cat/estadistica/catala/dades/inf/lecpadro/lec19/t61.htm

Ajuntament de Barcelona. (2020a). Anuari Estadístic de la Ciutat de Barcelona.

Ajuntament de Barcelona. (2020b). By motorcycle. https://www.barcelona.cat/mobilitat/en/meansof-transport/motorcycle

Ajuntament de Barcelona. (2020c). Datos de las estaciones de medida de la calidad del aire de la ciudad de Barcelona. Open Data BCN. https://opendataajuntament.barcelona.cat/data/es/dataset/qualitat-aire-detall-ben

Ajuntament de Barcelona. (2020d). Declaració d'emergència climàtica - informe de seguiment de l'emergència climàtica.

Ajuntament de Barcelona. (2020e). El Pla de Mobilitat Urbana 2024 concreta un total de 60 línies d'actuació i més de 300 mesures per assolir una mobilitat més sostenible, segura i saludable. https://ajuntament.barcelona.cat/premsa/2020/12/01/el-pla-de-mobilitat-urbana-2024concreta-un-total-de-60-linies-dactuacio-i-mes-de-300-mesures-per-assolir-una-mobilitat-messostenible-segura-i-saludable/

Ajuntament de Barcelona. (2020f). Estadística i Difusió de Dades - Barcelona's annual Gross Domestic $\begin{array}{llll}\text { Product } & \text { (GDP). } & \text { Statistical } & \text { review }\end{array}$ https://www.bcn.cat/estadistica/angles/dades/economia/pib/pib_anual/T2.htm

Ajuntament de Barcelona. (2020g). Measures to combat Covid-19 in Barcelona. 
Universidad de Barcelona

Behavioural changes in urban mobility in Barcelona due to the COVID-19 pandemic and its impact on air pollution and greenhouse gas emissions

Corinna Peters

https://www.barcelona.cat/covid19/ca/mesures-barcelona-contra-la-covid-19

Ajuntament de Barcelona. (2020h). Pla de Mobilita Urbana 2024 (Sept 2020).

Ajuntament de Barcelona. (2020i). Seguiment COVID-19 a Barcelona - Mobilitat i transports. https://dades.ajuntament.barcelona.cat/seguiment-covid19-bcn/

Ajuntament de Barcelona. (2020j). Turistes $i$ pernoctacions als hotels de Barcelona. https://ajuntament.barcelona.cat/barcelonaeconomia/ca/turisme-fires-i-congressos/activitatturistica/turistes-i-pernoctacions-als-hotels-de-barcelona

Ajuntament de Barcelona. (2021a). Barcelona Economia - Transport públic collectiu a la regió metropolitana. https://ajuntament.barcelona.cat/barcelonaeconomia/ca/transports-icomunicacions/transport-public-collectiu-la-regio-metropolitana

Ajuntament de Barcelona. (2021b). Barcelona Economia - Transport públic urbà i rodalia. https://ajuntament.barcelona.cat/barcelonaeconomia/ca/transports-icomunicacions/transport-public-collectiu-la-regio-metropolitana/transport-public-urba-i

Ajuntament de Barcelona. (2021c). Barcelona en el context econòmic espanyol i mundial.

Ajuntament de Barcelona. (2021d). Dades públiques Mobilitat. https://drive.google.com/drive/folders/1Moq8gDiWa34ek61QV-A7MinubG93UYs7

Ajuntament de Barcelona. (2021e). Estaciones de medida de la calidad del aire de la ciudad de Barcelona. Open Data BCN. https://opendataajuntament.barcelona.cat/data/es/dataset/qualitat-aire-estacions-bcn

Ajuntament de Barcelona. (2021f). Seguiment COVID-19 a Barcelona - Evolució diària. https://dades.ajuntament.barcelona.cat/seguiment-covid19-bcn/

Almeida, F., Superior, I., Gaya, P., Queirós, A., \& Faria, D. (2017). Strengths and Limitations of Qualitative and Quantitative Research Methods. European Journal of Education Studies, 3(9), 369-387. https://doi.org/10.5281/zenodo.887089

Àrea Metropolitana de Barcelona. (2020a). Geoportal de Cartografia. https://geoportalcartografia.amb.cat/AppGeoportalCartografia2/?locale=ca\&Categoria=Cartogr afia\&Producte $=1 \#$

Àrea Metropolitana de Barcelona. (2020b). Municipios metropolitanos. https://www.amb.cat/s/es/web/area-metropolitana/municipis-metropolitans.html

Autoritat del Transport Metropolità. (2019). Emef 19 - Enquesta de Mobilitat en Feiner.

Autoritat del Transport Metropolità. (2020). Enquesta de Mobilitat en Dia Feiner 2019.

Autoritat del Transport Metropolità de Barcelona. (2020). El Pla Director de Mobilitat del Sistema Metropolitana de Barcelona 2020-2025.

Autoritat del Transport Metropolità de Barcelona. (2021). Evolució de la mobilitat a l'àmbit de l'ATM Barcelona.

https://datastudio.google.com/reporting/8134194c-db6d-4d6a-ac8bfd5e34dbfc4d/page/oWSOB

Ayuntamiento de Madrid. (2020). Estadística - Datos geográficos y administrativos. https://www.madrid.es/portales/munimadrid/es/Inicio/El-Ayuntamiento/Estadistica/Areas-deinformacion-estadistica/Territorio-climatologia-y-medio-ambiente/Territorio/Datosgeograficos-yadministrativos/?vgnextoid=2bfd2e44a3f59210VgnVCM2000000c205a0aRCRD\&vg 
Universidad de Barcelona

Behavioural changes in urban mobility in Barcelona due to the COVID-19 pandemic and its impact on air pollution and greenhouse gas emissions

Corinna Peters

Baldasano, J. M. (2020). COVID-19 lockdown effects on air quality by NO2 in the cities of Barcelona and Madrid (Spain). Science of the Total Environment, 741(2). https://doi.org/10.1016/j.scitotenv.2020.140353

Barbieri, D. M., Lou, B., Passavanti, M., Hui, C., Lessa, D. A., Maharaj, B., Banerjee, A., Wang, F., Chang, K., Naik, B., Yu, L., Liu, Z., Sikka, G., Tucker, A., Foroutan Mirhosseini, A., Naseri, S., Qiao, Y., Gupta, A., Abbas, M., ... Adomako, S. (2020). A survey dataset to evaluate the changes in mobility and transportation due to COVID-19 travel restrictions in Australia, Brazil, China, Ghana, India, Iran, Italy, Norway, South Africa, United States. Data in Brief, 33, 106459. https://doi.org/10.1016/j.dib.2020.106459

Bednar-Friedl, B., Wolkinger, B., König, M., Bachner, G., Formayer, H., Offenthaler, I., \& Leitner, M. (2015). Transport. In Climate Change 2014: Mitigation of Climate Change. Contribution of Working Group III to the Fifth Assessment Report of the Intergovernmental Panel on Climate Change (pp. 279-300). https://doi.org/10.1007/978-3-319-12457-5_15

Benito, E. DE, \& Cuè, C. E. (2020). Madrid region and Barcelona to remain in Phase 0, but with some coronavirus restrictions eased. EL PAIS.

Borkowski, P., Jażdżewska-Gutta, M., \& Szmelter-Jarosz, A. (2021). Lockdowned: Everyday mobility changes in response to COVID-19. Journal of Transport Geography, 90(November 2020). https://doi.org/10.1016/j.jtrangeo.2020.102906

Bucsky, P. (2020). Modal share changes due to COVID-19: The case of Budapest. Transportation Research Interdisciplinary Perspectives, 8. https://doi.org/10.1016/j.trip.2020.100141

C40 Cities Climate Leadership Group. (2020). Greenhouse gas emissions interactive dashboard. https://www.c40knowledgehub.org/s/article/C40-cities-greenhouse-gas-emissions-interactivedashboard?language=en_US

Catà Figuls, J. (2020, August 25). Las escuelas de Cataluña abrirán el 14 de septiembre con grupos estancos y entradas y salidas escalonadas. El País.

Cercós, L. (2020, October 25). Toque de queda en Catalunya: estos son los horarios y todas las excepciones. El Nacional.

Chan, H. F., Skali, A., Savage, D. A., Stadelmann, D., \& Torgler, B. (2020). Risk attitudes and human mobility during the COVID-19 pandemic. Scientific Reports, 10(1). https://doi.org/10.1038/s41598-020-76763-2

City of Copenhagen. (2018). The Bicycle Account 2018 - Copenhagen City of Cyclists.

DMQ - eldesmarque. (2020, April 13). ¿Qué actividades no esenciales vuelven al trabajo el lunes 13 de abril?

Dobrzanski, P., Smieszek, M., \& Dobranska, M. (2020). Bicycle Transport Within Selected Polish and European Union cities. Humanities and Social Sciences, 27(2), 55-66.

El Pais. (2020). Spanish government announces areas that will move to the next phase of coronavirus deescalation.

El Periodico. (2020). Corredores y ciclistas toman Barcelona en el primer día de permiso. https://www.elperiodico.com/es/sociedad/20200502/corredores-yciclistas-toman-las-callesen-el-primer-dia-de-permiso-7947763

ElEconomista. (2020, December 17). La ATM cifra en 750 millones el déficit en el sistema de transporte público metropolitano. 
Universidad de Barcelona

Behavioural changes in urban mobility in Barcelona due to the COVID-19 pandemic and its impact on air pollution and greenhouse gas emissions

Corinna Peters

EPOMM. (2020). TEMS - THE EPOMM MODAL SPLIT TOOL. http://tems.epomm.eu/search_city.phtml

Esteban, P., \& Romero, J. (2020). Toda España arranca la desescalada el lunes con Madrid, Barcelona y toda CyL en fase 1. El Confidencial.

EURACTIV. (2020, July 22). New COVID-19 spike forces Barcelona to go back into lockdown.

European Comission. (2016). The State of European Cities 2016.

European Comission. (2020). Cities (Urban audit). https://ec.europa.eu/eurostat/web/cities/data/database

Directive 2008/50/EC, (2008).

Evans, J. R., \& Mathur, A. (2005). The value of online surveys. Internet Research, 15(2), 195-219. https://doi.org/10.1108/10662240510590360

Generalitat de Cataluna. (2014). Climatologia. El Barcelonès. 1961 -1990.

Generalitat de Cataluña. (2020a). Avaluació de l' impacte de la COVID-19 sobre la qualitat de I' aire a Catalunya.

Generalitat de Cataluña. (2020b). Mesures per a la contenció de la COVID-19 aplicables a partir del 21 de desembre a Catalunya. https://canalsalut.gencat.cat/ca/salut-a-z/c/coronavirus-2019ncov/ciutadania/mesures-contencio-COVID-19-aplicables-partir-7-gener-catalunya/mesurescontencio-covid-aplicables-21-desembre/

Generalitat de Cataluña. (2020c). RESOLUCIÓN SLT/2546/2020. In Diari Oficial de la Generalitat de Catalunya (Issue 8248, pp. 1-10). Generalitat de Cataluna.

Gilibert, M., Ribas, I., \& Rodriguez-Donaire, S. (2017). Analysis of Mobility Patterns and Intended Use of Shared Mobility Services in Barcelona Region.

Gobierno de España. (2020). Real Decreto 463/2020. In Boletín Oficial del Estado (Vol. 67, pp. 2539025400).

Google. (2021). COVID-19 Community Mobility Reports. https://www.google.com/covid19/mobility/index.html?hl=en

Güell, O. (2020, October 15). What is behind the spike in coronavirus cases in Catalonia? El País.

Hebel, K., \& Wolek, M. (2017). Change Trends in the Use of Passenger Cars on Urban Trips: CarPooling in Gdynia. Scientific Journal of Silesian University of Technology. Series Transport, 96, 37-47. https://doi.org/10.20858/sjsutst.2017.96.4

Henríquez, J., Gonzalo-Almorox, E., García-Goñi, M., \& Paolucci, F. (2020). The first months of the COVID-19 pandemic in Spain. Health Policy and Technology, 9(4), 560-574. https://doi.org/10.1016/j.hlpt.2020.08.013

IEA. (2020a). Changes in transport behaviour during the Covid-19 crisis.

IEA. (2020b). The Covid-19 Crisis and Clean Energy Progress.

Institute for Transportation \& Development Policy. (2020). Pedestrians First - View City Measures. https://pedestriansfirst.itdp.org/city-tool/

Intergovernmental Panel on Climate Change. (2015). Human Settlements, Infrastructure, and Spatial Planning. Climate Change 2014 Mitigation of Climate Change, 923-1000. https://doi.org/10.1017/cbo9781107415416.018 
Universidad de Barcelona

Behavioural changes in urban mobility in Barcelona due to the COVID-19 pandemic and its impact on air pollution and greenhouse gas emissions

Corinna Peters

La Vanguardia. (2020a, April 12). ¿Quién puede regresar a trabajar este lunes 13 de abril?

La Vanguardia. (2020b, May 2). Los más deportistas madrugan en el primer día en la calle desde el confinamiento.

La Vanguardia. (2020c, May 16). ¿Qué es la fase 0,5 y qué avances permite?

Levay, K. E., Freese, J., \& Druckman, J. N. (2016). The Demographic and Political Composition of Mechanical Turk Samples. SAGE Open, 6(1). https://doi.org/10.1177/2158244016636433

López, C. (2020, April 28). La desescalada tendrá 4 fases, durará al menos 8 semanas y se aplicará por provincias. La Vanguardia.

Madrid Destino. (2020). Tourism Report.

Marquet, O., \& Miralles-Guasch, C. (2016). City of Motorcycles. On how objective and subjective factors are behind the rise of two-wheeled mobility in Barcelona. Transport Policy, 52, 37-45. https://doi.org/10.1016/j.tranpol.2016.07.002

Meena, S. (2020). Impact of novel Coronavirus (COVID-19) pandemic on travel pattern: A case study of India. Indian Journal of Science and Technology, 13(24), 2491-2501. https://doi.org/10.17485/ijst/v13i24.958

Ministerio de Sanidad. (2020). Plan para la transición hacía una Nueva Normalidad: Guía De La Fase 2 (p. 24).

Ministerio de Sanidad de España. (2020a). Anexo II. - PREVISIÓN ORIENTATIVA PARA EL LEVANTAMIENTO DE LAS LIMITACIONES DE ÁMBITO NACIONAL ESTABLECIDAS EN EL ESTADO DE ALARMA, EN FUNCIÓN DE LAS FASES DE TRANSICIÓN A UNA NUEVA NORMALIDAD.

Ministerio de Sanidad de España. (2020b). Orden SND/388/2020. In Boletín Oficial del Estado (pp. 18).

Ministerio de Sanidad de España. (2020c). Orden SND/399/2020. In Boletín Oficial del Estado (Vol. 130, Issue 9 mayo 2020, pp. 31998-32026).

Ministerio de Sanidad de España. (2020d). Plan para la transisción hacia una nueva normalidad. (Vol. 53, Issue 9, pp. 1689-1699).

Morey, L. C., \& McCredie, M. N. (2019). Who Are the Turkers? A Characterization of MTurk Workers Using the Personality Assessment Inventory. Assessment, 26(5), 759-766.

Moslem, S., Campisi, T., Szmelter-Jarosz, A., Duleba, S., Nahiduzzaman, K. M., \& Tesoriere, G. (2020). Best-worst method for modelling mobility choice after COVID-19: Evidence from Italy. Sustainability (Switzerland), 12(17), 1-19. https://doi.org/10.3390/SU12176824

Mouzo, J. (2020, October 21). Los nuevos casos de covid-19 en Cataluña se duplican en dos semanas. EL PAIS.

Mueller, N., Rojas-rueda, D., Khreis, H., Cirach, M., Andrés, D., Ballester, J., Bartoll, X., Daher, C., Deluca, A., Echave, C., Milà, C., Márquez, S., Palou, J., \& Pérez, K. (2020). Changing the urban design of cities for health: The superblock model. Environment International, 134(September 2019), 105132. https://doi.org/10.1016/j.envint.2019.105132

Nayak, M. S. D. P., \& Narayan, K. A. (2019). Strengths and Weakness of Online Surveys. IOSR Journal of Humanities And Social Science, 24(5), 31-38. https://doi.org/10.9790/0837-2405053138

Parady, G., Taniguchi, A., \& Takami, K. (2020). Travel behavior changes during the COVID-19 
Behavioural changes in urban mobility in Barcelona due to the COVID-19 pandemic and its impact on air pollution and greenhouse gas emissions

pandemic in Japan: Analyzing the effects of risk perception and social influence on going-out self-restriction. Transportation Research Interdisciplinary Perspectives, 7, 100181. https://doi.org/10.1016/j.trip.2020.100181

Parvez, M., Hazelton, J., \& James, G. (2019). Greenhouse gas emissions disclosure by cities: the expectation gap. Sustainability Accounting, Management and Policy Journal, 10(4), 685-709. https://doi.org/10.1108/SAMPJ-11-2017-0138

Pase, F., Chiariotti, F., Zanella, A., \& Zorzi, M. (2020). Bike Sharing and Urban Mobility in a PostPandemic World. IEEE Access, 8, 187291-187306. https://doi.org/10.1109/access.2020.3030841

Pawar, D. S., Yadav, A. K., Akolekar, N., \& Velaga, N. R. (2020). Impact of physical distancing due to novel coronavirus (SARS-CoV-2) on daily travel for work during transition to lockdown. Transportation Research Interdisciplinary Perspectives, 7, 100203. https://doi.org/10.1016/j.trip.2020.100203

Pepe, E., Bajardi, P., Gauvin, L., Privitera, F., Lake, B., Cattuto, C., \& Tizzoni, M. (2020). COVID-19 outbreak response, a dataset to assess mobility changes in Italy following national lockdown. Scientific Data, 7(1), 3-9. https://doi.org/10.1038/s41597-020-00575-2

Pérez Díez, F., Cabrerizo Sinca, J., \& Campos Cacheda, J. M. (2018). Evolution, the current state and recent trends of the mobility in the city of Barcelona. In Universidad de Oviedo.

Rivas, I., Viana, M., Moreno, T., Pandolfi, M., Amato, F., Reche, C., Bouso, L., Àlvarez-Pedrerol, M., Alastuey, A., Sunyer, J., \& Querol, X. (2014). Child exposure to indoor and outdoor air pollutants in schools in Barcelona, Spain. Environment International, 69, 200-212. https://doi.org/10.1016/j.envint.2014.04.009

Romero, J., \& Escudero, J. (2020). Madrid y Barcelona, las dos grandes dudas para dar el salto el lunes a la fase 1. El Confidencial.

Santos, G., Maoh, H., Potoglou, D., \& Brunn, T. Von. (2013). Factors influencing modal split of commuting journeys in medium-size European cities. Journal of Transport Geography, 30, 127137.

Servei Meteorològic de Catalunya. (2021a). L'avanç del butlletí anual del 2020.

Servei Meteorològic de Catalunya. (2021b). Sèrie climàtica de Barcelona des de 1780. https://www.meteo.cat/wpweb/climatologia/serveis-i-dades-climatiques/serie-climaticahistorica-de-barcelona/

Seto, K. C., Dhakal, S., Bigio, A., Blanco, H., Delgado, G. C., Dewar, D., Huang, L., Inaba, A., Kansal, A., Lwasa, S., McMahon, J., Müller, D. B., Murakami, J., Nagendra, H., \& Ramaswami, A. (2014). Human Settlements, Infrastructure, and Spatial Planning. In Climate Change 2014: Mitigation of Climate Change. Contribution of Working Group III to the Fifth Assessment Report of the Intergovernmental Panel on Climate Change (pp. 923-1000).

Spain in English. (2020). Lifting of lockdown in Spain - full details of all phases for all regions. https://www.spainenglish.com/2020/06/18/lifting-lockdown-spain-full-details-phases/

StatBank Denmark. (2020a). Area 1. January by region and time. https://www.statbank.dk/BY1

StatBank Denmark. (2020b). Population 1. January by urban and rural areas and time. https://www.statbank.dk/BY1

Szolnoki, G., \& Hoffmann, D. (2013). Online, face-to-face and telephone surveys - Comparing 
Behavioural changes in urban mobility in Barcelona due to the COVID-19 pandemic and its impact on air pollution and greenhouse gas emissions

different sampling methods in wine consumer research. Wine Economics and Policy, 2(2), 5766. https://doi.org/10.1016/j.wep.2013.10.001

Tirachini, A., \& Cats, O. (2020). COVID-19 and public transportation: Current assessment, prospects, and research needs. Journal of Public Transportation, 22(1), 1-34. https://doi.org/10.5038/2375-0901.22.1.1

Tobías, A., Carnerero, C., Reche, C., Massagué, J., Via, M., Minguillón, M. C., Alastuey, A., \& Querol, X. (2020). Changes in air quality during the lockdown in Barcelona (Spain) one month into the SARS-CoV-2 epidemic. Science of the Total Environment, 726. https://doi.org/10.1016/j.scitotenv.2020.138540

Transport for London. (2021). Hire a Santander cycle in London. https://tfl.gov.uk/modes/cycling/santander-cycles

Transports Metropolitans de Barcelona. (2020). Memòria de sostenibilitat de Transports Metropolitans de Barcelona 2019.

UN data. (2010). World Meteorological Organization Standard Normals - Sunshine. http://data.un.org/Data.aspx?d=CLINO\&f=ElementCode\%3A15

Urra, S., Silvia Ayuso, A., Carbajosa, F., Sánchez, Guillermo Abril, R. de M., \& Torrado, S. (2020, November 6). Bike lanes: How cities across the world are responding to the pandemic. EL PAIS.

Vilaseró, M. (2020a, June 4). Barcelona y Madrid pasarán el lunes a la fase 2 y media España entrará en la 3. El Periodico.

Vilaseró, M. (2020b, June 17). Barcelona y Lleida pasan a fase 3. El Periódico.

Walters, K., Christakis, D. A., \& Wright, D. R. (2018). Are Mechanical Turk worker samples representative of health status and health behaviors in the U.S.? PLOS ONE, 13(6), 1-10. https://doi.org/10.1371/journal.pone.0198835

World Air Quality Index. (2021). World's Air Pollution: Real-time Air Quality Index. https://waqi.info/\#/c/29.447/3.779/3z

World Health Organization. (2005). WHO Air quality guidelines for particulate matter, ozone, nitrogen dioxide and sulfur dioxide: Global update 2005 (pp. 1-21). https://doi.org/10.1016/00046981(88)90109-6

World Health Organization. (2021). Air pollution. https://www.who.int/health-topics/airpollution\#tab=tab_2 
Behavioural changes in urban mobility in Barcelona due to the COVID-19 pandemic and its impact on air pollution and greenhouse gas emissions

Corinna Peters

\section{Appendix}

\section{Questionnaire online survey}

\section{Encuesta sobre el comportamiento de movilidad en Barcelona}

La presente encuesta tiene como objetivo describir las tendencias del comportamiento de movilidad de las personas en Barcelona durante la pandemia COVID-19. Está dirigida a cualquier persona que circula en Barcelona por lo menos desde enero 2020. Esta encuesta se hace en el contexto de investigación de la Universidad de Barcelona.

A continuación, encontrará una serie de preguntas sobre su comportamiento de movilidad. Solicitamos que sus repuestas sean muy sinceras. Sus respuestas son completamente anónimas. El tiempo para llenar la encuesta es aproximadamente 5-7 minutos.

Cualquier inquietud por favor comunicarla al correo: corinna.c.peters@gmail.com.

Muchas gracias por tomar el tiempo de participar en la encuesta.

1. Cuál es su código postal?

2. ANTES de la pandemia COVID-19 (antes de Marzo 2020), cuantas veces por semana en promedio utilizaba usted los siguientes modos de transporte - incluyendo viajes por el trabajo y cualquier otro tipo de viaje (ida y vuelta cuenta como un viaje)?

\begin{tabular}{|l|l|l|l|l|}
\hline & ninguna vez & 1 a 2 veces & 2 a 5 veces & más de 5 veces \\
\hline Metro & & & & \\
\hline Bus & & & & \\
\hline RENFE o FGC & & & & \\
\hline Propia bicicleta & & & & \\
\hline $\begin{array}{l}\text { Bicicleta de 'Bicing' (uso compartido } \\
\text { de bicicletas) }\end{array}$ & & & & \\
\hline Patinete eléctrico & & & & \\
\hline Caminando & & & & \\
\hline Coche particular & & & & \\
\hline Moto & & & & \\
\hline Scooter eléctrico & & & & \\
\hline Otros & & & & \\
\hline
\end{tabular}


Universidad de Barcelona

Behavioural changes in urban mobility in Barcelona due to the COVID-19 pandemic and its impact on air pollution and greenhouse gas emissions

Corinna Peters

3. ANTES de la pandemia (antes de Marzo 2020), cuanto tiempo viajaba usted de media al día por los siguientes modos de transporte?

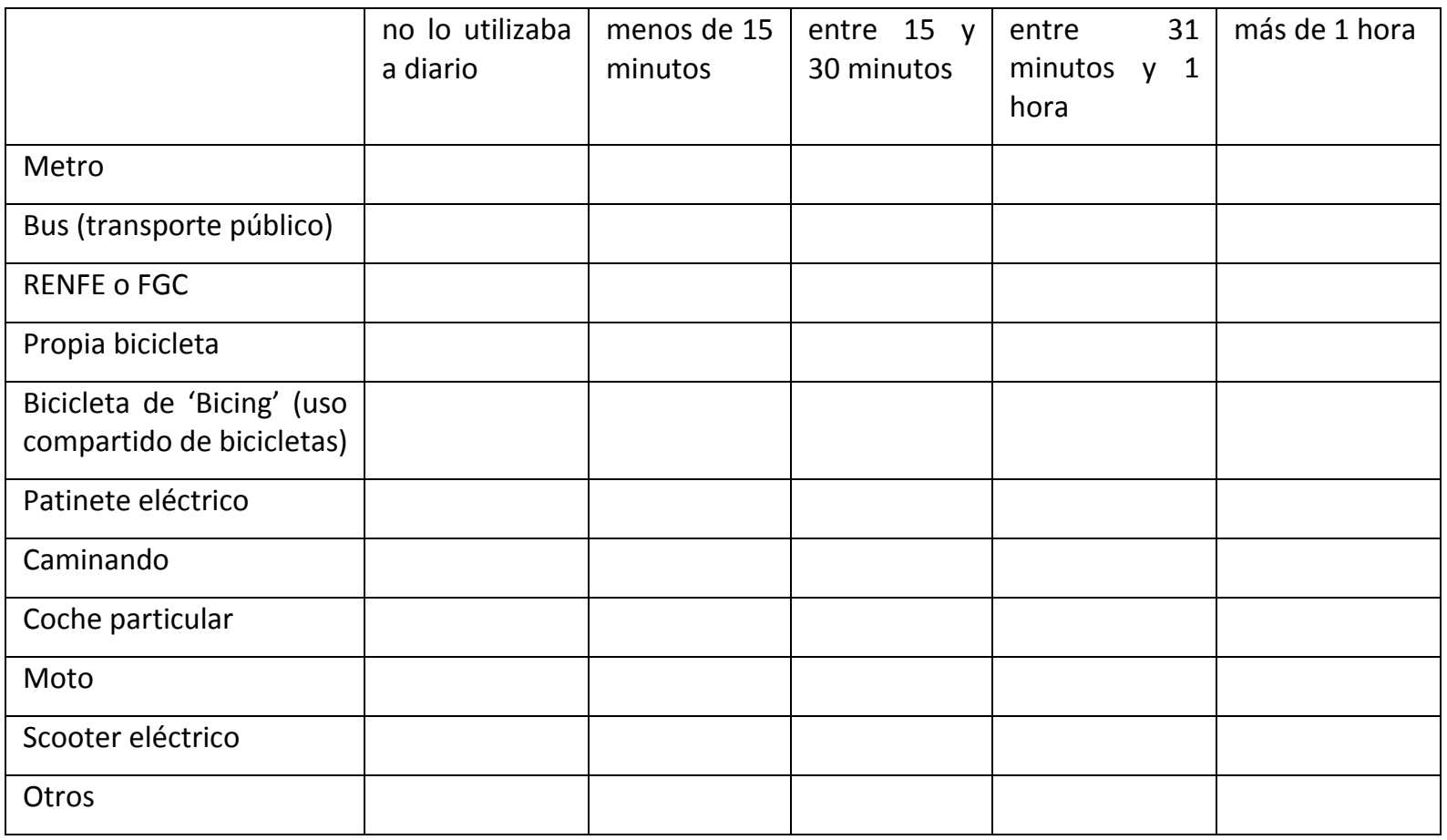

4. En el último mes, cuántas veces por semana utiliza usted los siguientes modos de transporte - incluyendo viajes por el trabajo y cualquier otro tipo de viaje (ida y vuelta cuenta como un viaje)?

\begin{tabular}{|l|l|l|l|l|}
\hline & ninguna vez & 1 a 2 veces & 2 a 5 veces & más de 5 veces \\
\hline Metro & & & & \\
\hline Bus & & & & \\
\hline RENFE o FGC & & & & \\
\hline Propia bicicleta (uso & & & & \\
\hline $\begin{array}{l}\text { Bicicleta de Bicing' } \\
\text { compartido de bicicletas) }\end{array}$ & & & & \\
\hline Patinete eléctrico & & & & \\
\hline Caminando & & & & \\
\hline Coche particular & & & & \\
\hline Moto & & & & \\
\hline Scooter eléctrico & & & \\
\hline Otros & & & \\
\hline
\end{tabular}


Universidad de Barcelona

Behavioural changes in urban mobility in Barcelona due to the COVID-19 pandemic and its impact on air pollution and greenhouse gas emissions

Corinna Peters

5. En el último mes, cuánto tiempo viaja usted de media al día por los siguientes modos de transporte?

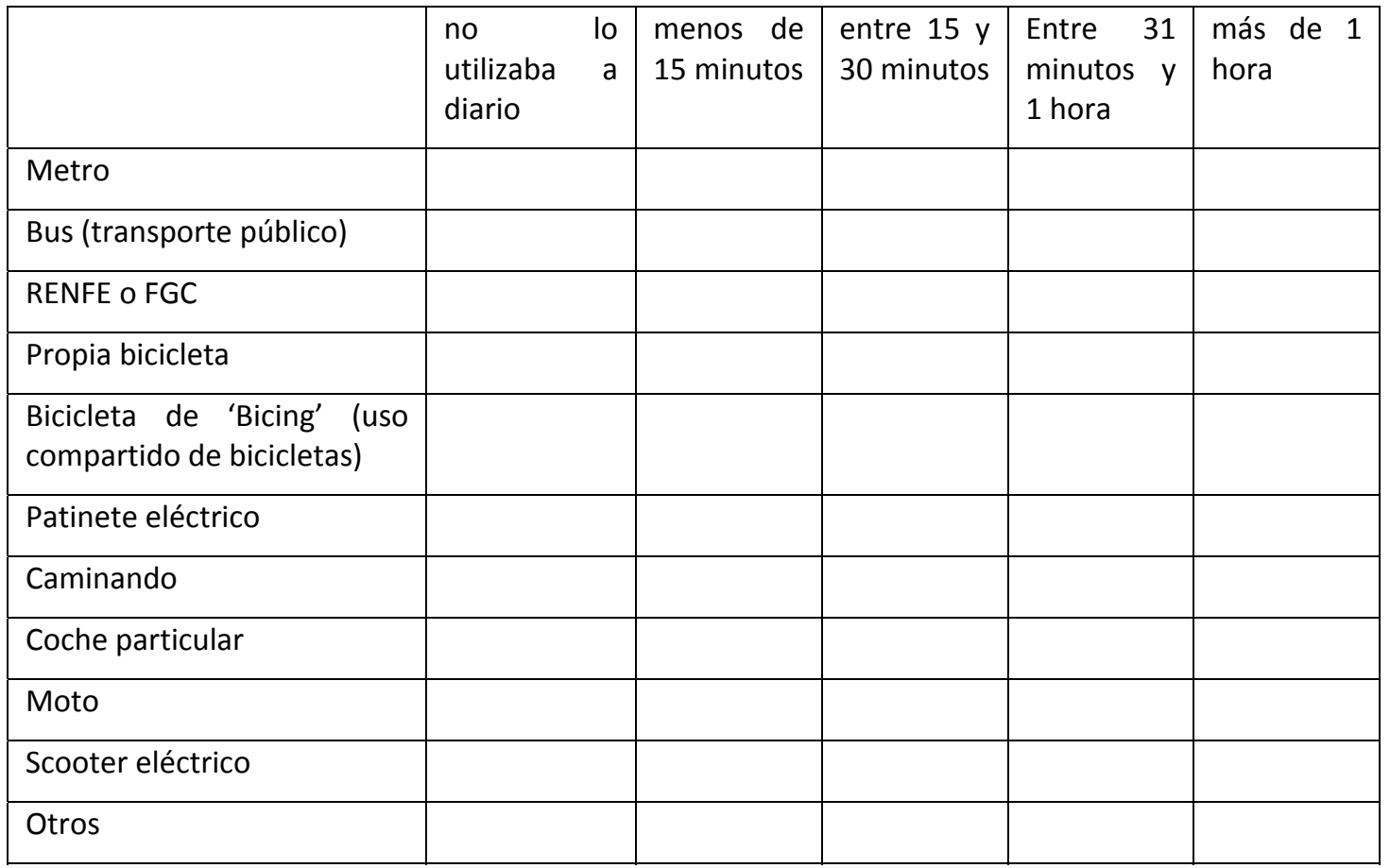

6. Si usted ha cambiado su comportamiento de movilidad durante la pandemia (desde marzo 2020), por qué?

No he cambiado mi comportamiento

No quiero arriesgar contagiarme con COVID No quiero arriesgar contagiar otros con COVID

Porque estudio / trabajo (más) desde casa ahora

Porque los nuevos horarios del transporte público no me van bien

Otras razones 
Universidad de Barcelona

Behavioural changes in urban mobility in Barcelona due to the COVID-19 pandemic and its impact on air pollution and greenhouse gas emissions

Corinna Peters

7. En general, para usted cuales son los factores más importantes para elegir un modo de transporte? Elige hasta 3 aspectos.

Que sea práctico (p. ej. que le deje en la puerta o casi)

Que sea rápido

Que puedo ser independiente (de horarios, estaciones, etc.)

Que sea fiable (puntual, calculable etc.)

Que tenga menos impacto en el clima y el medio ambiente

Que sea económico

Por hábito/costumbre

Que sea seguro

Que hago ejercicio

Que tenga bajo riesgo de contagio con COVID-19

Que me dé tiempo a hacer otras cosas (hacer llamadas, leer, trabajar etc.)

Otras razones

8. Porqué NO va en la bicicleta (más frecuentemente)?

No tengo una bicicleta

No estoy de alta en 'Bicing'

No hay una estación de Bicing cerca

No voy en bici, si no hay bicicletas en la estación de Bicing cerca No voy en bici, si la estación de Bicing del destino suele ser llena

No voy en bici, si la estación de Bicing suele estar vacía cuando quiero volver No voy en bici, si el clima me parece mal (frío, lluvia, calor etc.)

No voy en bici, si no tengo un lugar seguro donde dejar la bicicleta

No me siento segura/o con la bicicleta por la ciudad al lado de coches

No voy en bici, si los caminos que hago me parecen muy largos

No voy en bici, si tengo cosas a transportar / llevar y me parece incomodo en bicicleta

No puedo andar en bicicleta por razones de salud

Otras razones 
Universidad de Barcelona

Behavioural changes in urban mobility in Barcelona due to the COVID-19 pandemic and its impact on air pollution and greenhouse gas emissions

Corinna Peters

9. Porqué usted NO camina más frecuentemente en vez de utilizar otro modo de transporte?

No voy caminando, si el clima me parece mal (frío, lluvia, calor etc.)

No me siento cómoda/o al lado de coches

No me siento segura/o caminando en ciertos barrios

$\mathrm{N}$ voy caminando, si el viaje me parece muy largo para andar caminando

No voy caminando, si tengo cosas a transportar / llevar y me parece incomodo llevarlas caminando

No puedo andar caminando por razones de salud

Otras razones

10. Cómo cree que su comportamiento será cuando la pandemia termine respecto a los siguientes modos de transporte? Creo que utilizaré el modo de transporte...

\begin{tabular}{|l|l|l|l|}
\hline & $\begin{array}{l}\text { Igual que antes de } \\
\text { la pandemia (antes } \\
\text { de marzo 2020) }\end{array}$ & $\begin{array}{l}\text { Más que antes de } \\
\text { la pandemia (antes } \\
\text { de marzo 2020) }\end{array}$ & $\begin{array}{l}\text { Menos que antes } \\
\text { de la pandemia } \\
\text { (antes de marzo } \\
\text { 2020) }\end{array}$ \\
\hline Metro & & & \\
\hline Bus & & & \\
\hline RENFE o FGC & & & \\
\hline Propia bicicleta & & & \\
\hline $\begin{array}{l}\text { Bicicleta de 'Bicing' (uso compartido } \\
\text { de bicicletas) }\end{array}$ & & & \\
\hline Patinete eléctrico & & & \\
\hline Caminando & & & \\
\hline Coche particular & & & \\
\hline Moto & & & \\
\hline Scooter eléctrico & & & \\
\hline Otros & & & \\
\hline
\end{tabular}


Universidad de Barcelona

Behavioural changes in urban mobility in Barcelona due to the COVID-19 pandemic and its impact on air pollution and greenhouse gas emissions

Corinna Peters

11. En lo siguiente le pide responder si está de acuerdo con las siguientes declaraciones. Porfavor llena cada línea.

\begin{tabular}{|l|l|l|l|l|l|}
\hline & $\begin{array}{l}\text { Completamente } \\
\text { de acuerdo }\end{array}$ & De acuerdo & $\begin{array}{l}\text { NO de } \\
\text { acuerdo }\end{array}$ & $\begin{array}{l}\text { Absolutamente } \\
\text { NO de acuerdo }\end{array}$ & No sé \\
\hline $\begin{array}{l}\text { Me gustaría si se mejorara } \\
\text { el transporte público en } \\
\text { Barcelona. }\end{array}$ & & & & \\
\hline $\begin{array}{l}\text { Me gustaría si hubiera más } \\
\text { carriles bicis en vez de } \\
\text { espacio para coches } \\
\text { (parking y calles) en } \\
\text { Barcelona. }\end{array}$ & & & & & \\
\hline $\begin{array}{l}\text { El Ayuntamiento de } \\
\text { Barcelona debe hacer más } \\
\text { para promover modos de } \\
\text { transporte con menos } \\
\text { impacto negativo en el } \\
\text { medio ambiente }\end{array}$ & & & & & \\
\hline $\begin{array}{l}\text { Me gustaría si hubiera más } \\
\text { espacio para coches en } \\
\text { Barcelona (parking calles). }\end{array}$ & & & & & \\
\hline
\end{tabular}

12. Qué edad tiene?

menos de 18 años

18 - 25 años

26 - 35 años

36 - 45 años

46 - 55 años

56 - 65 años

más de 65 años

13. Con cuál género se identifica?

femenino

masculino

otro 
Universidad de Barcelona

Behavioural changes in urban mobility in Barcelona due to the COVID-19 pandemic and its impact on air pollution and greenhouse gas emissions

Corinna Peters

14. Qué nivel de educación tiene usted?

Estudios primarios

Estudios secundarios

Estudios superiores

15. Cuál ingresos neto tiene usted por mes?

menos de 800 por mes

$800-1500$ EUR

$>1500-3000$ EUR

$>3000-5000$ EUR

$>5000$

prefiero no responder

16. Cuál es su estado de ocupación?

Estudiante

Empleada/-o

Autónomo/-a

Desempleado/-a

Pensionista

17. En qué municipio vive usted?

18. Si usted vive en Barcelona, en qué Distrito vive?

19. Cuál es su Worker ID? Eso sirve como su "completion code" para insertar en el cuadro cuando termine la encuesta 


\section{Results of online survey}

\section{Table 9: Reasons for changing behaviour during the pandemic, question 6.}

Values show the share of participants of the respective social category reporting a given reason for having changed their mobility behaviour. Values are displayed in percent except for the last row which shows the number of participants per category. Cells shaded in grey mark the highest value (most frequently cited reason) for each category.

\begin{tabular}{|c|c|c|c|c|c|c|c|c|c|c|c|c|c|c|c|c|c|c|}
\hline \multirow[t]{2}{*}{ Reasons } & \multicolumn{4}{|l|}{ Age } & \multicolumn{2}{|c|}{ Gender } & \multicolumn{4}{|c|}{ Income (monthly net in EUR) } & \multicolumn{4}{|c|}{ Occupation } & \multicolumn{2}{|c|}{ Residence } & \multicolumn{2}{|c|}{ Education } \\
\hline & $18-25$ & $26-35$ & $36-45$ & $>45$ & Man & Woman & $<800$ & $\begin{array}{l}800- \\
1500\end{array}$ & $>1500$ & $\begin{array}{l}\text { No } \\
\text { Response }\end{array}$ & Student & Employee & $\begin{array}{l}\text { Inde- } \\
\text { pendent }\end{array}$ & $\begin{array}{l}\text { Unem- } \\
\text { ployed }\end{array}$ & Other & $\begin{array}{l}\text { Barce- } \\
\text { lona } \\
\text { (city) }\end{array}$ & $\begin{array}{l}\text { Secon- } \\
\text { dary }\end{array}$ & Tertiary \\
\hline \begin{tabular}{ll|} 
Don't & want to \\
risk & infecting \\
myself &
\end{tabular} & 55 & 63 & 77 & 63 & 61 & 72 & 54 & 66 & 66 & 64 & 50 & 71 & 62 & 57 & 69 & 62 & 33 & 68 \\
\hline $\begin{array}{ll}\text { Don't } & \text { want to } \\
\text { risk } & \text { infecting } \\
\text { others } & \end{array}$ & 36 & 29 & 41 & 63 & 34 & 41 & 62 & 37 & 31 & 21 & 35 & 36 & 54 & 14 & 43 & 32 & 25 & 38 \\
\hline $\begin{array}{lr}\text { work } & \text { /study } \\
\text { (more) } & \text { from } \\
\text { home } & \end{array}$ & 50 & 48 & 41 & 13 & 40 & 55 & 38 & 55 & 37 & 36 & 45 & 44 & 31 & 57 & 57 & 37 & 42 & 44 \\
\hline $\begin{array}{l}\text { Timetables of } \\
\text { public transport } \\
\text { don't suit me } \\
\text { well }\end{array}$ & 0 & 4 & 0 & 0 & 1 & 3 & 8 & 3 & 0 & 0 & 0 & 0 & 15 & 0 & 3 & 2 & 8 & 1 \\
\hline Other reasons & 0 & 0 & 5 & 0 & 1 & 0 & 0 & 0 & 0 & 7 & 0 & 0 & 8 & 0 & 3 & 0 & 0 & 1 \\
\hline \begin{tabular}{ll|} 
No. & of \\
respondents
\end{tabular} & 22 & 48 & 22 & 8 & 70 & 29 & 13 & 38 & 35 & 14 & 20 & 59 & 13 & 7 & 35 & 65 & 12 & 88 \\
\hline
\end{tabular}


Behavioural changes in urban mobility in Barcelona due to the COVID-19 pandemic and its impact on air pollution and greenhouse gas emissions

Corinna Peters

Table 10: Reasons for not cycling more often, question 8.

Values show the share of participants of the respective social category reporting a given reason for not cycling (more often). Values are displayed in percent except for the last row which shows the number of participants per category. Cells shaded in grey mark the highest value (most frequently cited reason) for each category.

\begin{tabular}{|c|c|c|c|c|c|c|c|c|c|c|c|c|c|c|c|c|c|c|c|}
\hline \multirow[t]{2}{*}{ Reasons } & \multicolumn{4}{|l|}{ Age } & \multicolumn{2}{|c|}{ Gender } & \multicolumn{4}{|c|}{ Income (monthly net in EUR) } & \multicolumn{4}{|c|}{ Occupation } & \multicolumn{2}{|c|}{ Education } & \multicolumn{2}{|c|}{ Residence } & \multirow[t]{2}{*}{$A l l$} \\
\hline & $18-25$ & 26-35 & $36-45$ & $>45$ & Man & Woman & $<800$ & $\begin{array}{l}800- \\
1500\end{array}$ & $>1500$ & $\begin{array}{l}\text { No } \\
\text { Response }\end{array}$ & Student & Employee & \begin{tabular}{|l|} 
Inde- \\
pendent
\end{tabular} & $\begin{array}{l}\text { Unem- } \\
\text { ployed }\end{array}$ & $\begin{array}{l}\text { Secon- } \\
\text { dary }\end{array}$ & Tertiary & Other & $\begin{array}{l}\text { Barce- } \\
\text { lona }\end{array}$ & \\
\hline Don't have a bike & 50 & 38 & 36 & 38 & 43 & 31 & 54 & 34 & 34 & 57 & 45 & 37 & 23 & 86 & 67 & 36 & 37 & 42 & 40 \\
\hline Bad weather & 32 & 31 & 23 & 38 & 26 & 41 & 46 & 32 & 29 & 14 & 30 & 25 & 46 & 29 & 17 & 32 & 29 & 31 & 30 \\
\hline No 'Bicing' subscription & 14 & 23 & 32 & 25 & 21 & 24 & 31 & 21 & 29 & 7 & 35 & 19 & 31 & 14 & 17 & 24 & 23 & 23 & 23 \\
\hline $\begin{array}{l}\begin{array}{l}\text { Feeling unsafe next to } \\
\text { cars }\end{array} \\
\end{array}$ & 18 & 29 & 14 & 13 & 24 & 17 & 23 & 16 & 31 & 14 & 15 & 24 & 15 & 43 & 17 & 23 & 20 & 23 & 22 \\
\hline Having to carry things & 27 & 15 & 23 & 25 & 17 & 28 & 31 & 18 & 17 & 21 & 15 & 15 & 46 & 14 & 17 & 20 & 29 & 15 & 20 \\
\hline Long distance & 9 & 19 & 27 & 25 & 13 & 34 & 15 & 21 & 23 & 7 & 5 & 20 & 23 & 29 & 8 & 20 & 23 & 17 & 19 \\
\hline No safe parking space & 18 & 15 & 5 & 13 & 14 & 10 & 31 & 18 & 3 & 7 & 15 & 10 & 15 & 29 & 8 & 14 & 11 & 14 & 13 \\
\hline $\begin{array}{l}\text { No 'Bicing' station close } \\
\text { by }\end{array}$ & 5 & 2 & 9 & 25 & 4 & 10 & 0 & 11 & 6 & 0 & 5 & 8 & 0 & 0 & 0 & 7 & 14 & 2 & 6 \\
\hline $\begin{array}{l}\text { Don't go by bike, if the } \\
\text { 'Bicing' station is regularly } \\
\text { full at the destination }\end{array}$ & 5 & 6 & 0 & 13 & 3 & 10 & 0 & 5 & 9 & 0 & 0 & 7 & 0 & 14 & 0 & 6 & 3 & 6 & 5 \\
\hline $\begin{array}{l}\text { I don't go by bike, if there } \\
\text { is no bike at 'Bicing' } \\
\text { stations close by }\end{array}$ & 0 & 8 & 0 & 13 & 1 & 14 & 0 & 3 & 11 & 0 & 0 & 7 & 0 & 14 & 0 & 6 & 3 & 6 & 5 \\
\hline $\begin{array}{l}\text { No bikes in 'Bicing' station } \\
\text { when I want to go back } \\
\text { home }\end{array}$ & 5 & 4 & 0 & 0 & 1 & 7 & 8 & 0 & 6 & 0 & 5 & 3 & 0 & 0 & 0 & 3 & 3 & 3 & 3 \\
\hline Health reasons & 0 & 2 & 0 & 0 & 0 & 3 & 0 & 3 & 0 & 0 & 5 & 0 & 0 & 0 & 0 & 1 & 0 & 2 & 1 \\
\hline Other reasons & 0 & 6 & 18 & 0 & 6 & 10 & 9 & 8 & 3 & 14 & 0 & 10 & 0 & 28 & 0 & 8 & 11 & 5 & 7 \\
\hline No. of respondents & 22 & 48 & 22 & 8 & 70 & 29 & 13 & 38 & 35 & 14 & 20 & 59 & 13 & 7 & 35 & 65 & 12 & 88 & 100 \\
\hline
\end{tabular}


Behavioural changes in urban mobility in Barcelona due to the COVID-19 pandemic and its impact on air pollution and greenhouse gas emissions

Corinna Peters

Table 11: Reasons for not walking (more often), question 9.

Values show the share of participants of the respective social category reporting a given reason for not walking (more often). Values are displayed in percent except for the last row which shows the number of participants per category. Cells shaded in grey mark the highest value (most frequently cited reason) for each category.

\begin{tabular}{|c|c|c|c|c|c|c|c|c|c|c|c|c|c|c|c|c|c|c|c|}
\hline & \multicolumn{4}{|c|}{ Age } & \multicolumn{2}{|c|}{ Gender } & \multicolumn{4}{|c|}{ Income (monthly net in EUR) } & \multicolumn{4}{|c|}{ Occupation } & \multicolumn{2}{|c|}{ Education } & \multicolumn{2}{|c|}{ Residence } & \multirow[t]{2}{*}{ All } \\
\hline & $18-25$ & $26-35$ & $36-45$ & $>45$ & Man & Woman & $<800$ & $800-1500$ & $>1500$ & \begin{tabular}{|c|} 
No \\
Response \\
\end{tabular} & Student & Employee & \begin{tabular}{|c|}
$\begin{array}{c}\text { Inde- } \\
\text { pendent }\end{array}$ \\
\end{tabular} & $\begin{array}{l}\text { Unem- } \\
\text { ployed }\end{array}$ & Secondary & Tertiary & Other & $\begin{array}{c}\text { Barce- } \\
\text { lona }\end{array}$ & \\
\hline Long distance & 55 & 54 & 50 & 38 & 49 & 62 & 31 & 55 & 51 & 64 & 55 & 46 & 69 & 57 & 33 & 55 & 66 & 45 & 52 \\
\hline Bad weather & 45 & 40 & 41 & 75 & 41 & 48 & 38 & 47 & 46 & 36 & 45 & 44 & 54 & 29 & 50 & 43 & 34 & 49 & 44 \\
\hline $\begin{array}{l}\text { Having things } \\
\text { to carry }\end{array}$ & 41 & 38 & 32 & 38 & 33 & 48 & 46 & 45 & 20 & 50 & 40 & 32 & 46 & 43 & 17 & 40 & 46 & 32 & 37 \\
\hline $\begin{array}{l}\text { Feeling unsafe } \\
\text { in certain parts } \\
\text { of } \mathrm{BCN}\end{array}$ & 32 & 27 & 14 & 25 & 29 & 17 & 23 & 18 & 31 & 29 & 30 & 27 & 15 & 14 & 25 & 25 & 26 & 25 & 25 \\
\hline $\begin{array}{l}\text { Don't feel } \\
\text { comfortable } \\
\text { next to cars }\end{array}$ & 9 & 6 & 0 & 0 & 7 & 0 & 0 & 0 & 9 & 14 & 10 & 3 & 8 & 0 & 0 & 6 & 11 & 2 & 5 \\
\hline Other reasons & 22 & 52 & 22 & 8 & 71 & 32 & 21 & 38 & 38 & 14 & 20 & 61 & 13 & 21 & 35 & 67 & 15 & 90 & 102 \\
\hline Health reasons & 0 & 2 & 0 & 0 & 0 & 3 & 0 & 3 & 0 & 0 & 5 & 0 & 0 & 0 & 0 & 1 & 0 & 2 & 1 \\
\hline \begin{tabular}{|l|} 
No. of \\
respondents
\end{tabular} & 22 & 48 & 22 & 8 & 70 & 29 & 13 & 38 & 35 & 14 & 20 & 59 & 13 & 7 & 35 & 65 & 12 & 88 & 100 \\
\hline
\end{tabular}


Table 12: Wishes for improvement in urban mobility, question 11.

Values show the share of participants of the respective social category reporting a given preference for urban mobility measures. Values are displayed in percent except for the last row which shows the number of participants per category.

\begin{tabular}{|c|c|c|c|c|c|c|c|c|c|c|c|c|c|c|c|c|c|c|c|c|}
\hline & & \multicolumn{4}{|c|}{ Age } & \multicolumn{2}{|c|}{ Gender } & \multicolumn{4}{|c|}{ Income (monthly net in EURO) } & \multicolumn{4}{|c|}{ Occupation } & \multicolumn{2}{|c|}{ Education } & \multicolumn{2}{|c|}{ Residence } & \multirow[t]{2}{*}{ All } \\
\hline & & $18-25$ & $26-35$ & $36-45$ & $>45$ & Man & Woman & $<800$ & $800-1500$ & $>1500$ & $\begin{array}{c}\text { No } \\
\text { Response }\end{array}$ & Student & $\begin{array}{c}\text { Em- } \\
\text { ployee }\end{array}$ & $\begin{array}{c}\text { Inde- } \\
\text { pendent }\end{array}$ & $\begin{array}{l}\text { Unem- } \\
\text { ployed }\end{array}$ & $\begin{array}{c}\text { Secon- } \\
\text { dary }\end{array}$ & Tertiary & Other & $\begin{array}{c}\text { Barce- } \\
\text { lona }\end{array}$ & \\
\hline \multirow{5}{*}{$\begin{array}{l}\text { improve } \\
\text { public } \\
\text { transport }\end{array}$} & strongly agree & 45 & 50 & 55 & 63 & 49 & 55 & 38 & 42 & 63 & 57 & 55 & 51 & 54 & 29 & 58 & 50 & 66 & 43 & 51 \\
\hline & agree & 50 & 42 & 41 & 13 & 41 & 41 & 38 & 50 & 34 & 36 & 35 & 44 & 31 & 57 & 25 & 43 & 26 & 49 & 41 \\
\hline & disagree & 5 & 2 & 5 & 25 & 7 & 0 & 15 & 3 & 3 & 7 & 5 & 3 & 8 & 14 & 8 & 5 & 6 & 5 & 5 \\
\hline & strongly disagree & 0 & 0 & 0 & 0 & 0 & 0 & 0 & 0 & 0 & 0 & 0 & 0 & 0 & 0 & 0 & 0 & 0 & 0 & 0 \\
\hline & I don't know & 0 & 6 & 0 & 0 & 3 & 3 & 8 & 5 & 0 & 0 & 5 & 2 & 8 & 0 & 8 & 2 & 3 & 3 & 3 \\
\hline \multirow{5}{*}{$\begin{array}{l}\text { create more } \\
\text { bike lanes } \\
\text { instead of } \\
\text { car space }\end{array}$} & strongly agree & 18 & 40 & 50 & 38 & 34 & 45 & 23 & 29 & 46 & 50 & 30 & 36 & 46 & 43 & 42 & 36 & 37 & 37 & 37 \\
\hline & agree & 36 & 44 & 14 & 38 & 39 & 28 & 38 & 42 & 26 & 36 & 40 & 34 & 31 & 43 & 25 & 36 & 37 & 34 & 35 \\
\hline & disagree & 27 & 0 & 14 & 13 & 10 & 10 & 23 & 13 & 6 & 0 & 10 & 12 & 8 & 0 & 17 & 9 & 6 & 12 & 10 \\
\hline & strongly disagree & 14 & 4 & 14 & 0 & 9 & 3 & 8 & 5 & 11 & 7 & 15 & 8 & 0 & 0 & 0 & 9 & 9 & 8 & 8 \\
\hline & I don't know & 5 & 13 & 9 & 13 & 9 & 14 & 8 & 11 & 11 & 7 & 5 & 10 & 15 & 14 & 17 & 9 & 11 & 9 & 10 \\
\hline \multirow{4}{*}{$\begin{array}{l}\text { create more } \\
\text { pedestrian } \\
\text { areas } \\
\text { instead of } \\
\text { car space }\end{array}$} & strongly agree & 23 & 42 & 55 & 50 & 36 & 55 & 23 & 39 & 46 & 50 & 40 & 42 & 38 & 29 & 42 & 41 & 43 & 40 & 41 \\
\hline & agree & 27 & 48 & 14 & 13 & 36 & 28 & 31 & 42 & 29 & 21 & 30 & 34 & 31 & 43 & 33 & 33 & 17 & 42 & 33 \\
\hline & disagree & 27 & 2 & 23 & 25 & 16 & 7 & 31 & 5 & 17 & 14 & 15 & 12 & 15 & 29 & 0 & 16 & 17 & 12 & 14 \\
\hline & strongly disagree & 14 & 2 & 9 & 13 & 10 & 0 & 0 & 5 & 9 & 14 & 10 & 7 & 8 & 0 & 8 & 7 & 11 & 5 & 7 \\
\hline \multirow{5}{*}{$\begin{array}{l}\text { promote } \\
\text { climate } \\
\text { friendly } \\
\text { mobility }\end{array}$} & strongly agree & 23 & 46 & 55 & 50 & 37 & 59 & 15 & 45 & 51 & 43 & 35 & 44 & 54 & 29 & 42 & 43 & 43 & 43 & 43 \\
\hline & agree & 23 & 44 & 23 & 38 & 40 & 21 & 38 & 37 & 34 & 21 & 15 & 37 & 38 & 57 & 33 & 34 & 43 & 29 & 34 \\
\hline & disagree & 32 & 2 & 5 & 13 & 9 & 14 & 23 & 13 & 3 & 7 & 30 & 7 & 0 & 0 & 8 & 10 & 0 & 15 & 10 \\
\hline & strongly disagree & 9 & 2 & 5 & 0 & 6 & 0 & 8 & 0 & 6 & 7 & 5 & 5 & 0 & 0 & 8 & 3 & 3 & 5 & 4 \\
\hline & I don't know & 14 & 6 & 14 & 0 & 9 & 7 & 15 & 5 & 6 & 21 & 15 & 7 & 8 & 14 & 8 & 9 & 11 & 8 & 9 \\
\hline \multirow{5}{*}{$\begin{array}{l}\text { create more } \\
\text { car space }\end{array}$} & strongly agree & 14 & 19 & 27 & 13 & 16 & 24 & 8 & 13 & 26 & 29 & 10 & 22 & 15 & 29 & 8 & 20 & 26 & 15 & 19 \\
\hline & agree & 23 & 25 & 23 & 13 & 26 & 17 & 31 & 24 & 20 & 21 & 25 & 24 & 31 & 0 & 17 & 24 & 20 & 25 & 23 \\
\hline & disagree & 32 & 29 & 23 & 38 & 31 & 24 & 38 & 29 & 29 & 21 & 30 & 27 & 31 & 43 & 25 & 30 & 29 & 29 & 29 \\
\hline & strongly disagree & 18 & 15 & 23 & 38 & 17 & 24 & 15 & 16 & 23 & 21 & 25 & 17 & 15 & 14 & 33 & 17 & 11 & 23 & 19 \\
\hline & I don't know & 14 & 13 & 5 & 0 & 10 & 10 & 8 & 18 & 3 & 7 & 10 & 10 & 8 & 14 & 17 & 9 & 14 & 8 & 10 \\
\hline \multicolumn{2}{|c|}{ No. of respondents } & 22 & 48 & 22 & 8 & 70 & 29 & 13 & 38 & 35 & 14 & 20 & 59 & 13 & 7 & 35 & 65 & 12 & 88 & 100 \\
\hline
\end{tabular}


Behavioural changes in urban mobility in Barcelona due to the COVID-19 pandemic and its impact on air pollution and greenhouse gas emissions

\section{Results of regression analysis}

A regression analysis was conducted to estimate which factors could help explain the reported increase of usage of a certain means of transport. Eight regressions were estimated using Ordinary Least Squares (OLS), one for each one of the considered modes of transports, namely Metro, Bus, RENFE or other railways, own bicycle, shared bicycle, walk, electric scooter (patinete eléctrico), and car. The dependent variables are an increase in usage of these means of transport. The independent variables are gender, age, occupation, education level, income level, whether the respondent uses a car and whether the respondent is a resident of Barcelona.

However, limited variation of the data does not allow for estimating a statistical model with satisfying performance. Results were mostly statistical insignificant. Low variability could imply that participants across the social categories share similar ideas and preferences regarding urban mobility. One factor that was statistically significant and positively correlated with cycling more often was being within the age group of 36 to 45 . Results are presented in Table 13 below.

To attempt to address the issue of low variability, other models were considered, namely a logit and a probit model, but further observations were omitted, reducing the possibility for statistical inference. Thus, the results are presented using an OLS model. 
Universidad de Barcelona

Behavioural changes in urban mobility in Barcelona due to the COVID-19 pandemic and its impact on air pollution and greenhouse gas emissions

Corinna Peters

Table 13: Results of OLS model.

\begin{tabular}{|c|c|c|c|c|c|c|c|c|c|}
\hline & & Metro & Bus & RENFE & $\begin{array}{c}\text { Own } \\
\text { bicycle }\end{array}$ & $\begin{array}{l}\text { Shared } \\
\text { bicycle }\end{array}$ & Walk & $\begin{array}{l}\text { Electric } \\
\text { Scooter } \\
\text { (patinete) }\end{array}$ & Car \\
\hline \multirow{2}{*}{ Gender } & \multirow[t]{2}{*}{ Woman } & 0.02 & -0.03 & 0.02 & 0.01 & -0.01 & -0.05 & -0.08 & 0.06 \\
\hline & & $(0.52)$ & $(-0.56)$ & $(0.40)$ & $(0.16)$ & $(-0.08)$ & $(-0.64)$ & $(-1.50)$ & $(0.68)$ \\
\hline \multirow{6}{*}{ Age } & \multirow[t]{2}{*}{$26-35$} & 0.01 & -0.06 & -0.01 & 0.10 & -0.09 & 0.10 & -0.01 & 0.21 \\
\hline & & $(0.31)$ & $(-0.95)$ & $(-0.33)$ & $(1.02)$ & $(-0.63)$ & $(0.86)$ & $(-0.09)$ & $(1.72)$ \\
\hline & \multirow[t]{2}{*}{$36-45$} & 0.03 & -0.00 & 0.11 & $0.50 * * *$ & -0.16 & 0.27 & 0.08 & 0.07 \\
\hline & & $(0.71)$ & $(-0.00)$ & $(1.39)$ & $(3.52)$ & $(-1.07)$ & $(1.93)$ & $(0.55)$ & $(0.56)$ \\
\hline & \multirow[t]{2}{*}{$>45$} & -0.03 & -0.06 & -0.11 & -0.07 & -0.16 & 0.30 & -0.07 & 0.36 \\
\hline & & $(-1.01)$ & $(-0.92)$ & $(-1.52)$ & $(-0.65)$ & $(-1.12)$ & $(1.65)$ & $(-0.49)$ & $(1.82)$ \\
\hline \multirow{6}{*}{ Occupation } & \multirow[t]{2}{*}{ Employee } & 0.03 & 0.10 & -0.02 & -0.14 & $0.25^{*}$ & 0.18 & 0.14 & -0.01 \\
\hline & & $(1.03)$ & $(1.24)$ & $(-0.49)$ & $(-1.21)$ & $(2.25)$ & $(1.80)$ & $(1.60)$ & $(-0.12)$ \\
\hline & \multirow[t]{2}{*}{ Independent } & 0.01 & 0.06 & 0.22 & 0.07 & 0.16 & -0.14 & 0.05 & 0.04 \\
\hline & & $(0.30)$ & $(0.96)$ & $(1.78)$ & $(0.44)$ & $(1.68)$ & $(-1.61)$ & $(0.38)$ & $(0.27)$ \\
\hline & \multirow[t]{2}{*}{ Unemployed } & -0.01 & 0.13 & 0.12 & -0.18 & 0.23 & -0.14 & 0.09 & $-0.29 *$ \\
\hline & & $(-0.56)$ & $(1.00)$ & $(0.94)$ & $(-1.13)$ & $(1.20)$ & $(-1.65)$ & $(0.42)$ & $(-2.02)$ \\
\hline \multirow{2}{*}{ Education } & \multirow[t]{2}{*}{ Tertiary } & 0.02 & 0.07 & 0.08 & 0.07 & 0.11 & 0.05 & 0.01 & $0.25^{* *}$ \\
\hline & & $(1.24)$ & $(1.49)$ & $(1.60)$ & $(0.80)$ & $(1.96)$ & $(0.46)$ & $(0.05)$ & $(2.90)$ \\
\hline \multirow{15}{*}{ Income } & \multirow[t]{2}{*}{$800-1500$} & 0.01 & -0.20 & 0.03 & 0.00 & -0.10 & -0.08 & -0.05 & -0.09 \\
\hline & & $(0.40)$ & $(-1.71)$ & $(0.49)$ & $(0.04)$ & $(-0.63)$ & $(-0.49)$ & $(-0.31)$ & $(-0.56)$ \\
\hline & \multirow[t]{2}{*}{$>1500$} & 0.03 & -0.19 & 0.07 & -0.05 & -0.11 & -0.15 & -0.06 & -0.17 \\
\hline & & $(0.86)$ & $(-1.50)$ & $(0.78)$ & $(-0.41)$ & $(-0.62)$ & $(-0.84)$ & $(-0.31)$ & $(-0.95)$ \\
\hline & \multirow[t]{2}{*}{ No response } & 0.02 & -0.21 & -0.12 & 0.03 & -0.13 & 0.03 & 0.22 & -0.24 \\
\hline & & $(0.84)$ & $(-1.79)$ & $(-1.50)$ & $(0.19)$ & $(-1.13)$ & $(0.27)$ & $(1.36)$ & $(-1.82)$ \\
\hline & \multirow[t]{2}{*}{ Use car } & -0.03 & -0.04 & -0.05 & 0.11 & -0.00 & -0.04 & -0.07 & 0.16 \\
\hline & & $(-0.57)$ & $(-0.79)$ & $(-0.87)$ & $(1.39)$ & $(-0.00)$ & $(-0.54)$ & $(-1.05)$ & $(1.92)$ \\
\hline & \multirow[t]{2}{*}{ Resid. of BCN } & 0.05 & 0.05 & -0.03 & $0.23 * *$ & 0.08 & 0.01 & 0.03 & -0.16 \\
\hline & & $(1.47)$ & $(1.12)$ & $(-0.67)$ & $(2.94)$ & $(1.25)$ & $(0.09)$ & $(0.34)$ & $(-1.39)$ \\
\hline & Adjusted $R^{2}$ & 0.06 & 0.14 & 0.19 & 0.28 & 0.13 & 0.18 & 0.15 & 0.21 \\
\hline & Observations & 96 & 96 & 96 & 96 & 96 & 96 & 96 & 96 \\
\hline & \multicolumn{9}{|c|}{ t statistics in parentheses, indicating if a variable's significance level is over $95 \%$ if $>1.96$ or $<-1.96$. } \\
\hline & \multicolumn{9}{|c|}{$* p<0.05$ (possibly significant), $* * p<0.01$ (likely significant), $* * * p<0.001$ (statistically significant) } \\
\hline & \multicolumn{9}{|c|}{$\begin{array}{l}\text { Adjusted } R^{2} \text { indicates how well the model fits to explain variability around the mean. } 0 \text { indicates } \\
\text { that the model explains none of the variability of the response data. } 1 \text { indicates that the model } \\
\text { explains all the variability. }\end{array}$} \\
\hline
\end{tabular}


Universidad de Barcelona

Behavioural changes in urban mobility in Barcelona due to the COVID-19 pandemic and its impact on air pollution and greenhouse gas emissions

Corinna Peters

\section{Interview questionnaire for public administration officials of Barcelona}

1) What is your role in the institution?

2) What are the most notable changes in mobility since the pandemic has started?

3) What are the main challenges in urban mobility right now?

4) Which challenges in urban mobility do you foresee once the pandemic is over?

5) What measures has your institution taken (and/or will take) to confront those challenges? 
Behavioural changes in urban mobility in Barcelona due to the COVID-19 pandemic and its impact on air pollution and greenhouse gas emissions

Corinna Peters

\section{Summary of interviews}

1. Interview with City Council of Barcelona

Interviewee: Adrià Gomila (Director of Mobility)

Date of interview: 14.01.2021

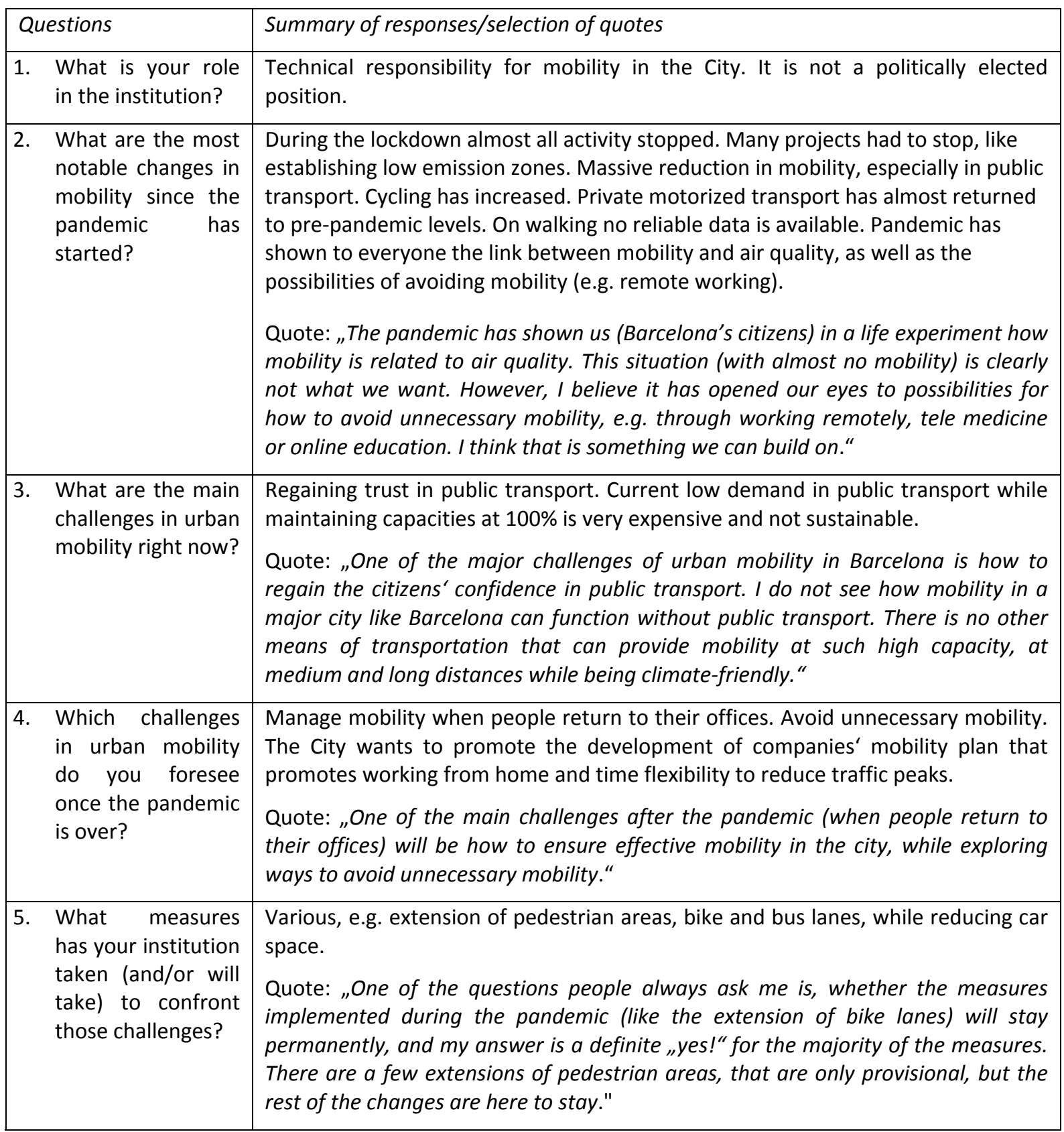

2. Interview with Barcelona's transport authority (ATM) 
Behavioural changes in urban mobility in Barcelona due to the COVID-19 pandemic and its impact on air pollution and greenhouse gas emissions

Interviewees: Director of Mobility (Lluís Alegre) and Head of Mobility Service (Xavier Sanyer)

Date of interview: 18.01.2021

\begin{tabular}{|c|c|}
\hline Question & Summary of responses/selection of quotes \\
\hline $\begin{array}{l}\text { 1. What is your role } \\
\text { in the institution? }\end{array}$ & $\begin{array}{l}\text { Lluís Alegre: Coordination of the planning of public transport, mobility and } \\
\text { transport infrastructure. } \\
\text { Xavier Sanyer: Planning and managing of mobility services. }\end{array}$ \\
\hline $\begin{array}{l}\text { 2. What are the most } \\
\text { notable changes in } \\
\text { mobility since the } \\
\text { pandemic has } \\
\text { started? }\end{array}$ & $\begin{array}{l}\text { Radical reduction in use of public transport. Demand has recovered a bit in the last } \\
\text { months, but it is still at a low level. Private motorized mobility is a bit lower than } \\
\text { pre-pandemic levels. Medium age of people doing online shopping has increased, } \\
\text { due to older citizens, that typically went to stores in person, starting to shop } \\
\text { online. Home office has picked up. }\end{array}$ \\
\hline $\begin{array}{l}\text { W. What are the main } \\
\text { challenges in urban } \\
\text { mobility right now? }\end{array}$ & $\operatorname{Recc}$ \\
\hline $\begin{array}{l}\text { 4. Which challenges } \\
\text { in urban mobility } \\
\text { do you foresee } \\
\text { once the pandemic } \\
\text { is over? }\end{array}$ & $\begin{array}{l}\text { Demand for public transport might stay at lower levels in the short and medium } \\
\text { term. High uncertainty about mobility behaviour. } \\
\text { Quote (Xavier Sanyer): "There is a high uncertainty about how behavioural change } \\
\text { during the pandemic will affect us in the future. Will people go back to their pre- } \\
\text { pandemic habits? Will people work more often from home than before the } \\
\text { pandemic? Will people keep buying most products online? We have to make our } \\
\text { planning under these uncertain conditions without knowing how demand will } \\
\text { develop." }\end{array}$ \\
\hline $\begin{array}{l}\text { 5. What measures } \\
\text { has your institution } \\
\text { taken (and/or will } \\
\text { take) to confront } \\
\text { those challenges? }\end{array}$ & $\begin{array}{l}\text { Various, e.g. doubling the ventilation in metro (in } 3 \text { minutes } 100 \% \text { of air is } \\
\text { exchanged), requiring face masks, keeping up capacity, despite demand reduction, } \\
\text { support companies in drafting their mobility plans etc. } \\
\text { Quote (Lluis Alegre): "We have taken measures to keep people safe and regain } \\
\text { their trust in public transport. For example, we are providing hand sanitizer at } \\
\text { every metro station, we have doubled the ventilation capacity of the metro and we } \\
\text { keep people informed about the occupancy rates. We believe that if we do things } \\
\text { well and communicate them better, we can regain people's trust." }\end{array}$ \\
\hline
\end{tabular}


Behavioural changes in urban mobility in Barcelona due to the COVID-19 pandemic and its impact on air pollution and greenhouse gas emissions

\section{Google Community Mobility Report Barcelona}

With the start of the pandemic Google has published mobility data at community level (Google, 2021). As might have been expected, trips to pharmacies and grocery stores have experienced the least reduction during the strict lockdown in March to May, while trips to retails stores or recreational facilities have reduced the most during these weeks (see Figure 22 below).

Figure 22: Change in mobility by destination, Barcelona, 2020

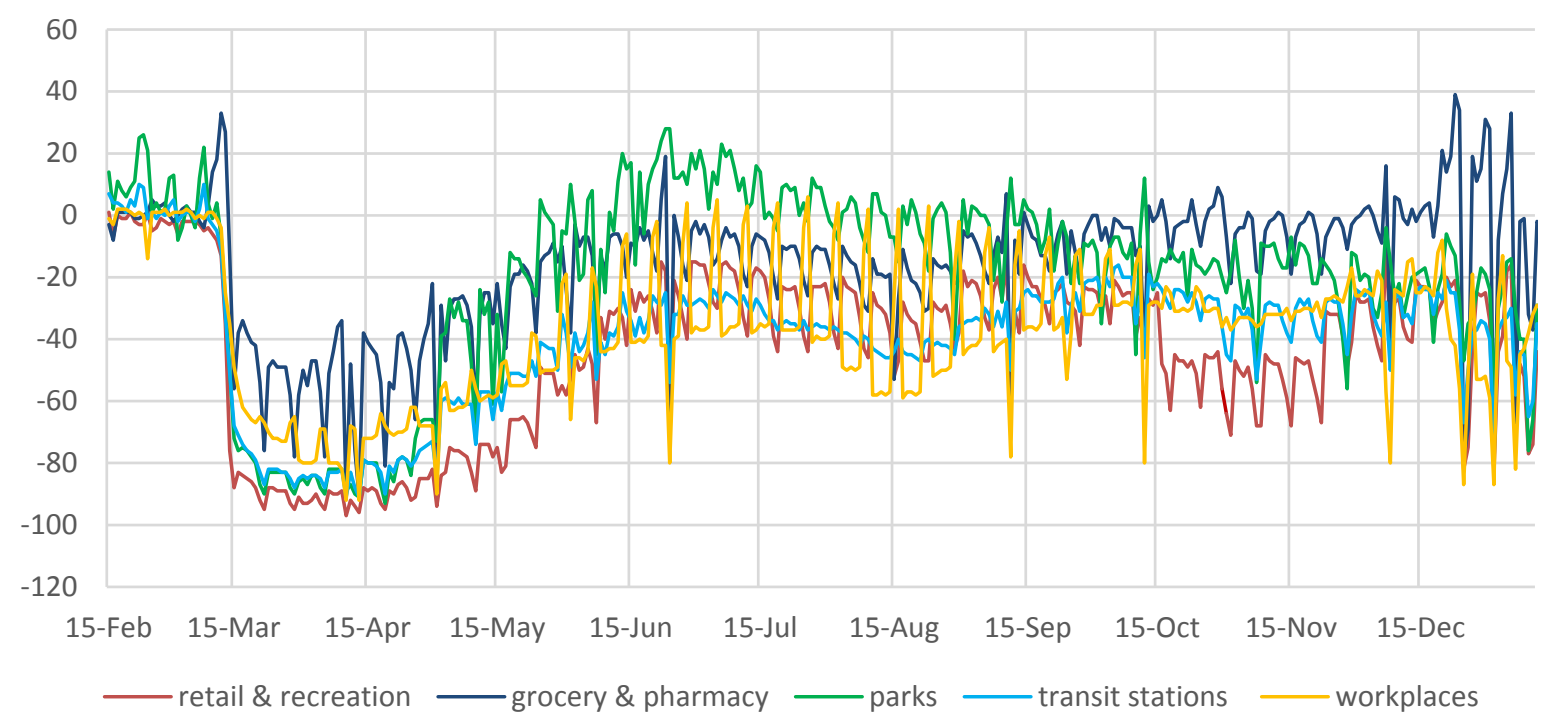

Source: Own illustration based on Google mobility data (Google, 2021).

Note: 1)This data is created with aggregated, anonymized sets of data from google users who have turned on the Location History setting. 2) The data shows how visitors to categorized places change compared to the baseline days. 3) A baseline day represents a normal value for that day of the week. The baseline day is the median value from the 5-week period Jan 3 - Feb 6, 2020. 